\title{
ISSN:2178-8839
}

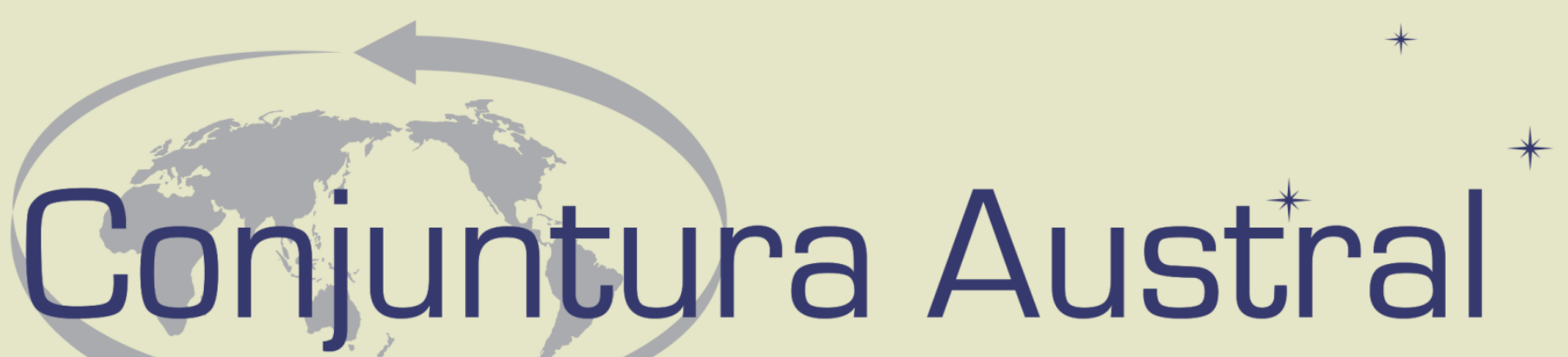

Revista do Núcleo de Estratégia e Relações Internacionais

Programa de Pós-Graduação em Estudos Estratégicos Internacionais/UFRGS

THE PARROT, THE MONKEY AND THE MYTH OF EMULATION OR EXTINCTION IN IR ARÁBIA SAUDITA: SUCESSÃO REAL E INTERVENÇÃO NO IÊMEN POLÍTICA AFRICANA DO BRASIL: MUDANC̣A ENTRE LULA E DILMA?

TOCADA PELA PRIMEIRA VEZ? DEFESA COLETIVA, GESTÃO DE CRISES E SEGURANC̣A COOPERATIVA NO NOVO CONCEITO ESTRATÉGICO DA OTAN

CONTINUIDADES DA POLITIICA EXTERNA NORTE-AMERICANA NO PÓS-GUERRA FRIA: OS IMPERATIVOS DA DEMOCRACIA E DO MERCADO RESENHA DO LIVRO "CYBER CONFLICT: COMPETING NATIONAL PERSPECTIVES"

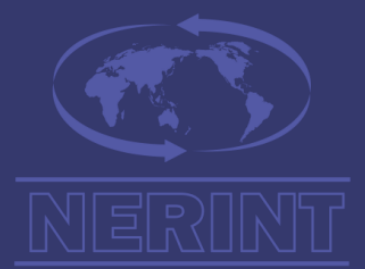




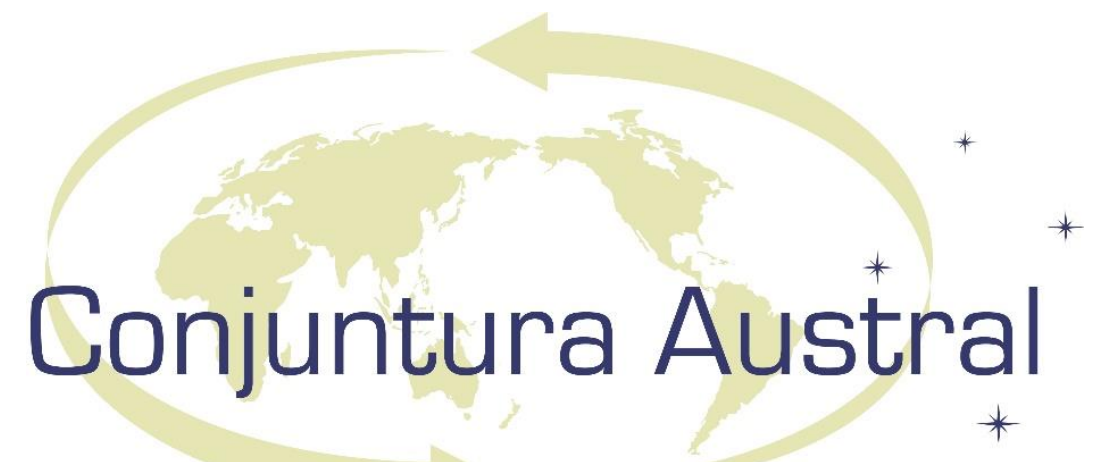




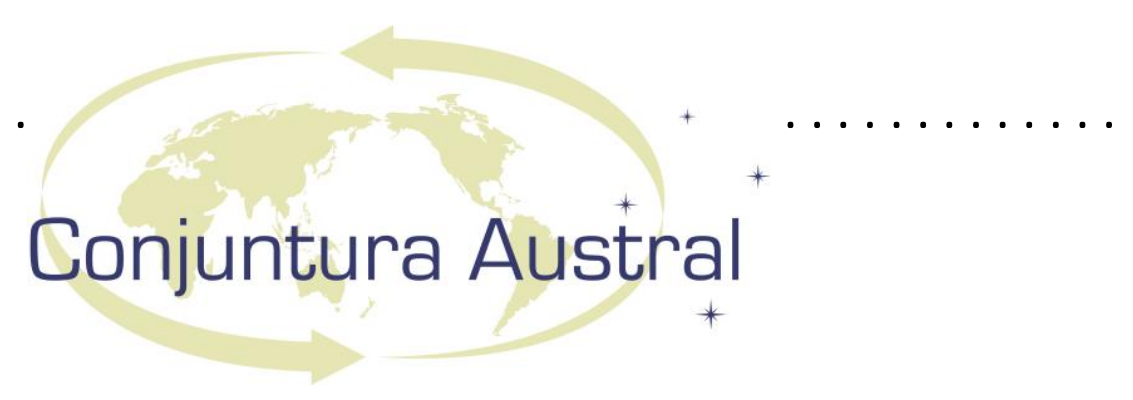

\section{FOCO E ESCOPO}

CONJUNTURA AUSTRAL é uma publicação Bimestral, em formato digital, do Núcleo de Estratégia e Relações Internacionais da UFRGS (NERINT), que publica trabalhos de relações internacionais com foco nos países que integram o Hemisfério Sul. Nesse sentido, tem como área geográfica de abrangência as relações internacionais da África, Ásia e América Latina, na perspectiva dos grandes temas da agenda de segurança, diplomacia e desenvolvimento.

A revista publica contribuições na forma de análises de conjuntura, artigos científicos e resenhas bibliográficas, cuja temática se situe na grande área de Estratégia e Relações Internacionais, com especial interesse nos temas relacionados aos países do hemisfério Sul político e suas estratégias de segurança e desenvolvimento.

\section{Missão}

Promover o debate e a reflexão sobre a conjuntura internacional, com ênfase nos processos de interesse imediato dos países em desenvolvimento.

\section{CONSELHO EDITORIAL/ Editorial Board}

Adam Habib (University of Johannesburg, África do Sul)

Amado Luiz Cervo (Universidade de Brasília, Brasil)

Antonio Jorge Ramalho (Universidade de Brasília, Brasil)

Bertrand Badie (Sciences Po, França)

Boris F. Martynov (Academia de Ciências da Rússia/ Russian Academy of Sciences)

Carlos Arturi (Universidade Federal do Rio Grande do Sul, Brasil)

Flávio Sombra Saraiva (Universidade de Brasília)

Gladys Lechini (Universidad Nacional de Rosário, Argentina)

Immanuel Wallerstein (Yale University, Estados Unidos)

Marcos Costa Lima (Universidade Federal de Pernambuco, Brasil)

Mehdi Parvizi Amineh (University of Amsterdam, Holanda)

Paulo Gilberto Fagundes Visentini (Universidade Federal do Rio Grande do Sul)

Samuel Pinheiro Guimarães (Alto Representante-Geral do Mercosul/ High General Representative of the Mercosur)

Shiguenoli Miyamoto (Universidade Estadual de Campinas, Brasil)

Willians Gonçalves (Universidade Federal Fluminense / Universidade do Estado do Rio de Janeiro, Brasil)

Sean W. Burges (Australian National Centre for Latin American Studies)

\section{COMITÊ EDITORIAL/ Editorial Committee}

André Luiz Reis da Silva (Universidade Federal do Rio Grande do Sul, Brasil) - Editor

André Moreira Cunha (Universidade Federal do Rio Grande do Sul, Brasil)

Eduardo Ernesto Filippi (Universidade Federal do Rio Grande do Sul, Brasil)

José Miguel Quedi Martins (Universidade Federal do Rio Grande do Sul, Brasil)

Luiz Augusto Estrella Faria (Universidade Federal do Rio Grande do Sul)

Marco Aurélio Chaves Cepik (Universidade Federal do Rio Grande do Sul, Brasil)

Editor Assistente / Assistant Editor

Guilherme Ziebell de Oliveira (Universidade Federal do Rio Grande do Sul

Assistente de Edição / Edition Assistant

Barbara Kebach Pfluck (Universidade Federal do Rio Grande do Sul, Brasil)

\section{CONTATO / Contact:}

Universidade Federal do Rio Grande do Sul - Faculdade de Ciências Econômicas

Programa de Pós-Graduação em Estudos Estratégicos Internacionais

Av. João Pessoa, 52 sala 33A - $3^{\circ}$ andar - CEP 90040-000 - Centro - Porto Alegre/RS - Brasil

Tel: $+55513308-3150$

Fax: +55 $513308-3963$

e-mail: conjunturaaustral@ufrgs.br.

\begin{tabular}{|l|l|l|l|l|l|}
\hline Rev. Conj. Aust. & Porto Alegre & v.6 & n.29 & p. 1-101 & Abr./Mai. 2015 \\
\hline
\end{tabular}




\section{Conjuntura Austral}

Volume. 6, Número. 29 (abr/mai.2015)

\section{ANÁLISE DE CONJUNTURA}

The Parrot, the Monkey and the Myth of Emulation or Extinction in IR p.4

Sílvia Regina Ferabolli

Arábia Saudita: Sucessão Real e Intervenção no Iêmen

Alexandre Piffero Spohr

\section{ARTIGOS}

Política Africana do Brasil: Mudança entre Lula e Dilma?

Guilherme Ziebell de Oliveira

Tocada pela Primeira Vez? Defesa Coletiva, Gestão de Crises e Segurança

Cooperativa no Novo Conceito Estratégico da OTA p.48

Diego Santos Vieira de Jesus

Continuidades da Política Externa Norte-Americana no Pós-Guerra Fria: os Imperativos da Democracia e do Mercado. p.75

Leandro Carlos Dias Conde

\section{LEITURA}

Resenha de "Cyber Conflict: Competing National Perspectives". p.97

Thiago Correa Malafaia

Normas de Submissão / Submission Standards p. 99 


\title{
Conjuntura Austral
}

\section{THE PARROT, THE MONKEY AND THE MYTH OF EMULATION OR EXTINCTION IN IR}

\section{O papagaio, o macaco e o mito do imitar ou perecer em RI}

\author{
Sílvia Regina Ferabolli ${ }^{1}$
}

On April 13, 2015, one of the most iconic figures of the Latin American left, Eduardo Galeano, passed away. Among his several, pungent works, the author of the internationally acclaimed Open Veins of Latin America (1971) left an insightful saying for IR students worth elaborating on. When asked about the future of Latin America, he said the continent had formidable challenges ahead, which could be epitomized in some very specific questions: "Will we convert ourselves in sad caricatures of the North? Will we be like them? Will we repeat the horrors of the consumer society that is devouring the planet? Will we be violent and believe that we are doomed to endless war? Or will we will generate a different world?" (Galeano, 2011). For him, the fate of the continent was dependent upon the proper addressing of these questions. By failing to do so, Latin Americans would be ere at risk of turning into nothing more than sad caricatures of ways of life imposed on them from the outside, perennially governed by systems of power that daily convince them that there is no greater virtue than acting like a parrot; that there is no greater ability than that of the monkey. The parrot and the monkey: those that mimic; the mere echoes of other people's voices.

Paying a tribute to Eduardo Galeano's life as a political activist, this brief scenario analysis/commentary will connect his ideas to a broader discussion on the emergence of the Global South and Karl Marx's reasoning that philosophers - but certainly also thinkers, scholars and intellectuals alike - should not only interpret the world, but change it. Amid the ongoing discussions on the changing character of the

\footnotetext{
${ }^{1}$ Doutora em Política e Estudos Internacionais pela School of Oriental and African Studies - SOAS, University of London. Membro do NUPEG - Núcleo de Pesquisa em Estudos Globais. Professora de Relações Internacionais da UniRitter e da Unisinos, Porto Alegre (silviaferabolli@terra.com.br).
} 


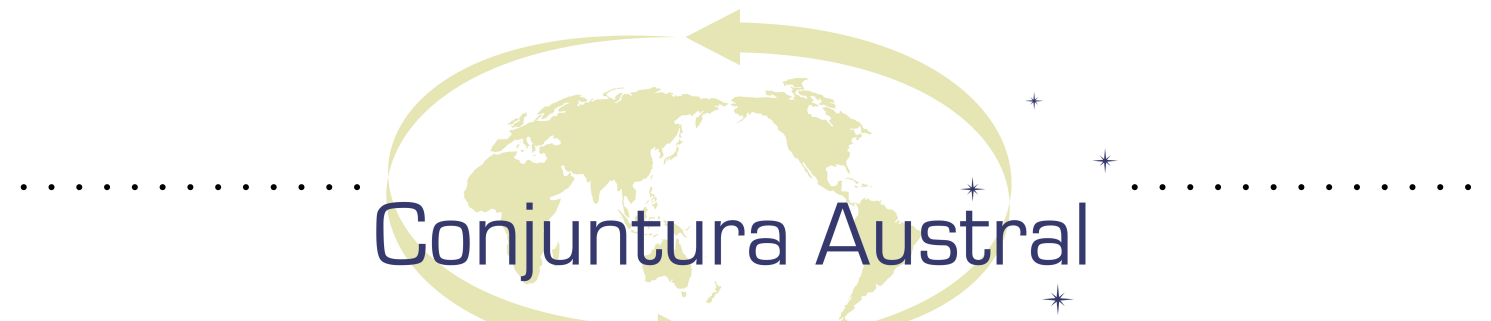

global structures of power and the rising of new players, such as the BRICS - both as an organization and collective entity and as the moniker that defines Brazil, Russia, India, China and South Africa individually -, newer, farsighted Southern thinking that can support the practice of these "heavyweights of the South" is pressing. It will therefore be argued here that alternative ways of not only theorizing but also teaching, researching and publishing in IR need to be built on the foundations of the desacralization of the academic and intellectual production of the North and the bury for good of the notion that "the West" 2 is coincident with modernity and that "the nonWest" can enter the modern world (and its post-modern moment) only to the extent that it emulates the norms established in Western Europe and the United States.

\section{Neither a parrot nor a monkey, simply an Aborigine}

When the British Empire invaded continental Australia and the islands around it, from the second half of the 18th century on, a strange phenomenon occurred: the Aborigines began to die. Thousands of them. Millions of them. Nearly extinction. One of the earliest and most comprehensive attempts to explain the mechanisms of the Aborigines' extinction was the evolutionary perspective. When seeking an explanation for the rapid depopulation of the Aboriginal areas and the projected annihilation of the indigenous inhabitants of the continent the British did recognize the role of violence: "It may be stated broadly that the advance of settlement has ... been marked by a line of blood" (McGregor 1997, 52). However, for the colonial power violence was not sufficient an explanation for the continuing disappearance of the Aborigines. "It is clear, therefore [...] that some other causes must be in operation" (McGregor 1997, 52). Prominent among these causes was the Aboriginal's inability to adjust to the European presence. It was argued that the mass death of the Aborigines was the result of

\footnotetext{
2 On the concepts of North, South, West and non-West see Ferabolli (2014): "The South" - or the periphery, the Third World or any other metageographical category that can encompass the former colonized areas of the world (as if it were even possible) [as different from - opposed to?] "the North" (or the West, the centre, the First World, or United States plus Western Europe and post-1945 Japan, or any other metageographical category that can encompass the highly industrialized and most powerful states of the system - an exercise of synthesis doomed to fail).
} 


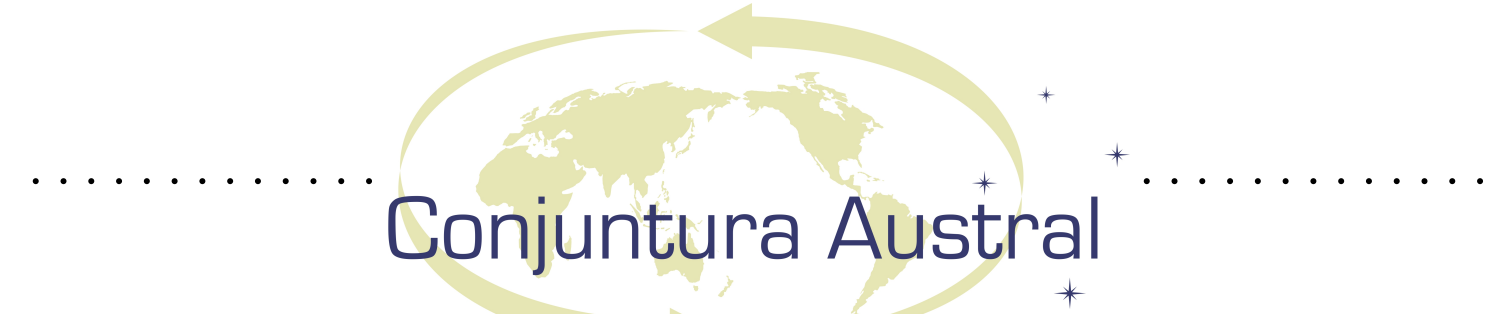

\begin{abstract}
the cumulative influence of many and various causes, all arising out of altered surrounding conditions to which either the aborigines must become adapted, or under which they must become extinct. If the aborigine could have become physically and mentally such as a white man, he would have been in equilibrium with his new surroundings. If his physical and mental nature had been able to become modified with sufficient rapidity to come into equilibrium with the changed conditions, he could have survived. But the former alternative is self-evidently an impossibility, and probably the strength of hereditary physical and mental peculiarities has made the latter also an impossibility. The consequence has been that he is rapidly and inevitably becoming extinct (in McGregor 1997, 49).
\end{abstract}

Unable to emulate the behaviour and catch up with the Europeans, the Aboriginal peoples were merely meeting their fate: extinction.

The evolutionary perspective expressed in the above account of the survival of the fittest is one of those ideas that migrate from the natural to the social world and that find in the Western-centric/Northern-centric discipline of IR the perfect space for echoing. For as a system of thought, IR sustains itself on the widespread belief that there is a centre in the world from where power irradiates to the periphery - civilizing power, enlightening power, disciplining power. Less disseminated is the fact that these forms of power are properly sustained by military, economic and political power. Therefore, those who have the coercive means impose the features defining the end point of an evolutionary timeline for the social world - and they do so by defining themselves as the highest point in the human social evolutionary chain. This Westerncentric/Northern-centric rationale is described by J.M. Blaut as the "colonizer's model of the world" an idea that rests on a "substrate of 'geographical difusionism' where progress is seen as flowing endlessly out of the centre toward the otherwise sterile periphery" (Lewis; Wigen 1997, 7).

Culturally, politically, institutionally and ideologically constrained when producing their interpretations of reality, usually referred to as "truth", Westerncentric/Northern-centric - mainstream - scholars are at the same time victims and executioners of their own entrepreneurship: the production of world-widely recognized and accepted truths about the social world. They are culturally constrained because they were raised and socialized in a world that places Western Europe and the United States ("the West" and "the North" as concept and practice) in the centre of human history; 


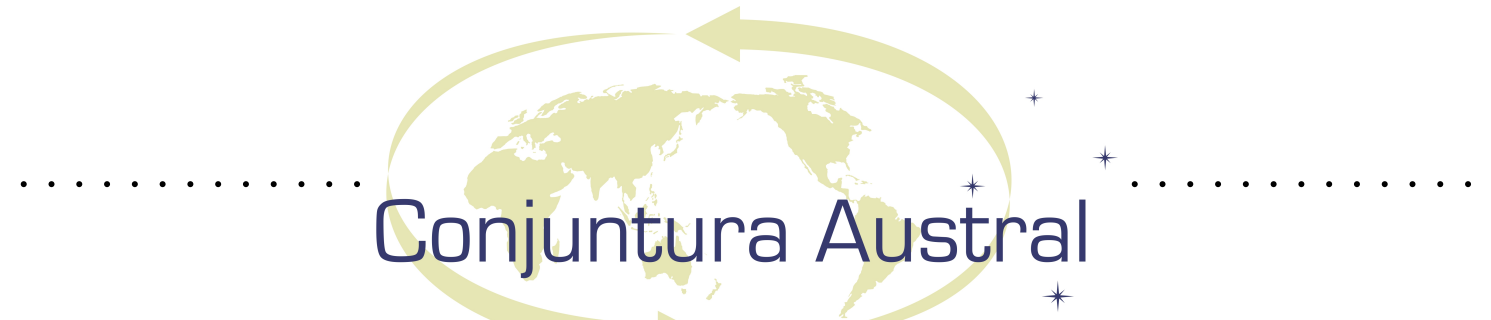

they are politically constrained because they are nationals of specific countries and as loyal citizens they defend the interests of the states where they come from - if not for loyalty, in search for governmental funding; they are institutionally constrained because they are socialized in an environment that just accepts very particular representations of the reality and to be accepted in and recognized by "the group" they have to sing the same song; finally, they are ideologically constrained because deep down in their hearts they have the feeling that they know the truth and that it is their obligation to spread all over the world the accuracy, verity and matter-of-factness of their perceptions of the reality.

Imbued with this spirit of superiority and a mixture of civilizing mission and white man's burden, Western-centric/Northern-centric mainstream scholars, from a very comfortable perspective (well-paid, well-located, well-financed), tend to create hierarchies when dealing with the international phenomena. Starting from where they are - in the West, in the North, in the centre, in the upside of the map - they look down the world and cognitively establish relationships between "the self, the "other that is like me' and the 'entirely other'", to use Levina's words (see Howitt; Suchet-Pearson 2003, 564). In this power-permeated relationship, the more the non-Western (the Southern?) follows "the norms established in Europe and northern North America" (Lewis; Wigen $1997,7)$ the less "other" they become.

It is not difficult to associate the above with the explanations for the mechanisms of Aboriginal extinction: not being able to adapt to the changes brought about by (European) civilization and incapable of absorbing the characteristics of the civilized (European) the only possible destiny was death. Indeed, civilization as equal Europeanization or Westernization/Northernization is a basic assumption of modernity as myth, as it is the fact that

\footnotetext{
Modern (European) civilization understands itself as the most developed, the superior, civilization; (...) This sense of superiority obliges it, in the form of a categorical imperative (...) to 'develop' (civilize, uplift, educate) the more primitive, barbarous, underdeveloped civilizations; The path of such development should be that followed by Europe in its own development; (...) Where the barbarian or the primitive opposes the civilizing process, the praxis of modernity must, in the last instance, have recourse to the violence
} 


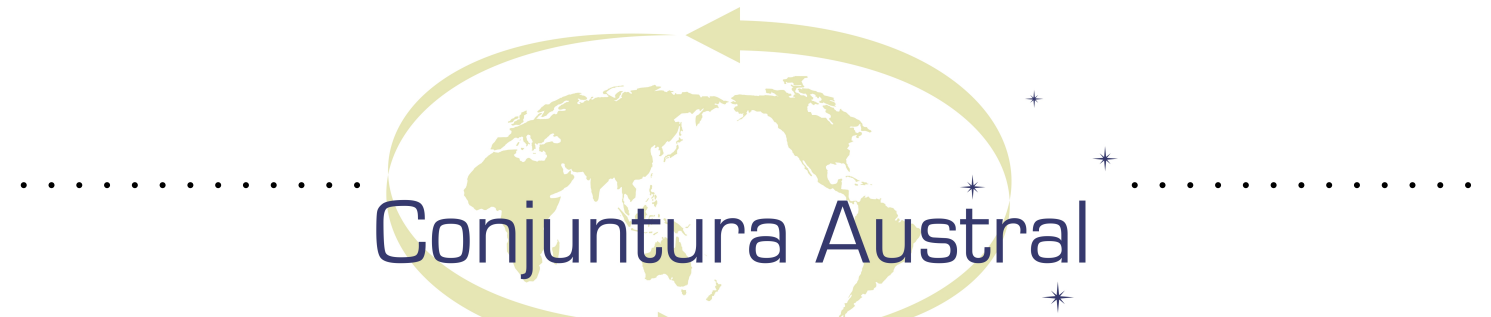

necessary to remove the obstacles to modernization; (...) From the point of view of modernity, the barbarian or primitive is in a state of guilt (for, among other things, opposing the civilizing process) (Dussel 1993, 75).

Civilization as Westernization/Northernization is not just one of the possible readings of reality, it is "a political project on a global scale: a project of homogenization through imitation and catching up" (Amin 1989, 111). Adopting the features of the supposed Western/Northern superiority expressed not only in the triad free enterprise and market, secularism and pluralist electoral democracy (Amin 1989) but also in the acceptance of the Newtonian view of the world as the only legitimate way of thinking becomes an imperative if one wants to be intelligible to mainstream scholars; failing to do it so will relegate one to complete otherness, with all the political consequences associated to it. Indeed, as D. Rose elaborates, the all-knowing Western/Northern scholar, centred in a hall of mirrors,

mistakes its reflection for the world, sees its own reflections endlessly, talks endlessly to itself, and, not surprisingly, finds continual verification of itself and its world view. This is monologue masquerading as conversation, masturbation posing as productive interaction; it is a narcissism so profound that it purports to provide a universal knowledge when in fact its violent erasures are universalizing its own singular and powerful isolation (Rose 1999, 176-177).

Edward Said speaks precisely about that when he compares the intellectual power of Orientalism with a "library" or an "archive of information commonly and, in some of its aspects, unanimously held" (1995, 41-42). He explains that this archive is bounced together by "a family of ideas and a unifying set of values proven in various ways to be effective [to explain] the behaviour of Orientals [and to supply] Orientals with a mentality, a genealogy, an atmosphere [that allows] Europeans to deal with and even see Orientals as a phenomenon possessing regular characteristics" (Said 1995, 4142). This unanimously held archive of information bounded by a unifying set of values depicted by Edward Said would keep the same powerful meaning if the word "Orientals" were replaced by "Latin Americans" or "Africans" or any of the peoples from the South. Verily, this metaphorical archive resembles the "palace of mirrors" 


\section{Conjuntura Austral}

described by Irigaray (1985), with its "solid walls of principle" that "give form [...] turn ideas into structures, edifices" producing "the absolute power of form [...] the solidity of concepts, boundaries and order" (Howitt; Pearsonn 2003, 558).

Performing simultaneous roles of agents and objects of socialization in the construction of social reality, mainstream scholars "become part of the regime of truth, imbued through and through with the imperial representations that have preceded it" (Doty 1996, 166). It is not news that Western-centric/Northern-centric scholars are embedded in the imperial representations of the Arab-Muslims, the Latin Americans, the Africans, the Indians - the non-white peoples - and that these very representations precede their reading of the world's reality. Therefore, if the concept of Global South is to have any meaningful applicability beyond the university walls the tainted Westerncentric/Northern-centric perspectives must be challenged, their epistemologies must be contested, and the echoes of their voices must be stopped.

Studies on the Global South by thinkers, scholars and intellectuals hailing from the South - geographically and ideationally speaking - is not only pressing, but vital. As I have said elsewhere (see Ferabolli 2014), Samuel Pinheiro Guimarães noted that the peripheral societies (the South) are isolated from each other and can only see each other under the vigilant eyes of the central countries (the North). The existence of this pervasive (Foucaultian panopticon) "third eye" is evident when it is observed the shortage and even the lack of studies of one peripheral state about another. Meanwhile, the sustained effort of the core countries to study the periphery and to formulate their own views about it - views that are then disseminated and absorbed by the very periphery (Guimarães 1999, 17 my italics) - is noteworthy. As insurmountable a task as it may sound, changing the global architecture of power will require more than altering the overall military, economic, and political capacity of the South vis-à-vis the heavyweights of the North; it will rather demand that the virtues of the monkey and the parrot be replaced with those of the critical, enlightened homo sapiens. 


\section{Conjuntura Austral}

\section{REFERENCES:}

AMIN, Samir . Eurocentrism. Monthly Review Press, 1989.

BREEN, Shayne. 'Extermination, Extinction, Genocide: British Colonialism and Tasmanian Aborigines', in LEMARCHAND, R. Forgotten Genocides: Oblivion, Denial and Memory. Philadelphia, PA: University of Pennsylvania Press, pp. Pages 7190, 2011.

DOTY, R. L. Imperial Encounters: The Politics of Representation in North-South Relations. Minneapolis: University of Minnesota Press, 1996.

DUSSEL, E. 'Eurocentrism and Modernity: Introduction to the Frankfurt Lectures'. Boundary 2, v. 20, n. 3. The postmodernism debate in Latin America, pp. 65-76, 1993.

FERABOLLI, Silvia. Arab Regionalism. A Post-Structural Perspective. Routledge Studies in Middle Eastern Politics. New York; London: Routledge,2014.

GALEANO, Eduardo (2011). Interview to Silvio Tendler, in $\boldsymbol{O}$ mundo global visto do lado de cá, available at $<$ https://www.youtube.com/watch? $\mathrm{v}=-\mathrm{UUB}$ 5DW mnM $>$.

GUIMARAES, Samuel P. Quinhentos anos de periferia. Porto Alegre/Rio de Janeiro: Editora da UFRGS/Contraponto, 2001.

HOWIT, R. and SUCHET-PEARSON, S. Ontological pluralism in contested cultural landscapes, in ANDERSON K., DOMOSH M., PILE S. and THRIFT N. (eds) Handbook of Cultural Geography. London, Sage Publications: 557-569, 2003.

IRIGARAY, Luce. This sex which is not one. Trans. Catherine Porter. Ithaca: Cornell University Press, 1985.

LEWIS, Martin W.; WIGEN, Karen E.. The Myth of Continents: A Critique of Metageography. CA: University of California Press,1997.

MCGREGOR, Russel. Imagined Destinies: Aboriginal Australians and the Doomed Race Theory, 1880-1939. Melbourne: Melbourne University Press., 1997.

ROSE, D. B. Indigenous Ecologies and an Ethic of Connection, in LOW, N. (Ed.), Global Ethics and Environment, Routledge, London, pp. 175-187, 1999.

SAID, Edward. Culture and imperialism. London: Vintage, 1995. 


\section{Conjuntura Austral}

SOUZA, Claudio C.D.; FERABOLLI, Silvia. O retorno dos idiotas. Biblioteca Diplo (Le Monde Diplomatique Brasil), available at $<$ http://diplo.org.br/2007-12,a2070>, 2007.

Recebido em 04 de maio de 2015. Aprovado em 12 de maio de 2015. 


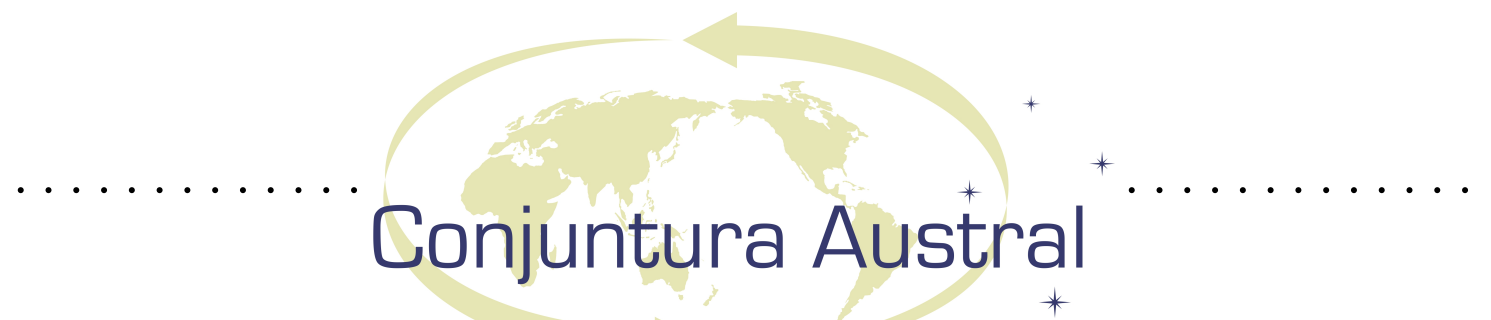

\begin{abstract}
This brief scenario analysis will argue that alternative ways of not only theorizing but also teaching, researching and publishing in IR (International Relations) need to be built on the foundations of the desacralization of the academic and intellectual production of the North and the bury for good of the notion that "the West" is coincident with modernity and that "the non-West" can enter the modern world (and its post-modern moment) only to the extent that it emulates the norms established in Western Europe and the United States.
\end{abstract}

Keywords: Eduardo Galeano; Global South; North-South divide;

\title{
RESUMO
}

Esta breve análise de conjuntura irá argumentar que formas alternativas de teorizar, ensinar, pesquisar e publicar em RI (Relações Internacionais) precisam ser construídas sobre os alicerces da dessacralização da produção acadêmica e intelectual do Norte e do sepultamento definitivo da noção de que apenas "o Ocidente" é coincidente com a modernidade e de que "o não-ocidental" somente pode entrar no mundo moderno (e em seu momento pós- moderno) na medida em que ele emula as normas estabelecidas na Europa Ocidental e nos Estados Unidos

Palavras Chave: Eduardo Galeano; Sul Global; divisão Norte-Sul 


\title{
Conjuntura Austral
}

\section{ARÁBIA SAUDITA: SUCESSÃO REAL E INTERVENÇÃO NO IÊMEN}

\section{Saudi Arabia: Royal Succession and Intervention in}

Yemen.

\author{
Alexandre Piffero Spohr ${ }^{1}$
}

\section{O sistema político saudita e o processo sucessório}

O Reino da Arábia Saudita, originado pela aliança entre Muhammad bin Saud, criador da Casa dos Saud, e Muhammad Abd bin al-Wahhab, fundador do movimento wahabita, no século XVIII, enfrentou sua sexta sucessão monárquica em janeiro de 2015. Tendo sido criado oficialmente em 1932 pelo patriarca da família, Abd al-Aziz ibn Saud, neto do criador da casa, o reino foi fruto de uma estratégia de reconstrução da monarquia a partir da expansão pela Península Arábica. Ao período de conquista territorial sucedeu uma grave crise econômica, causada pela falta de recursos na desértica região ocupada, revertida a partir da descoberta de petróleo e da aliança com os Estados Unidos durante a Segunda Guerra Mundial (LONG; MAISEL, 2010).

A rudimentar organização política saudita progrediu de forma gradual, valendose das estruturas políticas presentes em territórios ocupados, especialmente do Hijaz, região em que se localizam as duas cidades sagradas de Meca e Medina. A primeira sucessão monárquica se deu em 1953 pelo filho mais velho, Saud. A falta de aptidão de Saud para governar conforme o esperado pela família real e pela liderança religiosa e sua fraca saúde levaram à sua abdicação em favor de seu meio-irmão Faisal em 1964 (HERB, 1999). Assim, consolidou-se o modelo sucessório que seria seguido: os próximos monarcas sauditas seriam os filhos mais velhos do primeiro rei, escolhidos com o consentimento dos demais membros da família, garantindo a manutenção de posições e políticas domésticas e internacionais.

\footnotetext{
${ }^{1}$ Graduado em Relações Internacionais e mestrando em Ciência Política na Universidade Federal do Rio Grande do Sul (UFRGS) (alexandre.spohr@gmail.com).
} 


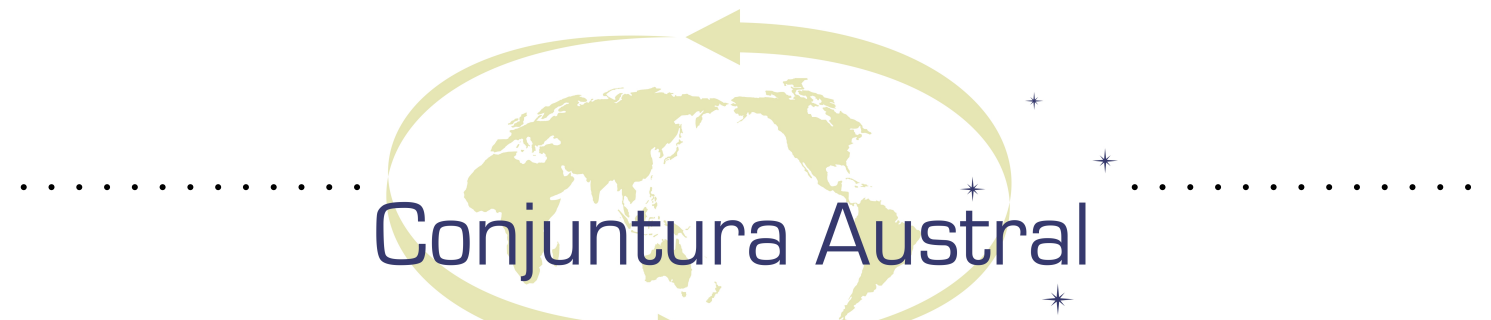

Segundo Long e Maisel (2010, p. 41, tradução nossa), "se o rei Abd al-Aziz foi o criador do Estado saudita moderno, o rei Faisal foi o arquiteto do reino petrolífero moderno",2, estabelecendo mais elementos a serem continuados por seus sucessores. Até o atual momento sucessório, mais três monarcas governaram a Arábia Saudita: Khalid (1975-1982), Fahd (1982-2005) e Abdullah (2005-2015). Durante o reinado de Fahd, a Lei Saudita Básica de Governança em 1992, principal documento legal de organização da monarquia, modernizou o país sem afetar as estruturas de poder nem ameaçar a estabilidade política, tendo criado o Majlis saudita. Embora tenha um nome e uma composição semelhante à de um parlamento, esse não possui as funções legislativas esperadas de um, mas apenas a função de um órgão consultivo do monarca. Abdullah, que governou efetivamente desde 1996, promoveu a criação do Conselho de Lealdade em 2006 para determinar a linha sucessória ao trono saudita (IHS JANE’S, 2009a).

A Arábia Saudita não possui constituição, seguindo a xaria e tendo legislação complementar sobre temas não presentes nela. Seu documento legal que assume certas funções de uma constituição é a Lei Básica de Governança, que oficializou seu sistema político. Nenhum dos principais órgãos políticos sauditas é escolhido pela população, sendo todos definidos pelo rei ou pela família real. Os principais postos e as principais organizações públicas no país são chefiados por integrantes da família Saud. Alguns filhos de Abd al-Aziz já abdicaram de seu direito ao trono por considerarem seus meiosirmãos mais capazes de governar o país (KECHICHIAN, 2001, BRADLEY, 2005).

O processo decisório está extremamente concentrado no monarca e em indivíduos de sua confiança; é sua a responsabilidade pela seleção dos chefes dos principais órgãos que o auxiliam a promover seu plano de governo. A Lei Básica de Governança afirma que o Estado saudita possui três autoridades: executiva, judicial e regulatória, sendo todas referenciadas pelo monarca, que é também o comandante das forças armadas (SAUDI ARABIA, 1993). A escolha do rei saudita deve obedecer à estipulação feita pelo rei fundador, Abd al-Aziz, de que os reis do país deveriam ser seus descendentes, em um primeiro momento seus filhos e, depois, seus netos.

\footnotetext{
${ }^{2}$ Do original em inglês.
} 


\section{Conjuntura Austral}

Até 2006, o segundo príncipe na linha sucessória era escolhido pelo rei no momento em que esse tomava posse, substituindo o herdeiro quando da morte do rei. $\mathrm{O}$ Conselho de Lealdade se tornou responsável pela escolha do novo príncipe herdeiro, quando do falecimento do monarca. Os membros do Conselho de Lealdade são filhos e netos de Abd al-Aziz, podendo julgar que o atual rei não está mais apto a governar por motivos de saúde e retirá-lo do cargo em prol do príncipe herdeiro (SAUDI ARABIA, 2006). Essa instituição surgiu com o propósito de resolver um potencial conflito quando da transmissão do trono para a nova geração.

\section{A ascensão do rei Salman}

Seguindo o modelo de seus meios-irmãos e antecessores, Salman ascendeu ao trono em janeiro de 2015 após a morte de Abdullah. O rei Abdullah ficou conhecido por seu perfil reformista para os padrões sauditas, tendo dado diversas demonstrações e tomadas algumas ações em prol da redução do conservadorismo das práticas sociais positivadas nos decretos do país. A partir do afastamento de clérigos conservadores, sem comprometer o importante papel desempenhado pelos religiosos na manutenção da estabilidade social do país, ele sinalizou para o aumento da participação feminina na política (STEPHENS, 2015a). Contudo, a situação das mulheres e a participação política dos cidadãos no país se mantiveram extremamente restringidas pela legislação saudita (WHILE, 2015).

Salman faz parte de um grupo dentro da família Saud conhecido como Sudairi Seven. Esse grupo consiste de sete filhos de uma das esposas de Abd al-Aziz que se articularam para defender suas posições dentro das divergências políticas da família (LONG; MAISEL, 2010). O primeiro desses irmãos foi o rei Fahd; seus dois irmãos Sultan e Nayef foram príncipes-herdeiros de Abdullah, mas faleceram antes de poderem ascender ao trono. Os outros três príncipes que integram o grupo foram removidos da linha sucessória por decisão familiar. O reinado de Abdullah foi marcado por especulações sobre as tensões existentes entre ele e os Sudairi Seven, especialmente no que concerne a predominância desses na linha sucessória (KHATID, 2015). Pouco 


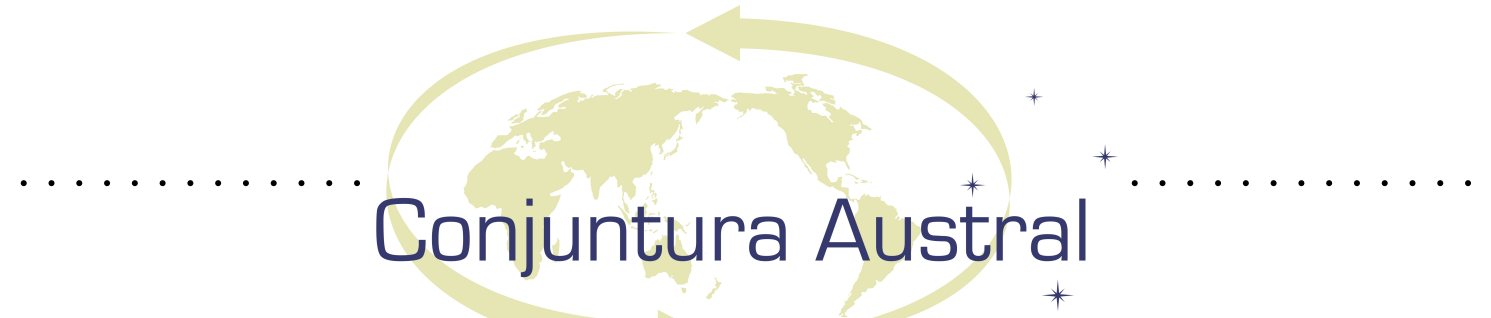

dessas disputas veio à tona para a população saudita, sendo elas definidas reservadamente em reuniões familiares (BUTT, 2015).

O rei Salman acumulou poder de decisão durante o ano de 2014 devido à deterioração do estado de saúde de seu meio-irmão, que alcançara os 90 anos (WHO, 2015). Assim, há uma comunhão de interpretações de que a transição política não afetará as políticas e os rumos traçados para o reino (HUBBARD, 2015b, KECHICHIAN, 2015). Contudo, o novo rei já tomou medidas para assentar sua posição, retirando dois filhos de Abdullah que ocupavam postos importantes da política saudita e colocando seu filho Mohamed como ministro da defesa (SAUDI, 2015b; SALMAN, 2015). Ainda, aponta-se que a saúde do novo monarca possa ser uma ameaça a seu reinado, que pode ter uma duração mais curta do que o esperado, sendo o último dos irmãos do Sudairi Seven a assumir o posto (SULLIVAN; SLY, 2015). O WikiLeaks apresentou falas do rei Salman contrário à introdução de democracia no país, e entende-se que seu foco será a criação de empregos e de infraestrutura para evitar que a queda do preço do petróleo afete a estabilidade social e a confiança empresarial (SALMAN, 2015, NEW, 2015).

A sucessão monárquica deste ano ainda apresentou dois avanços importantes para a dominação política da família Saud: a escolha do último príncipe herdeiro entre os filhos de Abd al-Aziz e do primeiro na linha sucessória entre os netos. A escolha de Muqrin, o mais novo dos filhos de Abd al-Aziz, aos 69 anos, para príncipe herdeiro não significou maiores alterações para a política saudita, uma vez que suas posições são tidas como comuns às dos demais meios-irmãos (SULLIVAN; SLY, 2015).

Enquanto isso, a escolha do primeiro sucessor entre os netos marcou o início da solução de um dos impasses apresentados para a política saudita por analistas como Kechichian (2001), Herb (1999) e Long e Maisel (2010): a passagem do poder entre as gerações da família Saud. Mohamed ibn Nayef, filho de um dos integrantes do Sudairi Seven, antigo príncipe-herdeiro Nayef, é apresentado como vencedor de uma suposta disputa com o primo Miteb, filho de Abdullah. Mantido no posto de ministro da Guarda Nacional, Miteb é tido como menos popular do que seu primo Mohamed, ministro do interior (NAAR, 2015, KHATID, 2015). Mohamed é formado no Ocidente, nos Estados 


\section{Conjuntura Austral}

Unidos, diferente do pai e dos tios, embora não apresente posições muito distintas dos demais parentes, representando, assim, uma possível renovação sem promessas de maiores mudanças (HUBBARD; KRIKPATRICK, 2015).

Em abril de 2015, uma nova alteração na linha sucessória foi posta em prática pelo novo rei. O príncipe herdeiro Muqrin foi retirado da linha sucessória em favor de seu sobrinho, Mohamed ibn Nayef, e o filho do atual rei, Mohamed ibn Salman, foi escolhido para suceder seu primo (HUBBARD, 2015a). Assim, foi antecedida a passagem do poder para a nova geração, com os dois próximos herdeiros sendo netos do fundador da monarquia saudita. Além disso, o poder do grupo do Sudairi Seven é reforçado, uma vez que ocupa o posto máximo do país e as duas posições sucessórias.

\section{Política externa e regional saudita}

O Reino da Arábia Saudita possui duas tendências opostas em sua inserção internacional: um isolamento do resto do mundo e uma forte dependência do sistema internacional. Por um lado, o reino saudita busca se manter isolado de influências externas que possam ameaçar seu regime, seja por deslegitimá-lo, seja por representar uma ameaça física à sua integridade territorial. Por outro lado, sua própria organização econômica depende do sistema internacional, uma vez que suas duas principais atividades envolvem um elevado grau de integração, física e infraestrutural, com o resto do mundo: a exportação de petróleo e a peregrinação de muçulmanos durante o Hajj, para as cidades sagradas de Meca e Medina (JOFFE, [2010]).

A Arábia Saudita foi o único país árabe que não foi controlado por potências europeias. O receio para com as potências imperialistas europeias que dominavam os povos ao redor da Arábia Saudita e a necessidade de manter suas defesas fortes para garantir o território conquistado levaram os sauditas a se manterem isolados e terem receio no estabelecimento de relações com outros países, especialmente europeus. Long e Maisel (2010) atribuem parte dessa tendência de isolamento da Arábia Saudita a características intrínsecas ao povo saudita ${ }^{3}$, gerando um militarismo em um ambiente

\footnotetext{
${ }^{3}$ Essa tendência seria fruto da mistura de um sentimento de autoconfiança cultural (identidade árabe em linhas genealógicas que remetem à época de Maomé e à sua herança islâmica) e da "síndrome de cerco"
} 


\section{Conjuntura Austral}

que se acredita ser conflituoso e hostil. As forças armadas sauditas, além de se voltarem a proteger as fronteiras do reino, têm vital função na proteção das reservas de petróleo do país, dependendo de apoio externo, especialmente estadunidense.

Devido a suas reservas de petróleo e a sua grande produção, a Arábia Saudita passou a desempenhar um papel vital na organização do mercado energético mundial. Tal posição foi conquistada a partir da criação da Organização dos Países Exportadores de Petróleo em 1960 e da completa dominação pelos sauditas da ARAMCO Saudita, a maior empresa de petróleo do mundo em termos de produção segundo a Forbes (THE, 2012). Com a OPEP, os países produtores passaram a exigir maior controle sobre o mercado de petróleo. Dominando a ARAMCO, os sauditas puderam controlar os rumos do seu principal bem de exportação interna e externamente. Alhajji e Huettner (2000) afirmam que a Arábia Saudita é o único país da OPEP que conseguiu variar sua produção voluntariamente, se mostrando, assim, dominante no mercado de petróleo e na condução global desse mercado.

As relações da Arábia Saudita com a maior parte dos atores internacionais sofreram alterações principalmente por causas externas ao reino. A aproximação com os Estados Unidos só sofreu oscilações por conta da política estadunidense para o Oriente Médio e dos atentados de 11 de setembro de 2001. Apenas um dos monarcas sauditas, Saud, optou por uma política menos cooperativa quando do início de seu reinado, tendo sido o único rei saudita afastado do trono (GAUSE III, [2010]).

A ascensão do rei Salman ao trono saudita não deve provocar maiores mudanças na política energética e nas relações do país com os Estados Unidos. Contudo, os últimos anos do reinado de Abdullah testemunharam o surgimento de tensões entre os dois aliados. Essas foram causadas por discordâncias sobre a solução das crises na Síria e no Iraque e, segundo alguns analistas, sobre a política energética saudita, que vem inviabilizando diversos projetos energéticos ao redor do mundo, como o gás de xisto nos Estados Unidos (REED; KRAUSS, 2015, COOPER; NORDLAND; MacFARQUHAR, 2015). A preocupação estadunidense, e ocidental, de manter boas 


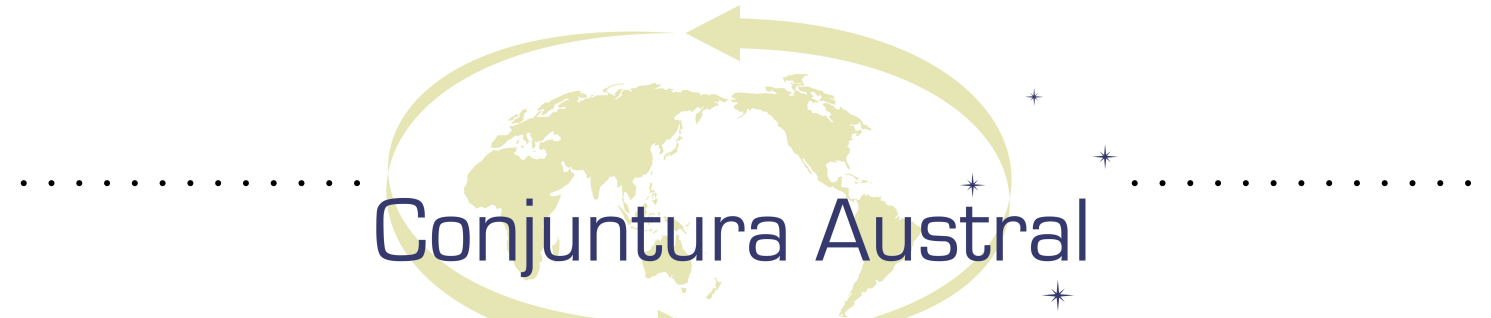

relações com Riad pode ser vista pelo grande número de chefes de Estado e de governo ocidentais presentes na cerimônia de posse do novo rei (SAUDI, 2015a). Tal preocupação ensejou críticas de alguns veículos de comunicação, se voltando contra as congratulações ao antigo monarca por suas posições acertadas, uma vez que o extremamente fechado regime saudita apresenta violações aos direitos humanos e práticas notórias de desrespeito aos direitos das mulheres (WHILE, 2015).

Além de ser instrumento para influenciar o mercado petrolífero mundial, o petróleo permite à Arábia Saudita conduzir sua política regional, utilizando suas rendas em investimentos e projetos de assistência predominantemente voltados a seus vizinhos árabes. Tais fluxos financeiros se voltam para manter a estabilidade da região e para permitir uma maior influência sobre os vizinhos. Também foram utilizados para apoiar aliados dos sauditas em conflitos na região, como os iemenitas do norte contra os do sul (1962-70), os iraquianos contra os iranianos (1980-8), a mujahidin afegã contra o governo central afegão e os soviéticos (1979-89) (LONG; MAISEL, 2010).

O conservadorismo da política interna saudita se reflete em sua política externa, priorizando a manutenção da estabilidade regional e se refletindo na escolha de seus aliados nos conflitos da região. Desafios à manutenção da estabilidade, como o nasserismo nas décadas de 1950 e 1960 e a Revolução Iraniana em 1979, são combatidos por Riad (FERABOLLI, 2009, HALLIDAY, 2005). Outro componente importante da política externa saudita é o mundo islâmico: sua promoção enquanto defensora da causa islâmica e a busca pelo fortalecimento do islamismo, e em certa medida do wahabismo.

A principal área de influência da política externa saudita é o grupo de monarquias que compõe o Conselho de Cooperação do Golfo: Bahrein, Catar, Emirados Árabes Unidos, Kuwait, e Omã. A cooperação entre esses países no campo econômico, promovendo a integração econômica, a comunhão de posições para a região e a preponderância saudita sobre os demais membros tornam o grupo um especial componente da inserção internacional do reino. Apesar da cooperação entre os demais países do bloco e a Arábia Saudita, alguns pontos de tensão se criaram, tendo em vista que as demais monarquias buscam fugir de uma posição de subserviência aos sauditas, 


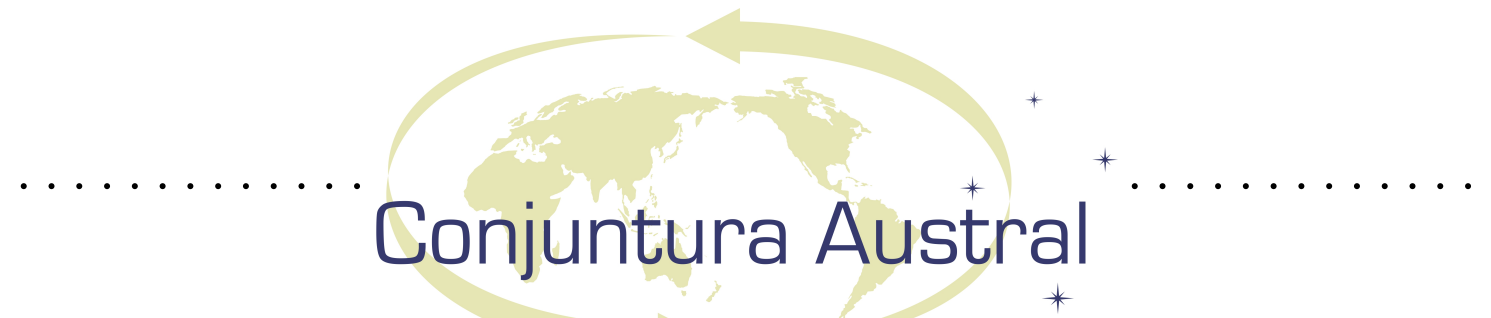

com acordos bilaterais de apoio militar ou de livre comércio com os Estados Unidos. Disputas territoriais, que marcaram o início da interação de Riad com seus vizinhos, foram aos poucos resolvidas através de negociação, mas novas disputas vêm emergindo com a descoberta de novas reservas de petróleo, também com outros atores regionais, especialmente o Irã (LONG; MAISEL, 2010, IHS JANE’S, 2009a).

Após um início conturbado devido à expulsão da família monárquica dos tronos de Amã e Bagdá ${ }^{4}$, as relações da Arábia Saudita com Jordânia e Iraque andaram em direções opostas. A gradual melhora nas relações Riad-Amã foi contrastada pelo aumento das tensões entre Riad e Bagdá após a instauração de uma monarquia. Atualmente, a crise iraquiana e a presença do Estado Islâmico se apresentam como ameaças à estabilidade regional para os sauditas, ainda que sua atuação prática para resolver a situação seja reduzida.

O Irã se apresenta como grande rival saudita desde sua revolução islâmica, tornando a Síria, o Hezbollah no Líbano e o Hamas na Palestina elementos de preocupação para a diplomacia saudita. Ainda, Riad busca desempenhar um importante papel na resolução da questão palestina, tendo oferecido mediação em diversos momentos (IHS JANE'S, 2009a, LONG; MAISEL, 2010). Salman, e seus sucessores, sinalizam para a manutenção das linhas gerais da política regional saudita, ainda que alguns pontos de indefinição do reinado anterior frente às atuais crises no Oriente Médio persistam abertos a novas ações estratégicas sauditas (KECHICHIAN, 2015, STEPHENS, 2015a). A consolidação de um ramo da família na cúpula política saudita reforça os sinais recentes de mudança de tom na política regional, com um perfil mais ativo da diplomacia, como a questão do Iêmen atesta.

\section{A questão do Iêmen na política externa saudita}

A história do Iêmen foi marcada por tensões, conflitos e instabilidade, devido à ocupação estrangeira do território que hoje integra o país. Seu norte foi parte do Império Otomano, conquistou sua independência sob uma monarquia e se tornou república em

\footnotetext{
${ }^{4}$ Os hashemitas controlavam a atual região do Hijaz saudita, tendo sido os guardiões das cidades sagradas antes dos monarcas sauditas.
} 


\section{Conjuntura Austral}

1962 após uma guerra civil em que os dois projetos pan-arabistas, nasserista e saudita, se confrontaram, com o Cairo apoiando a república, e Riad, a monarquia. Seu sul foi colônia britânica até 1967, quando se tornou república popular, de orientação marxista. As divergências entre os dois Estados geraram tensões e conflitos fronteiriços. Apesar da unificação iemenita em 1990 com o presidente do norte, Ali Abdullah Saleh, e o primeiro-ministro do sul, Haidar Abu Bakr al-Attlas, o país manteve diversas tensões internas, incentivadas por seus vizinhos e potências extrarregionais (IHS JANE'S, 2009b).

Após tentativas de secessão de parte do sul, crescimento de grupos rebeldes houthis, grupo xiita zaidita que desafia o governo militarmente desde 2004, e o recrudescimento do grupo al-Qaeda na Península Arábica (AQAP, sigla em inglês) (IHS JANE'S, 2009b), o governo iemenita sofreu forte desestabilização em 2011 durante o movimento que ficou conhecido como Primavera Árabe. O presidente Saleh, que governava desde a unificação, não obteve sucesso na repressão da oposição, e o conflito armado tomou diversas partes do país, resultando em sua renúncia em 2012 (YEMEN'S, 2012). Seu sucessor, Abd Rabbuh Mansur Hadi, nascido na província de Aden, na região sul do país, governou em meio ao aumento das tensões desestabilizadoras até fevereiro de 2015, quando se retirou para a província de Aden, de onde vem governando com apoio de diversos países da região e de potências ocidentais. A capital do país, Sana, foi tomada pelos rebeldes houthis em setembro de 2014, aumentando seu poder sobre o governo gradualmente. Inicialmente obtiveram a renúncia do primeiro-ministro e, após meses de impasse sobre a escolha de um novo, receberam a renúncia de Hadi, rejeitada pelo parlamento iemenita (REARDON, 2015b).

As tentativas de mediação entre o governo de Hadi e os houthis, tradicionais governantes do Iêmen, pelas Nações Unidas e pelos Estados do Golfo falharam (COOPER; NORDLAND; MacFARQUHAR, 2015). Atualmente, os houthis se organizam desde Sana sob o comando de Mohammed Ali al-Houthi, presidente do comitê revolucionário iemenita, e tentam se expandir sobre o resto do território do país, enquanto outros grupos rebeldes ganham poder, como a AQAP e o Estado Islâmico. O ex-presidente Saleh, também houthi, ainda que tenha combatido os grupos rebeldes 


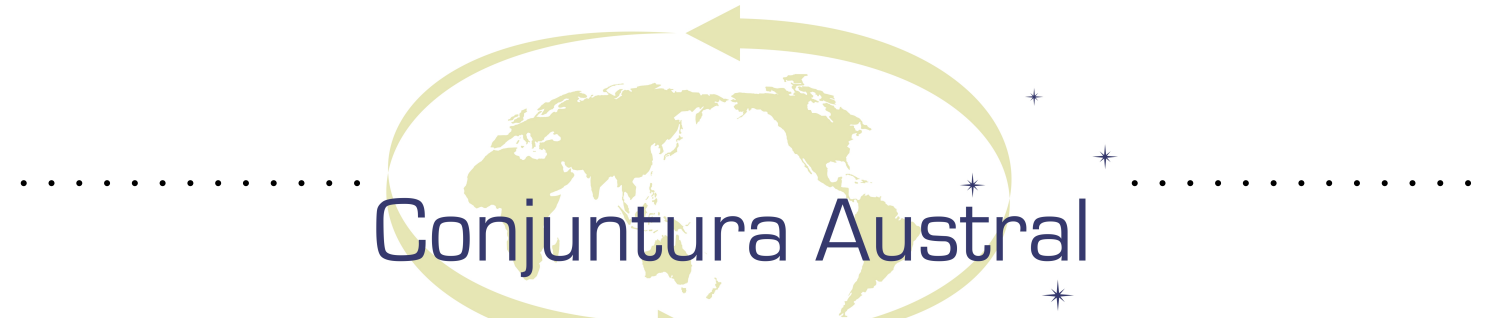

durante sua presidência, apoia a tomada de poder, e grupos leais a ele vêm auxiliando na ocupação de outras partes do país, podendo levá-lo de volta a uma posição de liderança na política iemenita (REARDON, 2015b).

Alguns analistas, especialmente os defensores de ações enérgicas pelas monarquias do Golfo contra a insurgência houthi, apontam para a ação desse grupo xiita como proxy do governo iraniano. Contudo, tal interpretação, apesar de poder ser baseada em uma relação entre Teerã e os houthis, corrobora visões sectárias dos conflitos do Oriente Médio. A disputa entre grupos com diferentes bases de sustentação não pode ser simplificada pela atribuição de um caráter de proxy a seus pleitos, uma vez que a própria eleição de Hadi, candidato único, não é tão incontestável como pode ser apresentada (MARANDI, 2015).

A Arábia Saudita dedica historicamente especial atenção para seu vizinho Iêmen, devido ao seu temor com relação às instabilidades no populoso país ao sul, intervindo em seus assuntos domésticos antes e depois da unificação iemenita para evitar que as tensões de lá repercutissem em seu território. Após o fim do conflito e da unificação iemenita em 1991, tensões fronteiriças permaneceram entre Sana e Riad, sendo apenas resolvidas em 2000. Com a assinatura de um acordo fronteiriço, os dois países passaram a desenvolver uma maior cooperação, vencendo obstáculos prévios. Importantes elementos da cooperação saudita-iemenita são o antiterrorismo, o combate ao tráfico de armas e drogas, e outras questões securitárias. Os monarcas sauditas retiraram, inclusive, suas objeções à entrada do Iêmen para o CCG (IHS JANE'S, 2009a). A aproximação com o Iêmen sobreviveu à queda de Saleh, tendo inclusive se intensificado.

A eclosão da atual crise iemenita, em meio à sucessão monárquica saudita, trouxe à tona uma política assertiva por parte do novo monarca, que optou por atuar ativamente para debelar um dos focos de instabilidade regional, ao contrário de suas posições para com a Síria e o Estado Islâmico. Nesses, sua posição assertiva e definitiva não é acompanhada por ações práticas, que propiciem soluções de sua conveniência. A preocupação com o conflito no próximo e populoso vizinho, além do fato de a Arábia Saudita ser o principal Estado afetado pela crise na região que não o próprio Iêmen, 


\section{Conjuntura Austral}

ensejou a criação de uma coalizão, sob a liderança saudita, para lidar com a situação. A partir da Operação Tempestade Decisiva, Riad busca neutralizar atores não estatais e combater conflitos sectários, tendo cortado a ajuda ao governo iemenita e se oposto ao tom de conciliação com os houthis que os Estados Unidos pareciam propor (ALBOGAMI, 2015, COOPER; NORDLAND; MacFARQUHAR, 2015).

A operação é composta por Arábia Saudita, Emirados Árabes Unidos, Kuwait, Bahrein, Catar, Marrocos, Egito, Sudão, Jordânia e Paquistão, que declararam buscar auxiliar Hadi a acabar com a ameaça houthi. A liderança saudita demonstra o interesse do país em resolver a crise de seu vizinho historicamente mais instável. Além disso, sua percepção do conflito como parte de sua rivalidade com o Irã aumenta a necessidade de assertividade na condução da questão (AL-BATATI; GALDSTON, 2015). O rei Salman parece ter levado tal ponto em extrema consideração, sendo a coalizão apontada por alguns autores como parte de uma estratégia de aumentar as desconfianças internacionais para com Teerã em meio às negociações sobre seu programa nuclear na Suíça (MARANDI, 2015, STEPHENS, 2015b).

A tática até então adotada, de bombardeio de alvos supostamente houthis no norte do Iêmen, vem causando intensa destruição de infraestrutura em um país cuja pobreza é apontada como uma das principais causas do conflito, por gerar intensa disputa por recursos. A opção de invasão terrestre possui um histórico de insucesso para os sauditas, mas parece ignorar-se a baixa adesão popular à campanha houthi, o que poderia ser utilizado para uma saída menos sangrenta para o conflito (STEPHENS, 2015b, MARANDI, 2015). O resultado da assertividade do novo rei saudita na política regional até então parece ser o avanço na deterioração da situação e das capacidades iemenitas, ainda que com apoio do presidente eleito, o que contribui para o recrudescimento de grupos rebeldes, como al-Qaeda e Estado Islâmico (GASIM, 2015), se assemelhando aos resultados das intervenções no Iraque, na Líbia e na Síria. 


\section{Conjuntura Austral}

\section{REFERÊNCIAS:}

AL-BATATI, S.; GALDSTON, R. Dozens Are Reported Killed as Saudi-Led Strike Hits Camp for Displaced Yemeni Civilians. The New York Times. Nova Iorque, 30 mar. 2015. Disponível em:

$<$ http://www.nytimes.com/2015/03/31/world/middleeast/yemen-camp-airraid.html?_r=0>. Acesso em: 6 abr. 2015.

AL-BOGAMI, M. Why Saudi Arabia and Israel oppose Iran nuclear deal. Al Jazeera. Doha, 3 abr. 2015. Disponível em:

$<$ http://www.aljazeera.com/news/2015/04/saudi-arabia-israel-oppose-irannuclear-deal-150401061906177.html>. Acesso em: 6 abr. 2015.

ALHAJJI, A. F.; HUETTNER, D. OPEC and World Crude Oil Markets from 1973 to 1994: Cartel, Oligopoly, or Competitive? The Energy Journal. n. 3. p. 31-60. 2000.

BRADLEY, J. R. Saudi Arabia Exposed: Inside a Kingdom in Crisis. Nova Iorque: Palgrave Macmillan, 2005.

BUTT, G. Saudi Arabia: Why succession could become a princely tussle. BBC. Londres, 23 jan. 2015. Disponível em: <http://www.bbc.com/news/world-middleeast-29792691>. Acesso em: 6 abr. 2015.

COOPER, H.; NORDLAND, R.; MacFARQUHAR, N. New Saudi King and U.S. Face Crucial Point in the Relationship. The New York Times. Nova Iorque, 23 jan. 2015. Disponível em:

$<$ http://www.nytimes.com/2015/01/24/world/middleeast/for-king-salman-newsaudi-ruler-a-region-in-upheaval.html>. Acesso em: 6 abr. 2015.

FERABOLLI, S. Relações Internacionais do Mundo Árabe: Os Desafios para a Realização da Utopia Pan-Arabista. Curitiba: Juruá, 2009.

GAUSE III, F. G. Saudi-American Relations. In: MIDDLE EAST INSTITUTE. The Kingdom of Saudi Arabia, 1979-2009: Evolution of a Pivotal State. Washington: Middle East Institute, [2010]. p.75-77.

HALLIDAY, Fred. The Middle East in International Relations: Power, Politics and Ideology. Nova Iorque: Cambridge University Press, 2005.

HERB, M. All in the Family: Absolutism, Revolution, and Democracy in the Middle Eastern Monarchies. Albany: State University of Nova Iorque Press, 1999. 


\section{Conjuntura Austral}

HUBBARD, B. King Salman of Saudi Arabia Names Mohammed bin Nayef Next in Line of Succession. The New York Times. Nova Iorque, 29 abr. 2015a. Disponível em: <http://www.nytimes.com/2015/04/29/world/middleeast/kingsalman-of-saudi-arabia-changes-line-of-succession.html>. Acesso em: 4 maio 2015 .

HUBBARD, B. Saudi Arabia's Succession Line Is Set, but the Nation's Path Remains Uncertain. The New York Times. Nova Iorque, 23 jan. 2015b. Disponível em: $<$ http://www.nytimes.com/2015/01/24/world/middleeast/king-abdullah-saudiarabia-funeral.html?_r=0>. Acesso em: 6 abr. 2015.

HUBBARD, B.; KRIKPATRICK, D. D. Saudi Succession Hints at Shift in Foreign Role. The New York Times. Nova Iorque, 26 jan. 2015. Disponível em: $<$ http://www.nytimes.com/2015/01/27/world/middleeast/saudi-succession-hintingat-shift-in-foreign-role.html>. Acesso em: 6 abr. 2015.

IHS JANE’S. Country profile Saudi Arabia. Englewood: HIS Jane’s, 2009a.

IHS JANE'S. Country profile Yemen. Englewood: HIS Jane's, 2009b.

KECHICHIAN, J. A. Succession in Saudi Arabia. Nova Iorque: Palgrave Macmillan, 2001.

KECHICHIAN, J. A. The kingdom's reformist monarch: Abdullah bin Abdulaziz (1924-2015). Al Jazeera. Doha, 5 jan. 2015. Disponível em:

$<$ http://www.aljazeera.com/indepth/opinion/2015/01/kingdom-reformist-monarchabdull-20151310120684789.html>. Acesso em: 6 abr. 2015.

KHATID, L. The regional impacts of Saudi succession. Al Jazeera. Doha, 25 jan. 2015. Disponível em: < http://www.aljazeera.com/news/2015/01/regional-impactssaudi-succession-20151694233783822.html>. Acesso em: 6 abr. 2015.

LONG, D. E.; MAISEL, S. The Kingdom of Saudi Arabia. Gainesville: University Press of Florida, 2010.

MARANDI, S. M. Yemen's shock and awe. Al Jazeera. Doha, 2 abr. 2015. Disponível em: <http://www.aljazeera.com/indepth/opinion/2015/04/yemen-iran-houthisconflict-saudi-150402065023680.html>. Acesso em: 6 abr. 2015.

NAAR, I. Who are Saudi Arabia's new crown princes? Al Jazeera. Doha, 24 jan. 2015. Disponível em: $<$ http://www.aljazeera.com/news/2015/01/saudis-crown-princes150124083039820.html>. Acesso em: 6 abr. 2015. 


\section{Conjuntura Austral}

NEW Saudi king seeks to reassure on succession and policy. Reuters. Londres, 23 jan. 2015. Disponível em: <http://www.reuters.com/article/2015/01/23/us-saudisuccession-funeral-idUSKBN0KW0N020150123>. Acesso em: 6 abr. 2015.

REARDON, M. Saudi Arabia draws the line in Yemen. Al Jazeera. Doha, 26 mar. 2015a. Disponível em:

$<$ http://www.aljazeera.com/indepth/opinion/2015/03/saudi-arabia-draws-lineyemen-150326134045949.html>. Acesso em: 6 abr. 2015.

REARDON, M. Yemen over the edge. Al Jazeera. Doha, 24 mar. 2015b. Disponível em: <http://www.aljazeera.com/indepth/opinion/2015/03/yemen-edge150324052332887.html>. Acesso em: 6 abr. 2015.

REED, S.; KRAUSS, C. New King in Saudi Arabia Unlikely to Alter Oil Policy. The New York Times. Nova Iorque, 23 jan. 2015. Disponível em:

$<$ http://www.nytimes.com/2015/01/24/business/international/king-abdullahsdeath-unlikely-to-upset-saudi-oil-goals-analysts-say.html>. Acesso em: 6 abr. 2015.

SALMAN takes Saudi throne after King Abdullah dies. Deutsche Welle. Bonn, 23 jan. 2015. Disponível em: <http://www.dw.de/salman-takes-saudi-throne-after-kingabdullah-dies/a-18210367>. Acesso em: 6 abr. 2015.

SAUDI ARABIA. Basic Law of Government. Riad, 1993.

SAUDI ARABIA. The Allegiance Institution Law. Riad, 2006.

SAUDI Arabia won't change after King Abdullah's death. Pravda. Moscou, 23 jan. 2015a. Disponível em: <http://english.pravda.ru/world/asia/23-01-2015/129599saudi_king_abdullah_dies-0/>. Acesso em: 6 abr. 2015.

SAUDI King Salman cements hold on power. Al Jazeera. Doha, 30 jan. $2015 b$.

Disponível em: <http://www.aljazeera.com/news/middleeast/2015/01/saudi-kingsalman-cements-hold-power-150130032136422.html>. Acesso em: 6 abr. 2015.

STEPHENS, M. Saudi Arabia after King Abdullah. Al Jazeera. Doha, 23 jan. 2015a. Disponível em: <http://www.aljazeera.com/indepth/opinion/2015/01/saudi-arabiaking-abdullah-201511391548669733.html>. Acesso em: 6 abr. 2015.

STEPHENS, M. Yemen is a defining moment for King Salman. Al Jazeera. Doha, 27 mar. 2015b. Disponível em:

$<$ http://www.aljazeera.com/indepth/opinion/2015/03/yemen-defining-momentking-salman-150327065530744.html>. Acesso em: 6 abr. 2015. 


\section{Conjuntura Austral}

SULLIVAN, K.; SLY, L. Saudi King Abdullah's death sets up complex succession process. The Washington Post. Washington, 22 jan. 2015. Disponível em: $<$ http://www.washingtonpost.com/world/middle_east/saudi-king-abdullahs-deathsets-up-complex-succession-process/2015/01/22/340e0a9c-a28e-11e4-9f89561284a573f8_story.html>. Acesso em: 6 abr. 2015.

THE World's 25 Biggest Oil Companies. Forbes. Jersey City, 2012. Disponível em: $<\mathrm{http}$ ://www.forbes.com/pictures/mef45glfe/1-saudi-aramco-12-5-million-barrelsper-day-3/>. Acesso em: 6 abr. 2015.

YEMEN'S president Ali Abdullah Saleh cedes power. BBC. Londres, 27 fev. 2012. Disponível em: <http://www.bbc.com/news/world-middle-east-17177720>. Acesso em: 6 abr. 2015.

WHILE nations such as Germany and France sent lower-ranking officials, Obama cut short his trip in India, and attended Abdullah's funeral himself. The Jerusalem Post. Jerusalem, 2 jan. 2015. Disponível em:

$<$ http://www.jpost.com/Opinion/Saudi-succession-389672>. Acesso em: 6 abr. 2015.

WHO is King Salman, Saudi Arabia's new ruler? Haaretz. Tel Aviv, 23 jan. 2015. Disponível em: $<$ http://www.haaretz.com/news/middle-east/1.638640 $>$. Acesso em: 6 abr. 2015.

Recebido em 06 de abril de 2015. Aprovado em 06 de maio de 2015. 


\title{
Conjuntura Austral
}

\section{RESUMO}

No início do ano de 2015, dois importantes eventos afetaram a Península Arábica, alterando os governantes de Arábia Saudita e Iêmen. A morte do rei saudita Abdullah em janeiro pôs fim a um reinado de dez anos, ainda que o monarca governasse desde 1995 . Enquanto isso, a rebelião dos houthis no vizinho ao sul derrubou em março o presidente iemenita Hadi, no poder desde 2012. A presente análise de conjuntura busca avaliar os efeitos do processo sucessório em Riad sobre os rumos de sua política doméstica, externa e regional e a assertiva saudita participação na crise desencadeada no Iêmen.

Palavras Chave: Península Arábica; Arábia Saudita; Iêmen;

\begin{abstract}
In the beginning of 2015, two important events affected the Arabian Peninsula, changing the Saudi and Yemeni rulers. Saudi king Abdullah's death ended a decadelong reign, although he ruled since 1995. Meanwhile, the Houthi rebellion in its Southern neighbor toppled Yemeni president Hadi, who rose to power in 2012. This situational analysis seeks to evaluate Riyadh's succession process' effects on its domestic, foreign and regional policies and Saudi assertive participation in the Yemeni crisis.
\end{abstract}

Keywords: Arabian Peninsula; Saudi Arabia; Yemen; 


\title{
Conjuntura Austral
}

\section{POLÍTICA AFRICANA DO BRASIL: MUDANÇA ENTRE LULA E DILMA?}

\section{Brazil's Africa Policy: Change between Lula and Dilma?}

\author{
Guilherme Ziebell de Oliveira ${ }^{1}$
}

\section{Introdução}

Os dois mandatos do governo Lula marcaram uma mudança significativa na política externa brasileira para a África. Depois de um longo distanciamento, as relações entre o país e o continente abandonaram a retórica, ganhando um novo impulso (VISENTINI, 2009). Entre 2003 e 2010, o Brasil ampliou significativamente sua participação na África. O país abriu (ou reabriu) embaixadas em dezoito países do continente (passando de 18 para 36 embaixadas), no que foi correspondido pelos países africanos, que abriram 13 novas embaixadas em Brasília, atingindo um total de 29 países com representação no Brasil. $\mathrm{O}$ avanço, todavia, não foi apenas diplomático. $\mathrm{O}$ volume de comércio entre o Brasil e a África cresceu consideravelmente, passando de US\$ 5 bilhões, em 2002, para US\$ 26 bilhões em 2008, e uma série de iniciativas foram criadas (como a Cúpula América do Sul-África) ou retomadas (como a Zona de Paz e Cooperação do Atlântico Sul - Zopacas - e a Comunidade dos Países de Língua Portuguesa - CPLP) (AMORIM, 2010).

Após oito anos de intensa interação com o continente, nos quais o presidente brasileiro realizou 13 viagens à África, visitando 28 países (alguns deles mais de uma vez) (BRASIL, 2011d) e o chanceler Celso Amorim esteve no continente 66 vezes, participando de eventos oficiais em 25 países diferentes (BRASIL, 2011a), a eleição de Dilma Rousseff e a substituição do ministro Amorim por Antônio Patriota geraram uma série de expectativas em relação aos rumos que seriam adotados na política externa do

\footnotetext{
${ }^{1}$ Doutorando do Programa de Pós-Graduação em Ciência Política da Universidade Federal do Rio Grande do Sul (PPGPOL/UFRGS). Mestre em Estudos Estratégicos Internacionais pelo Programa de Pós-Graduação em Estudos Estratégicos Internacionais da UFRGS (PPGEEI/UFRGS). Graduado em Relações Internacionais pela UFRGS. (oliveiragz@gmail.com).
} 


\section{Conjuntura Austral}

país, inclusive para a África. Enquanto, para alguns analistas, houve uma continuidade no tratamento dispensado ao continente (DAUVERGNE; FARIAS, 2012), para outros, teria havido uma mudança na relação com a África (PEREIRA, 2012), refletida, entre outros, em uma diminuição dos contatos com os países do continente - com visitas da presidenta a apenas seis países africanos e de seus chanceleres (Patriota e Figueiredo em conjunto) a quinze. Após pouco mais de quatro anos, entretanto, pouco se produziu, na academia, em termos de reflexões acerca da política externa do governo Dilma, sobretudo em relação ao continente africano.

Esse artigo, nesse contexto, visa a analisar a política africana dos governos Lula e Dilma, de forma a avaliar se houve, realmente, uma mudança e, em caso afirmativo, qual foi a sua profundidade, de acordo com os níveis definidos por Charles F. Hermann (1990). Para tanto, o trabalho será dividido em três seções, além dessa introdução. Na primeira seção, serão analisadas as realizações da política externa brasileira para a África nos governos Lula (2003-2010) e Dilma Rousseff (2011-2014). Em seguida, avaliar-se-ão, sobretudo a partir dos trabalhos de Hermann (1990) e Ricardo Sennes (2003), os conceitos de Mudança de Política Externa e de Matriz de Política Externa, cruciais para o propósito desse artigo. Por fim, a última seção apresentará as conclusões finais acerca do tema estudado.

\section{A retomada de importância da África para o Brasil}

O Brasil começou a construir uma política externa africana, lentamente, a partir da década de 1960, através da Política Externa Independente (PEI) lançada durante o governo Jânio Quadros. Esta atingiu o seu auge na década de 1970 - durante o governo de Ernesto Geisel - e, na década de 1990, vivenciou seu maior declínio, com a adoção do conceito de seletividade nas relações com o continente ${ }^{2}$ (SILVA, 2010). A partir do governo Lula, entretanto, houve uma retomada de ímpeto na política externa brasileira para a África. Além dos laços históricos e étnicos que unem o Brasil ao continente africano, a retomada de importância da África para a política externa brasileira se

\footnotetext{
2 A menor importância da África para a política externa do governo de Fernando Henrique Cardoso também fica expressa pelo número de países do continente por ele visitados ao longo de seus dois mandatos: apenas três (NETO, 2012).
} 


\section{Conjuntura Austral}

deveu, sobretudo, a aspectos econômicos e estratégicos (LECHINI, 2008). O continente, longe da imagem de estagnação que predominava na década anterior, passou a ser percebido como um elemento essencial para a inserção internacional brasileira (VISENTINI, 2009).

Nesse contexto, de acordo com Saraiva (2012), o novo momento vivido pela África no século XXI coincidiu com um novo momento vivenciado pelo Brasil, o que permitiu a superação da dualidade entre pessimistas, que defendiam o isolamento da África e a orientação da política externa brasileira para os grandes centros hegemônicos, e otimistas, que insistiam que o Brasil deveria retornar às rotas do Atlântico Sul para restabelecer as conexões que existiam com o continente africano, promovendo uma "aproximação" das margens do Atlântico Sul. A política externa do governo Lula, assim, buscou, entre outros, aliar a manutenção de boas relações com parceiros tradicionais (como os EUA e a França, por exemplo) à diversificação de parcerias, aumentando a sua participação em espaços pouco ocupados pela diplomacia brasileira ao longo da década anterior (SILVA, 2010).

A África, dessa forma, foi incluída entre as prioridades da política externa brasileira. Assim, o presidente Lula, em seu discurso de posse, ressaltou que o continente teria um espaço destacado na agenda de política externa brasileira (SILVA, 2003). O maior engajamento com a África se daria, portanto, através de uma relação entre iguais, em um esforço comum de superação das dificuldades sociais e econômicas mútuas (SARAIVA, 2012). Além disso, ele seria, também, uma forma de elevar o perfil internacional do Brasil, garantindo o acesso a novos mercados e a vantajosas oportunidades econômicas, além de maior influência em foros multilaterais (BRASIL, 2011a).

Em grande parte de suas visitas aos países africanos, Lula foi acompanhado por comitivas de empresários brasileiros, interessados em possibilidades de expansão do campo de atuação de suas empresas. O Banco Nacional de Desenvolvimento Econômico e Social (BNDES), nesse contexto, serviu como financiador da internacionalização das empresas brasileiras, fornecendo empréstimos às empresas nacionais que atuavam em setores estratégicos (como infraestrutura, mineração e energia) em países africanos (PINHO, 2013). Isso foi fundamental para que empresas 


\section{Conjuntura Austral}

como Petrobrás, Odebrecht, Camargo Correa, Andrade Gutierrez e Queiroz Galvão, responsáveis, entre outros, pela prestação de serviços e realização de obras de infraestrutura se instalassem (ou consolidassem sua presença) em diversos países do continente, fortalecendo os seus laços com o Brasil (MIYAMOTO, 2011).

Além disso, a interação com o Brasil levou aos países africanos diversos novos elementos, diferentes daqueles trazidos por outros parceiros internacionais (como China, Índia e EUA, por exemplo), ligados, sobretudo, ao combate à pobreza e às epidemias (principalmente o vírus do HIV/AIDS), além da introdução e do desenvolvimento de tecnologias melhor adaptadas à sua realidade e de uma importante parceria em foros multilaterais (VISENTINI, 2009). Nesse contexto, destaca-se que diversos países africanos demonstraram interesse na implementação de programas inspirados no Fome Zero e no Bolsa Família, sobretudo devido à efetividade demonstrada por eles no Brasil. Assim, a partir de 2005, o Brasil passou a fornecer apoio técnico para governos africanos interessados na implementação de programas de transferência de renda. Além das missões realizadas por representantes do Ministério do Desenvolvimento Social e Combate à Fome (MDS) ao continente africano, representantes de Gana, Guiné-Bissau, Moçambique, Nigéria, África do Sul e Zâmbia realizaram visitas ao Brasil, como forma de estudar a implementação e o gerenciamento de tais programas (STOLTE, 2012).

É importante ressaltar, ainda, entre as iniciativas de aproximação do governo brasileiro com os países africanos, a criação de um escritório da Empresa Brasileira de Pesquisa Agropecuária (Embrapa) em Gana, o estabelecimento de uma fazenda-modelo para a produção de algodão no Mali, e a instalação de centros de formação profissional, em parceria com o Serviço Nacional de Aprendizagem Industrial (SENAI), em GuinéBissau e Cabo Verde. Além disso, o governo brasileiro firmou acordos de serviços aéreos com países africanos, como forma de facilitar a criação de rotas aéreas entre as duas regiões e fomentar o fluxo de bens e pessoas entre o Brasil e a África (BRASIL, 2011a).

Ainda, o governo brasileiro manteve o apoio aos processos de pacificação e reconstrução, concedeu assistência e crédito em diversas áreas e também perdoou a dívida externa de diversos países africanos. Além disso, foram criados e reforçados 


\section{Conjuntura Austral}

projetos de cooperação nas áreas de educação (como o PEC-G, o PEC-PG, ${ }^{3}$ e a Unilab ${ }^{4}$ ) e de saúde, com o estabelecimento de 53 atos bilaterais com 22 países na área da saúde. Destacam-se, entre esses, projetos de auxílio ao combate à malária (em Angola, Camarões, Guiné-Bissau e Quênia) e ao HIV/AIDS (no Quênia, São Tomé e Príncipe, Botsuana, Zâmbia, Burundi, Cabo Verde e Guiné-Bissau) e para o diagnóstico da anemia falciforme (em Angola, Benin, Senegal e Gana) (BRASIL, 2011c).

Outro ponto importante da aproximação brasileira com a África ao longo do governo Lula pode ser visto na realização das Cúpulas América do Sul-África (ASA). Em uma visita ao Brasil, em 2005, o então presidente nigeriano, Olusegun Obasanjo, manifestou interesse no estabelecimento de um mecanismo capaz de aproximar os países africanos do Brasil. O presidente brasileiro se mostrou favorável à ideia, mas sugeriu que a proposta englobasse também os demais países sul-americanos, como forma de dar maior peso a tal mecanismo. Como resultado dessa interação, em 2006 foi realizada a I Cúpula América do Sul-África (ASA), em Abuja, Nigéria, reunindo os 65 países das duas regiões e estabelecendo, entre outros, a realização de uma Cúpula a cada dois anos, além de encontros de chanceleres entre cada Cúpula e outros encontros, inclusive ministeriais setoriais. Em 2009, a II Cúpula América do Sul-África foi realizada em Isla Margarita, na Venezuela (BRASIL, 2011a).

Em termos de defesa, é importante ressaltar o relançamento, em 2007, da Zopacas, ${ }^{5}$ além do estabelecimento de diversos acordos de cooperação em defesa com

\footnotetext{
3 O Programa de Estudantes-Convênio de Graduação (PEC-G) foi criado oficialmente em 1965. Ele possibilita que estudantes de países em desenvolvimento com os quais o Brasil mantém acordo educacional, cultural ou científico-tecnológico realizem sua graduação em Instituições de Ensino Superior brasileiras. O Programa de Estudantes-Convênio de Pós-Graduação (PEC-PG) foi criado em 1981, sendo atualizado em 2006. Ele oferece bolsas de estudo para estudantes de países em desenvolvimento para formação em cursos de mestrado e doutorado em Instituições de Ensino Superior brasileiras.

4 Em 2008, foi criada a Comissão de Implantação da Universidade da Integração Internacional da Lusofonia Afro-Brasileira (Unilab). A ideia era uma universidade no Brasil alinhada à integração com a África, especialmente com os países africanos membros da CPLP. Em 2010, a Unilab foi instituída como Universidade Pública Federal e, em maio de 2011, foi inaugurada, contando com campi no Ceará e na Bahia.

5 A Zopacas, criada na década de 1980, realizou diversas reuniões ao longo da década de 1990 e depois de um longo período de inatividade - que quase custou sua existência - foi revitalizada a partir de uma reunião realizada em Luanda, por iniciativa de Angola, em 2007 (PENHA, 2011). Visentini (2009), por sua vez, destaca o potencial da Zopacas de servir como espaço de interação entre diversos processos de
} 


\section{Conjuntura Austral}

sete países africanos (África do Sul, Angola, Moçambique, Namíbia, Guiné Equatorial, Nigéria e Senegal) e a ratificação de um acordo com Cabo Verde, que fora assinado em 1995. Em termos práticos, destaca-se a criação, pelo Brasil, de um Centro de Formação de Forças de Segurança na Guiné-Bissau; a doação de embarcações e uniformes para as Marinhas de São Tomé e Príncipe, Guiné-Bissau e Namíbia; o envio de instrutores brasileiros para um Centro de Aperfeiçoamento para Ações de Desminagem e Despoluição no Benim; o apoio brasileiro à criação do Corpo de Fuzileiros Navais da Namíbia; e a colaboração para a reforma do setor de segurança e defesa bissauguineense (BRASIL, 2011b).

A reaproximação com o continente africano e, sobretudo, com a África Ocidental, tem se mostrado extremamente importante para o Brasil. Economicamente, percebe-se um crescimento expressivo do intercâmbio comercial. É importante destacar a atuação da Petrobras, que é o parceiro mais importante da Nigéria no setor petrolífero, além de estar presente também em Angola e em outros quatro países africanos, e também de empresas da área de defesa, como a Empresa Brasileira de Aeronáutica (Embraer) e a Empresa Gerencial de Projetos Navais (Emgepron), presentes e atuantes na África, tanto na vertente comercial quanto na de difusão do conhecimento tecnológico e de realização de projetos conjuntos (BRASIL, 2011b; MIYAMOTO, 2011).

Ainda que o comércio com a África, mesmo após essa significativa expansão, tenha ficado bastante distante do observado com a América do Sul, com os EUA, com a Europa ou com os países asiáticos, é inegável que houve uma inflexão na agenda de política externa brasileira, que deixou de privilegiar, através de parcerias seletivas, apenas as ligações com as grandes potências, dando maior evidência ao continente africano. Nesse sentido, destaca-se que, em 2009, 50\% dos projetos de desenvolvimento internacional do Brasil, gerenciados pela Agência Brasileira de Cooperação ( $A B C)$, eram destinados a países africanos e em 2010 esse percentual aumentou para aproximadamente 60\%, totalizando mais de US\$ 22 milhões (BANCO MUNDIAL; IPEA, 2011) No total, no período compreendido entre 2003 e 2010, o Brasil estabeleceu

integração do Atlântico Sul, favorecendo o relacionamento entre Mercosul e ECOWAS/CEDEAO, por exemplo. 


\section{Conjuntura Austral}

481 projetos de cooperação ${ }^{6}$ com os países do continente africano, sendo 420 concluídos ainda dentro deste período (BRASIL, 2015a).

Em termos político-diplomáticos, destaca-se que o Brasil, junto às nações africanas, realizou esforços que buscavam reduzir assimetrias, garantir o acesso a novos mercados e também aumentar o seu protagonismo no cenário internacional. Nesse contexto, o apoio recorrente da Comunidade dos Países de Língua Portuguesa (CPLP), obtido pelo Brasil, em suas demandas de ocupar um assento de membro permanente no Conselho de Segurança da Organização das Nações Unidas se mostrou bastante expressivo (MIYAMOTO, 2011).

Dilma Rousseff assumiu a presidência do Brasil em janeiro de 2011 e, junto com ela, Antônio Patriota ${ }^{7}$ assumiu o Ministério das Relações Exteriores, substituindo Celso Amorim. Diversas expectativas surgiram em relação aos rumos que seriam tomados na política externa do novo governo, especulando-se sobre mudanças ou sobre a continuidade da política anterior. Ainda no primeiro ano de governo, Dilma realizou sua primeira visita ao continente africano, dando indícios de que a política anterior seria mantida. Após participar da reunião do IBAS na África do Sul, a presidenta visitou Moçambique e Angola. No mesmo ano Dilma designou o ex-presidente Lula como representante oficial do Brasil na $17^{\mathrm{a}}$ Cúpula da União Africana (UA) realizada na Guiné Equatorial (BANCO MUNDIAL; IPEA, 2011), e promoveu a criação do "Grupo África". O grupo, composto por diferentes ministérios além de especialistas e executivos do setor privado, tinha por objetivo associar investimentos e vendas brasileiras a programas de desenvolvimento locais, como forma de proporcionar ganhos maiores ao continente africano, além de coordenar a atuação das empresas brasileiras no continente, garantindo um projeto geral para o país (CABRAL, 2011).

Ao longo de do primeiro ano de governo, foram estabelecidos 81 novos projetos de cooperação com países do continente, entre os quais se destacam a capacitação de militares em Guiné-Bissau, Senegal e Benim e um projeto para a modernização da previdência social de Moçambique (BRASIL, 2015a). Além disso, em junho daquele

\footnotetext{
6 Os projetos de cooperação são divididos pela ABC em quatro categorias: cooperação Sul-Sul, cooperação trilateral, cooperação trilateral com organismo e cooperação de bloco.

${ }^{7}$ Patriota, por sua vez, foi substituído, em agosto de 2013, por Luiz Alberto Figueiredo.
} 


\section{Conjuntura Austral}

ano, o ex-ministro do governo Lula, José Graziano, foi eleito Diretor-Geral da Organização das Nações Unidas para a Alimentação e a Agricultura (FAO), em grande medida por conta do apoio dado pelos países africanos (SARAIVA, 2012).

Durante o ano seguinte, a presidenta não realizou visitas ao continente africano, mas 37 projetos de cooperação foram estabelecidos com países africanos. Entre esses, destacam-se um novo projeto de capacitação de militares no Senegal e também em Moçambique, Cabo Verde, São Tomé e Príncipe, Nigéria e Angola e o apoio técnico para realização de eleição presidencial na Guiné-Bissau (BRASIL, 2015a). Também em 2012, o Brasil firmou um acordo de cooperação com Moçambique, comprometendo-se em auxiliar o país africano a implementar o programa "Luz para Todos", que tem como objetivo garantir o acesso à eletricidade para residências e empresas nas áreas rurais e que, no Brasil, desde 2003, já garantiu o acesso à eletricidade a mais de três milhões de famílias (PINHO, 2013). No total, ao longo daquele ano, o BNDES forneceu US\$ 642 milhões em financiamento para empresas brasileiras atuantes no continente, o que representou um aumento de 46\% em relação ao ano anterior (MARULL, 2013). Além disso, no mesmo ano o Brasil acertou a venda de aviões Super Tucano para Angola, Burkina Faso e Mauritânia (SILVEIRA, 2012).

Em 2013, Dilma retomou a agenda de visitas ao continente africano. Além de visitar a Guiné Equatorial no contexto da III Cúpula América do Sul-África, a presidenta realizou visitas oficiais à Nigéria, à África do Sul (para a V Cúpula de Chefes de Estado e de Governo dos BRICS) e à Etiópia (onde participou das celebrações dos 50 anos da União Africana). Além disso, foi aberta a $37^{\mathrm{a}}$ embaixada do país no continente (em Lilongwe, Malauí), ${ }^{8}$ o programa PEC-G foi reforçado (através do Decreto Presidencial n. 7.948, que conferiu maior força jurídica ao seu regulamento), foram estabelecidos novos projetos de capacitação militar com Angola, Moçambique, São Tomé e Príncipe e Senegal, e a presidenta anunciou, na Etiópia, o perdão e a reestruturação de US\$ 900 milhões em dívidas de países africanos com o Brasil ${ }^{9}$

\footnotetext{
${ }^{8}$ O Brasil contava, em 2013, com 33 embaixadas de países africanos em Brasília, quatro a mais do que no final do governo Lula (GARCIA, 2013).

9 Os países atingidos pela decisão foram Congo, Costa do Marfim, Gabão, Guiné-Bissau, Guiné Equatorial, Mauritânia, São Tomé e Príncipe, República Democrática do Congo (RDC), Senegal,
} 


\section{Conjuntura Austral}

(MARULL, 2013). Ainda, no mesmo ano uma representação do BNDES para a África foi criada na África do Sul, e uma nova venda de aviões Super Tucano foi realizada, dessa vez para o Senegal (BNDES, 2013; VILLELA, 2013).

Em 2014, último ano de seu primeiro mandato, a presidenta Dilma Rousseff não realizou visitas ao continente africano. Ainda assim, novos projetos de capacitação militar foram estabelecidos com Angola, Moçambique, São Tomé e Príncipe e Senegal, bem como um projeto de cooperação com a Costa do Marfim para o desenvolvimento sustentável do setor de pesca e aquicultura no país, e um projeto de cooperação triangular com Angola e a FAO (BRASIL, 2014; 2015a).

Fica claro, assim, que há, a partir de 2003, a colocação da África em um espaço destacado da agenda de política externa brasileira. Isso se deu a partir da construção de um discurso e de políticas que se direcionavam não apenas aos países africanos individualmente, mas também para o continente como um todo, movimento que se insere em uma estratégia brasileira de fortalecimento do multilateralismo (RIZZI et al, 2011). Nesse contexto, a ideia de Saraiva (2012), de que a nova política africana, inaugurada a partir de 2003, já se consolidou como uma política de Estado, ganha força.

\section{Matriz e Mudança de Política Externa}

Em geral, a análise da política externa de um país se dá a partir do recorte em diferentes governos, buscando-se semelhanças e diferenças que são associadas, em grande medida, a cada período presidencial. Ricardo Sennes (2003), por sua vez, propõe um modelo diferente de análise. A partir do entendimento de que as percepções, perspectivas, estratégias e valores que sustentam a política externa de um país costumam variar em menor grau do que os mandatos presidenciais, podendo haver, em geral, apenas uma variação no estilo de condução diplomática de um governo para outro, o autor propõe a noção de matriz de política externa.

Segundo o autor, a ideia de matriz "diz respeito aos contornos mais gerais da política externa de um país e busca determinar a forma pela qual ele concebe a dinâmica do sistema internacional" (SENNES, 2003, p. 36). Dessa forma, a matriz da política

Sudão, Tanzânia e Zâmbia, sendo a RDC e a Tanzânia os detentores das maiores dívidas, que foram reestruturadas 


\section{Conjuntura Austral}

externa de um Estado não seria o reflexo de um núcleo burocrático específico (não sendo produto exclusivo de um determinado governo ou governante), mas sim um conjunto de opções, concepções e estratégias em um nível de agregação de ordem nacional, generalizável a um determinado país. Nesse sentido, a noção de matriz leva em consideração condicionamentos e opções estruturais, que, em geral, sofrem mudanças em espaços de tempo maiores do que a duração dos governos, sobretudo nos regimes presidencialistas. Assim, a determinação da matriz pela qual se baseiam as posturas externas de um Estado, portanto, implicaria na identificação dos elementos que determinam a sua projeção internacional.

Dilma Rousseff foi Ministra (de Minas e Energia e Ministra-Chefe da Casa Civil) durante o governo Lula, além de ter sido a responsável por chefiar o Programa de Aceleração do Crescimento (PAC) do Governo Federal no período e de ter recebido o apoio de Lula em sua candidatura à presidência (BERTAZZO, 2012). Levando isso em consideração, e adotando a ideia de matriz de política externa, podemos afirmar que, em grande medida, o governo Rousseff representou uma continuação da matriz em que estava inserido o governo Lula, ${ }^{10}$ o que, todavia, não exclui a possibilidade de mudanças na concepção e na condução da política. Nesse sentido, o trabalho de Charles Hermann (1990) é de grande utilidade. Nele o autor busca entender quais fatores levam os Estados a mudarem suas políticas externas. Segundo ele, grande parte das mudanças que ocorrem nas políticas externas dos países se dão quando novos governos, com diferentes alinhamentos e/ou percepções do cenário e das agendas internacionais, assumem o poder, sendo estas, em geral, bastante significativas. Hermann, entretanto, se foca na análise das mudanças que ocorrem sem que haja uma mudança em quem governa o país (o que ele chama de mudanças autocorretivas).

Ainda que a eleição de Dilma Rousseff tenha representado, formalmente, uma mudança de governo, apoiando-se na noção de matriz de política externa e também no fato de, em grande medida, ambos os governos terem o mesmo alinhamento político e percepções do cenário e das agendas internacionais (e também nacionais), pode-se

\footnotetext{
10 O governo Lula, segundo Silva (2010, p.18), “[operava] sobre a matriz de inserção internacional do Brasil que se esboçou já no final do governo Cardoso, mas que ganhou contornos mais nítidos apenas com a ascensão do novo governo".
} 


\section{Conjuntura Austral}

considerar que há uma continuidade no governo, ainda que ele seja comandado por outro chefe de Estado. A partir dessa percepção, o trabalho de Hermann torna-se uma ferramenta útil para avaliar se houve, de fato, mudanças na política externa brasileira para o continente africano a partir do governo Dilma, bem como qual a sua profundidade.

Hermann (1990) divide as mudanças autocorretivas em quatro diferentes níveis. O primeiro nível seria o de Mudanças de Ajuste, que diria respeito a uma mudança no esforço com que se busca determinado objetivo, sem que haja mudança nos objetivos ou mesmo na maneira através da qual eles são buscados. $O$ segundo nível seria o de Mudanças de Programa, representado por mudanças nos métodos ou meios utilizados para atingir um determinado objetivo, que permaneceria inalterado. O terceiro nível seria o de Mudança de Objetivo, no qual haveria uma substituição ou o abandono do objetivo inicial da política externa. Por fim, o quarto nível, o mais radical de todos, seria o de Mudança de Orientação Internacional, no qual seriam realizadas mudanças em diversas políticas ao mesmo tempo, implicando em uma mudança no papel internacional do ator em questão.

Ainda, para o autor, haveria quatro diferentes fontes de mudanças significativas de política externa, as quais poderiam interagir, sendo ao mesmo tempo causa e efeito umas das outras e, assim, gerar as mudanças. A primeira seria a realizada pelo líder, que imporia sua própria visão à política externa. A segunda seria a defesa burocrática, que diria respeito às pressões realizadas por grupos dentro do governo (agrupados uniformemente ou dissipados) interessados em uma determinada mudança na política externa. A terceira seria a reestruturação doméstica, que ocorreria quando os grupos que sustentam o governo mudassem a suas opiniões em relação a determinado assunto ou mesmo sua composição. A quarta fonte seriam os choques externos, eventos internacionais responsáveis por impactos significativos e impossíveis de serem ignorados pelo Estado em questão. Essas fontes, todavia, não gerariam, independentemente, mudanças significativas de política externa, tendo o processo de tomada de decisão do governo um papel fundamental nessa alteração, já que este atuaria como um facilitador e/ou dificultador do processo de mudança de política externa. 


\section{Conjuntura Austral}

O ex-presidente Lula, em seus três primeiros anos de governo (2003-2005) visitou 12 países africanos (São Tomé e Príncipe, Angola, Moçambique, Namíbia e África do Sul, em 2003; São Tomé e Príncipe, Gabão e Cabo Verde, em 2004; e Nigéria, Gana, Guiné-Bissau, Senegal e Camarões, em 2005). Dilma Rousseff, por sua vez, em um período equivalente (2011-2013), visitou apenas seis países africanos ${ }^{11}$ (África do Sul, Moçambique e Angola, em 2011, e Nigéria, Guiné Equatorial e Etiópia, em 2013). Em grande medida, essa menor presença da presidenta no continente africano foi um dos principais motivos para que se criasse uma ideia de que o continente teria menos espaço - e importância - na política externa brasileira.

Cabe destacar, todavia, que a conjuntura vivida pelos dois governos foi bastante diferente. Internamente, o governo Dilma enfrentou um contexto mais difícil que seu antecessor. A partir do final de 2010 e início de 2011, começaram a ficar cada vez mais claros os limites ao modelo de crescimento baseado no mercado interno e na redistribuição da renda, combinado com a manutenção de juros elevados e apreciação cambial, o que passou a exigir esforços redobrados do governo federal (TEIXEIRA; PINTO, 2012). Além disso, a renovação da infraestrutura nacional para a Copa do Mundo de futebol de 2014 também se mostrou (e tem se mostrado) um importante desafio para o governo.

Além das mudanças no contexto interno, Dilma Rousseff também enfrentou um ambiente externo mais hostil que Lula, com os efeitos da crise econômica mundial tendo sido sentidos de forma mais acentuada no seu governo (PEREIRA, 2012). Além disso, ela também teve de enfrentar a chamada "Primavera Árabe", bem como seus desdobramentos no continente africano (queda de regimes, instabilidade e renovada ingerência das potências ocidentais na região, entre outros). Esses fatores, em grande medida, contribuíram para que o governo Rousseff deixasse a política externa em um segundo plano (ou ao menos desse menos enfoque a ela do que o governo anterior ${ }^{12}$ ), detendo-se com mais atenção à política interna. Ainda assim, o governo Rousseff deu

11 Cabe ressaltar, todavia, que Lula, nos três primeiros anos de seu segundo mandato (2007-2009), também realizou visitas a apenas seis países africanos: Burkina Faso, República do Congo, África do Sul, Angola, Moçambique e Líbia (BRASIL, 2011d).

12 Diferentemente dos dois presidentes anteriores, Dilma Rousseff deu menos ênfase à "diplomacia presidencial". Isso se refletiu não só no menor número de visitas ao continente africano, mas em um menor número de visitas oficiais da presidenta a outros países como um todo. 


\section{Conjuntura Austral}

continuidade a 61 projetos de cooperação com países africanos que haviam sido estabelecidos através da ABC durante o governo Lula, além de dar início a 156 outros (BRASIL, 2015a).

Além disso, alguns autores apontam que a criação de um grande número de projetos de cooperação com os países africanos durante o governo Lula sobrecarregou a capacidade do Estado brasileiro (tanto em termos de recursos humanos quanto financeiros), além de ter gerado certa sobreposição institucional, o que teria contribuído para dificultar a avaliação da correlação de custos e benefícios dos projetos, e criado entraves ao desenvolvimento de projetos de longo prazo (ALVES, 2013). A criação de um menor número de projetos de cooperação durante o governo Dilma estaria, dessa forma, inserida em um contexto de melhor organização, planejamento e estruturação dos projetos desenvolvidos, e de consolidação das iniciativas lançadas anteriormente, como destacado por Antônio Patriota (BACHEGA, 2014).

Nesse sentido, pode-se perceber que, em relação à África, o governo Rousseff deu uma significativa ênfase à cooperação na área de Defesa. Enquanto no governo Lula apenas cerca de $1 \%$ dos projetos de cooperação estabelecidos via $\mathrm{ABC}$ foram nesta área, ${ }^{13}$ no governo de Dilma Rousseff esta proporção saltou para cerca de $16 \%$ (BRASIL, 2015a). ${ }^{14} \mathrm{Em}$ grande medida, isso reflete o reforço da importância do Atlântico Sul como espaço geopolítico prioritário para o Brasil, bem como uma vinculação crescente entre as políticas externa e de defesa do País, processo que teve seu início ainda no governo Lula - com a criação da Estratégia Nacional de Defesa, em 2008, por exemplo -, intensificando-se durante o governo Rousseff - com a publicação do Livro Branco de Defesa Nacional, em 2012, por exemplo (ABDENUR; NETO, 2014). Ainda nesse contexto, cabe ressaltar que o ex-chanceler Celso Amorim, que atuou como Ministro da Defesa ao longo do primeiro mandato de Dilma Rousseff, realizou visitas oficiais a seis países africanos entre 2011 e 2014 (visitando alguns deles

\footnotetext{
13 Apenas 5 projetos na área de Defesa, dos 481 estabelecidos (BRASIL, 2015a).

${ }^{14}$ Com 25 dos 156 projetos de cooperação sendo na área de Defesa (BRASIL, 2015a).
} 


\section{Conjuntura Austral}

mais de uma vez ${ }^{15}$ enquanto esteve à frente da pasta, reforçando, assim, a ideia de que a área de Defesa recebeu uma atenção prioritária na política africana de Dilma.

\section{Conclusão}

Frente ao que foi exposto, podemos afirmar que a política externa brasileira para a África passou apenas por uma mudança de ajuste, a partir da perspectiva estabelecida por Hermann (1990), entre os governos Lula e Rousseff. Assim, houve apenas a diminuição da intensidade das relações do Brasil com o continente (expressa no menor número de visitas da presidenta e de projetos de cooperação estabelecidos), sem entretanto alterar o seu espaço na política externa brasileira. Nesse sentido, a África continua sendo vista pelo governo brasileiro como um espaço fundamental para elevar o perfil internacional do Brasil, além de proporcionar acesso a novos mercados e oportunidades econômicas e maior influência em foros multilaterais.

Em grande medida, a mudança de ajuste realizada pelo governo Rousseff poderia ser associada à ideia defendida por Putnam (2010), que argumenta que a política interna e a política externa afetam-se mutuamente. Nesse sentido, o autor destaca que a definição da política externa não depende de um ator unitário, sendo uma composição dos interesses do nível nacional (em que grupos setoriais pressionam o governo) e do nível internacional (em que se busca satisfazer as pressões internas e, ao mesmo tempo, minimizar as consequências internas de situações adversas no plano exterior).

Nesse contexto, os choques externos, evidenciados pelo cenário internacional mais desfavorável (com a intensificação dos impactos da crise econômica mundial e com uma renovada atuação das potências ocidentais no continente africano), e também um cenário interno mais conturbado (alguns sinais de esgotamento do modelo interno de crescimento, a necessidade de renovar a infraestrutura nacional e as manifestações populares ocorridas em 2013, entre outros), teriam servido como fontes para que o governo Rousseff realizasse uma mudança na intensidade com que o país busca sua inserção no continente africano. Além disso, as diferenças nos perfis políticos de Lula e Dilma também poderiam ser apontados como fatores para a mudança - ainda que não

\footnotetext{
15 Amorim realizou visitas a Cabo Verde, em 2011; a Angola, Namíbia e Cabo Verde, em 2013; e a Moçambique, África do Sul, República Democrática do Congo e Angola em 2014 (BRASIL, 2015b).
} 


\section{Conjuntura Austral}

tenham se mostrado como determinantes. Apesar dessa mudança, entretanto, fica claro que os objetivos da política externa brasileira para o continente africano se mantiveram os mesmos nos dois governos (devendo se manter assim também no próximo mandato de Dilma Rousseff), o que é evidenciado pela manutenção dos laços e da realização de projetos de cooperação com o continente - com particular ênfase à cooperação em matéria de Defesa -, em menor escala, mas com profundidade e concepções semelhantes às definidas pelo governo anterior.

\section{REFERÊNCIAS}

ABDENUR, Adriana E.; NETO, Danilo M. O Atlântico Sul e a cooperação em Defesa entre o Brasil e a África. In: NASSER, Reginaldo M.; MORAES, Rodrigo F (Orgs.). O Brasil e a segurança no seu entorno estratégico: América do Sul e Atlântico Sul. Brasília: IPEA, 2014.

ALVES, Ana Cristina. Brazil-Africa Technical Co-operation: Structure, Achievements and Challenges Policy Briefing 69. Global Powers and Africa Programme. Johannesburg: South African Institute of International Affairs, 2013, 4p.

AMORIM, Celso. Brazilian Foreign Policy under Lula. Revista Brasileira de Política Internacional, v.53, Edição Especial, p. 214-240, 2010.

BACHEGA, Hugo. Patriota nega recuo de política externa e diz que 'era hora de consolidar'. BBC Brasil. São Paulo, 22 maio 2014. Disponível em: $<$ http://www.bbc.co.uk/portuguese/noticias/2014/05/140513_entrevista_patriot a_hb>. Acesso em 12 abr. 2015.

BANCO MUNDIAL; Instituto de Pesquisas Econômicas Aplicadas (IPEA). Ponte sobre o Atlântico: Brasil e África Subsaariana, parceria Sul-Sul para o crescimento. Brasília, 2011. 135 p.

BERTAZZO, Juliana. An Initial Survey of the Dilma Rousseff Administration in Brazil. Critical Sociology, v.38, n.6, p.889-892, 2012.

BNDES inaugura escritório de representação na África. Banco Nacional de Desenvolvimento Econômico e Social (BNDES). Rio de Janeiro, 06 dez. 2013.

$<$ http://www.bndes.gov.br/SiteBNDES/bndes/bndes_pt/Institucional/Sala_de_I 


\section{Conjuntura Austral}

mprensa/Noticias/2013/Todas/20131206_africa.html>. Acesso em 11 nov. 2014.

BRASIL, Agência Brasileira de Cooperação (ABC). Projetos - Cooperação Sul-Sul. 2015a. Disponível em: <www.abc.gov.br/projetos>. Acesso em 12 abr. 2015.

BRASIL, Angola e FAO assinam acordo de cooperação. Empresa Brasileira de Agropecuária (Embrapa). Brasília, 22 jan. 2014. Disponível em: $<$ https://www.embrapa.br/busca-de-noticias/-/noticia/1577373/brasil-angola-efao-assinam-acordo-de-cooperacao>. Acesso em 11 nov. 2014.

BRASIL, Ministério da Defesa. Agenda do Ministro. 2015b. Disponível em: $<$ http://www.defesa.gov.br/index.php/agenda-de-autoridades/agenda-doministro $>$. Acesso em 10/04/2015.

BRASIL, Ministério das Relações Exteriores. Balanço de Política Externa 2003-2010 - Resumo Executivo. 2011a. Disponível em $<$ http://www.itamaraty.gov.br/temas/balanco-de-politica-externa-20032010/resumo-executivo/>. Acesso em: 04 nov. 2013.

BRASIL, Ministério das Relações Exteriores. Balanço de Política Externa 2003-2010 - África - Defesa. 2011b. Disponível em $<$ http://www.itamaraty.gov.br/temas/balanco-de-politica-externa-20032010/2.2.14-africa-defesa/at_download/file>. Acesso em: 04 nov. 2013.

BRASIL, Ministério das Relações Exteriores. Balanço de Política Externa 2003-2010 - África - Saúde. 2011c. Disponível em $<$ http://www.itamaraty.gov.br/temas/balanco-de-politica-externa-20032010/2.2.4-africa-saude/view>. Acesso em: 04 nov. 2013.

BRASIL, Ministério das Relações Exteriores. Visitas internacionais do Presidente Lula e visitas ao Brasil de Chefes de Estado e de Chefes de Governo: 20032010. 2011d. Disponível em: <http://www.itamaraty.gov.br/temas/balanco-depolitica-externa-2003-2010/visitas-internacionais-do-presidente-lula-e-visitasao-brasil-de-chefes-de-estado-e-de-chefes-de-governo-2003-a-2010>. Acesso em: 04 nov. 2013.

CABRAL, Lídia. Cooperação Brasil-África para o desenvolvimento: Caracterização, tendências e desafios. Textos Cindes N²6. Rio de Janeiro: Centro de Estudos de Integração e Desenvolvimento (CINDES), 2011, 39p.

DAUVERGNE, Peter; FARIAS, Déborah. The Rise of Brazil as a Global Development Power. Third World Quarterly, London, v. 33, n. 5, p. 903-917, 2012. 


\section{Conjuntura Austral}

GARCIA, Marco A.. Dez anos de Política Externa. In: SADER, Emir (Org.). Lula e Dilma: 10 anos de governos pós-neoliberais no Brasil. São Paulo: Boitempo; Rio de Janeiro: FLACSO Brasil, 2013.

HERMANN, Charles F. Changing Course: When Governments Choose to Redirect Foreign Policy. International Studies Quarterly, $n^{0} 34$. International Studies Association, 1990, p. 3-21.

LECHINI, Gladys. O Brasil na África ou a África no Brasil? A construção da política africana pelo Itamaraty. Nueva Sociedad, México, No35, Jul-Dez 2008, pp.5571. Disponível em: <http://www.nuso.org/upload/articulos/p9-4_1.pdf > Acesso em 12 maio 2012.

MARULL, Yana. Brasil confirma prioridade da África em sua política externa ao perdoar dívidas. Yahoo Notícias. [S.1], maio, 2013 Disponível em: $<$ br.noticias.yahoo.com/brasil-confirma-prioridade-áfrica-política-externa-aoperdoar-194047683.html>. Acesso em: 24 nov. 2013.

MIYAMOTO, Shiguenoli. A política externa brasileira para a África no início do novo século: interesses e motivações. XI Congresso Luso Afro Brasileiro de Ciências Sociais. Salvador, 2011.

NETO, Danilo M. S. Brazil \& Africa: Challenges and opportunities. Africa Quarterly. New Delhi, v.51, n.3-4, Special Edition, p.76-85, 2012.

PENHA, Eli Alves. Relações Brasil-África e a Geopolítica do Atlântico Sul. Salvador: EDUFBA, 2011.

PEREIRA, Anthony W. Continuity Is Not Lack of Change. Critical Sociology, v.38, n.6, p.777-787, 2012.

PINHO, Carlos E. S. Cooperación Sur-Sur para el Desarrollo: Las Relaciones BrasilÁfrica en la Promoción de las Políticas Públicas (2003-2012). América Latina Hoy, Salamanca, n.63, p. 91-112, 2013.

PUTNAM, Robert D. Diplomacia e política doméstica: a lógica do jogo de dois níveis. Revista de Sociologia e Política, Curitiba, v.18, n.36, p.147-174, 2010.

RIZZI, Kamilla R.; MAGLIA, Cristiana; PAES, Lucas; KANTER, Marcelo. O Brasil na África (2003-2010): Política, Desenvolvimento e Comércio. Conjuntura Austral, v.2, n.5. 2011. P. 1-21.

SARAIVA, Flavio, África parceria do Brasil atlântico: Relações Internacionais do Brasil e da África no início do século XXI. Belo Horizonte: Fino Traço, 2012. 


\section{Conjuntura Austral}

SENNES, Ricardo. As mudanças da política externa brasileira nos anos 80: uma potência média recém industrializada. Porto Alegre: Editora da UFRGS, 2003.

SILVA, André Luiz R. As transformações matriciais da Política Externa Brasileira recente (2000-2010). Meridiano 47, Brasília, v.11, n.120, p.18-24, 2010.

SILVA, Luiz Inácio (Lula) da. Pronunciamento do Presidente da República, Luiz Inácio Lula da Silva, na sessão solene de posse no Congresso Nacional, Brasília - DF, 01 de janeiro de 2013. Disponível em : $<$ http://www.biblioteca.presidencia.gov.br/ex-presidentes/luiz-inacio-lula-dasilva/discursos-de-posse/discurso-de-posse-1o-mandato/at_download/file>. Acesso em: 10 de dezembro de 2014.

SILVEIRA, Virgínia. EMBRAER fecha venda de Super Tucano para três países da África. Valor Econômico. São Paulo, 28 mar. 2012. Disponível em: $<$ http://www.valor.com.br/empresas/2591312/embraer-fecha-venda-de-supertucano-para-tres-paises-da-africa>. Acesso em 11 nov. 2014.

STOLTE, Christina. Brazil in Africa: Just Another BRICS Country Seeking Resources? Chantham House Briefing Paper - November 2012. Africa Programme and Americas Programme. London: Chantham House, 2012, 20 p.

TEIXEIRA, Rodrigo A.; PINTO, Eduardo C. A economia política dos governos FHC, Lula e Dilma: dominância financeira, bloco no poder e desenvolvimento econômico. Textos para Discussão 006 - 2012. Rio de Janeiro: Universidade Federal do Rio de Janeiro - Instituto de Economia, 2012, 35p. Disponível em: $<$ http://www.ie.ufrj.br/images/pesquisa/publicacoes/discussao/2012/IE_Teixeir a_Pinto_2012_TD006.pdf $>$. Acesso em: 24 nov. 2013.

VILLELA, Flávia. Feira de defesa e segurança vai trazer bons acordos para o Brasil, diz Amorim. Agência Brasil. Brasília, 08 abr. 2013. Disponível em $<$ http://ebc.com.br/noticias/brasil/2013/04/feira-de-defesa-e-seguranca-vaitrazer-bons-acordos-para-o-brasil-diz-amorim>. Acesso em 11 nov. 2014.

VISENTINI, Paulo G.F. Prestige Diplomacy, Southern Solidarity or Soft Imperialism? Lula's Brazil-Africa Relations (2003 onwards). [2009] Preliminary version. Seminar: Leiden, 2009. Presented on Research Seminars at African Studies Centre, April, 16, 2009. Disponível em: $<$ http://www.ascleiden.nl/GetPage.aspx?url=/events/event1239091101>. Acesso em 8 nov. 2013.

Recebido em 20 novembro de 2014. Aprovado em 23 de abril de 2015. 


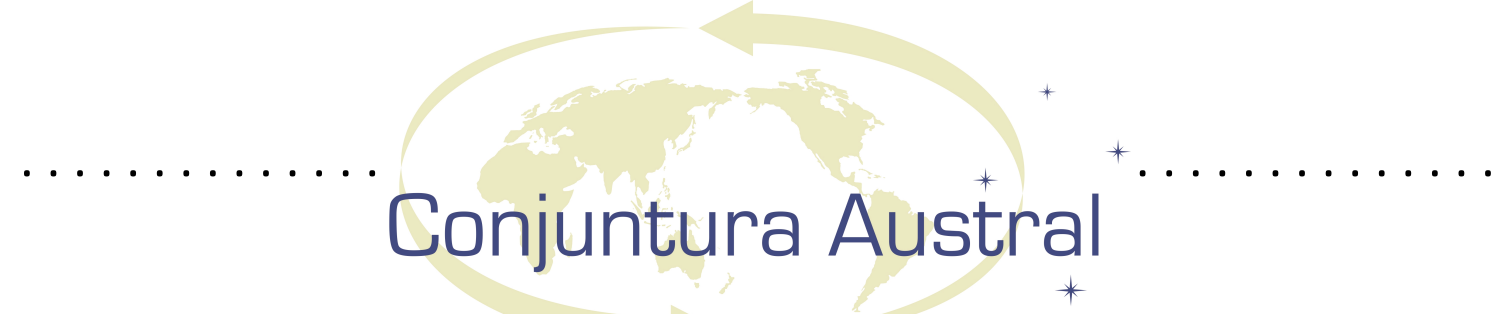

\title{
RESUMO
}

A política externa brasileira para a África sofreu uma importante inflexão a partir de 2003. Depois de um longo período de distanciamento, a ascensão ao poder de Luiz Inácio (Lula) da Silva marcou uma reorientação clara da política externa brasileira, e uma retomada da atribuição de importância ao continente africano. Ao longo dos dois mandatos de Lula, o Brasil se reaproximou da África, ampliando sua participação no continente e transformando-o em um importante parceiro do país, não só em termos políticos, mas também econômicos. Em 2011, Dilma Rousseff assumiu a presidência do Brasil, e o ministro das Relações Exteriores, Celso Amorim, foi substituído por Antônio Patriota, levantando muitos questionamentos acerca dos rumos que seriam adotados na condução da política externa do novo governo. Este trabalho busca analisar se houve, ou não, uma mudança na política externa brasileira para a África no governo Dilma Rousseff em relação ao governo Lula da Silva e, em caso positivo, qual a sua profundidade. Para tanto, apoia-se nos trabalhos de Charles Hermann (1990), para analisar os diferentes níveis de mudança de política externa; Ricardo Sennes (2003), para demonstrar que há uma continuidade na matriz de política externa dos governos Lula e Dilma; e de Robert Putnam (2010), para demonstrar que as mudanças ocorridas, em grande medida, são reflexos das transformações ocorridas tanto no cenário internacional quanto no cenário interno do país.

Palavras-chave: Política Externa Brasileira; África; Dilma Rousseff; Lula; Mudança;

\begin{abstract}
Brazilian foreign policy towards Africa has suffered a major inflection from 2003. After a long period of estrangement, the rise to power of Luiz Inácio (Lula) da Silva underscored a clear reorientation of Brazilian foreign policy, and a resumption of the assignment of importance to the African continent. Over the two terms of Lula, Brazil has reconnected Africa, increasing its participation in the continent and making it an important partner, not only politically, but also economically. In 2011, Rousseff became president of Brazil, and Celso Amorim, then foreign minister, was replaced by Antonio Patriota, raising many questions about the directions that would be adopted in the new government's conduct of foreign policy. This paper seeks to analyze whether there has or has not been a shift in Brazil's foreign policy towards Africa in the Rousseff administration in relation to the Lula da Silva government and, if so, how deep has it been. To do so, it relies on the work of Charles Hermann (1990), to analyze the different levels of change in foreign policy; Ricardo Sennes (2003), to demonstrate that there is a continuity in the foreign policy matrix between Lula and Dilma; and Robert Putnam (2010), to demonstrate that the changes that have occurred are, to a large extent, a reflection of the transformations that have taken place in both the international scenario and the domestic arena.
\end{abstract}

Keywords: Brazilian Foreign Policy; Africa; Dilma Rousseff; Lula; Change; 


\title{
Conjuntura Austral
}

\section{TOCADA PELA PRIMEIRA VEZ? DEFESA COLETIVA, GESTÃO DE CRISES E SEGURANÇA COOPERATIVA NO NOVO CONCEITO ESTRATÉGICO DA OTAN}

\section{Touched for the very first time? Collective defense, crisis management and cooperative security in the new NATO Strategic Concept}

\author{
Diego Santos Vieira de Jesus ${ }^{1}$
}

No contexto de sua criação em 1949, a Organização do Tratado do Atlântico Norte (OTAN) agregou Estados que tinham interesses convergentes no que dizia respeito à organização da defesa comum do espaço norte-atlântico. Naquele momento, o objetivo era fazer frente à ameaça representada pela URSS, salvaguardando a liberdade e a segurança de todos os seus membros por meios políticos e militares (RIBEIRO, 2011, p.1). Mais de duas décadas após o fim da Guerra Fria, a organização chega a um momento da sua história em que se vê obrigada a lidar com desenvolvimentos ainda mais complexos. As dificuldades em teatros de operações como o Afeganistão deixam claro que as operações militares não permitirão por elas mesmas atingir um resultado satisfatório. Além disso, a proliferação de ameaças assimétricas e não-tradicionais amplia a possibilidade de conflito nas fronteiras aliadas. A crise econômico-financeira iniciada em 2008 nos EUA aponta para a necessidade de racionalização de estruturas e recursos (LEMOS \& EUGÉNIO, 2011, p.56). Em 2014, durante uma conferência no Reino Unido, os membros da OTAN manifestaram seu apoio à Ucrânia nos conflitos com separatistas pró-Rússia, ainda que tenham excluído a possibilidade de uma intervenção militar e um possível ingresso da Ucrânia na aliança militar. O governo russo negou envolvimento direto na crise, mas os líderes da aliança atribuíram à Rússia uma influência desestabilizadora na região, solicitando a ela que retirasse suas tropas da

\footnotetext{
${ }^{1}$ Doutor em Relações Internacionais e Professor da Graduação em Relações Internacionais da Escola Superior de Propaganda e Marketing do Rio de Janeiro (ESPM-Rio) e do Centro Universitário Hermínio da Silveira IBMR - Laureate (UNI-IBMR) (dvieira@espm.br; diego.jesus@ibmr.br).
} 


\section{Conjuntura Austral}

Ucrânia, interrompesse o fluxo de armas, soldados e fundos aos separatistas e colocasse fim à anexação da Crimeia. Ademais, o avanço do grupo terrorista Estado Islâmico no norte do Iraque também esteve na pauta da cúpula.

A definição das linhas essenciais da estratégia da OTAN deve levar em consideração ameaças cada vez mais complexas e multifacetadas num mundo globalizado. O ambiente internacional dos próximos anos incorpora aspectos como a maior assertividade da Rússia; o fortalecimento de potências de dimensão continental, como China, Índia e Brasil, bem como Estados menores, mas de grande potencial de crescimento; dificuldades financeiras nas economias desenvolvidas e maior desenvolvimento das emergentes; e o maior número de regiões desestruturadas e sem controle, onde se desenvolvem conflitos étnico-religiosos. Colocam-se, assim, questões importantes para a OTAN, como as formas de fazer frente à natureza das ameaças previsíveis, ultrapassar o dilema segurança regional/segurança global, vencer as dificuldades de atuar fora da região e manter a coesão interna. Embora haja o lastro de segurança que apenas o vetor militar pode oferecer, são muitas vezes indispensáveis ao sucesso da organização a contribuição da diplomacia; as medidas de apoio econômico e social; as atividades de assistência e de governança; a execução de tarefas logísticas e a cooperação em termos de treinamento. Ainda que poderosos, os recursos da OTAN nem sempre bastam para a realização de respostas eficazes, seja por insuficiência estrutural ou conjuntural de meios ou pela necessidade de utilização de certos espaços e vias de acesso que a organização não controla. Tais respostas também podem tomar muito tempo e exigir empenho global. Torna-se necessário, nesse sentido, recorrer cada vez mais a medidas de segurança em cooperação com outros Estados e organizações para que o êxito possa ser atingido (SANTOS, 2010, p.39-40).

A fim de lidar com tantos desafios, a OTAN conta com as orientações estabelecidas nos seus Conceitos Estratégicos. A elaboração desses documentos - que não são juridicamente vinculantes nem trazem informações objetivas de natureza financeira - reflete a busca de construção de consenso entre os membros da organização acerca de ameaças existentes e potenciais, a codificação de práticas desenvolvidas e a estipulação de formas de ação diplomática e militar em relação a Estados não-membros. Eles definem, assim, os grandes princípios políticos comuns para enquadrar as decisões 


\section{Conjuntura Austral}

e ações da OTAN e são evolutivos em vez de revolucionários: um novo Conceito Estratégico traz inovações, mas não rompe completamente com os anteriores, uma vez que possuem semelhanças evidentes (RIBEIRO, 2011, p.12). O sétimo e último Conceito Estratégico da OTAN foi aprovado na reunião de Lisboa em 2010, apontando para o enfrentamento de um conjunto de novas ameaças mais complexas. Quatro documentos de circulação interna e restrita foram produzidos na Guerra Fria com o objetivo de orientar o planejamento militar em relação à ameaça representada pela URSS, ao passo que os outros três produzidos após o fim da ordem bipolar foram mais abrangentes e amplamente discutidos, sinalizando ameaças e riscos à segurança dos membros da organização. A adoção de um novo Conceito Estratégico em 2010 foi um avanço, uma vez que prometia colocar fim a um período traumático na história da organização, no qual fora dominada por uma crise em que seu papel não estava claro, as relações entre seus membros estavam abaladas, e o sucesso no engajamento no Afeganistão mostrava-se difícil. O novo Conceito Estratégico pretendia oferecer à organização uma "curva de Madonna", expressão utilizada por van Ham (2008) ao analisar a OTAN, em referência à artista pop por sua capacidade de adaptação a novas tarefas e de reinvenção em face de possíveis quedas, enquanto preservava seus princípios básicos e mantinha a determinação para conquistar cada vez mais relevância.

O novo Conceito Estratégico definia a OTAN como uma aliança modernizada e um jogador cooperativo num mundo globalizado. Essa mudança se fazia necessária porque, embora a OTAN estivesse atualmente mais ativa do que em qualquer outro momento da sua história, seus propósitos e valores estavam menos claros do que no passado, e o sucesso era mais dificilmente conquistado (FLOCKHART, 2011, p.5-9). Uma das novidades do Conceito Estratégico de 2010 foi a importância dada ao processo de produção do documento. As reflexões, as consultas e os rascunhos do Conceito Estratégico eram percebidos como oportunidades para se construir entendimento e se engajarem vários atores para comprometer os aliados a um conjunto renovado de princípios, papeis e políticas. O debate foi ampliado para trazer a contribuição do público e de especialistas. Definiu-se inclusive um grupo de peritos que estavam no centro da reflexão e que produziram um relatório que orientou o debate (OTAN, 2014). 


\section{Conjuntura Austral}

O objetivo do artigo é explicar por que a OTAN adotou um novo Conceito Estratégico em 2010. O argumento central indica que a adoção de tal Conceito Estratégico está relacionada à necessidade de aprimoramento da defesa coletiva para se garantir o conjunto de capacidades necessárias ao enfrentamento das novas ameaças e ao fortalecimento das capacidades da organização para a gestão de crises e a segurança cooperativa, o que implicava o incremento da troca de informações, a melhoria das capacidades militares, o desenvolvimento de capacidades de natureza civil, a ampliação e a intensificação das consultas políticas entre os membros da OTAN e a maior cooperação com Estados não-membros da organização e outras instituições internacionais. Além de propor a ampliação de capacidades para as ações funcionais, o novo Conceito Estratégico também ressalta a importância do uso contínuo da ação retórica para a reafirmação dos valores compartilhados e da coesão da organização. Para que se entendam as continuidades e mudanças com a adoção do último Conceito Estratégico da organização, examinarei primeiramente os traços de continuidade e mudança nos Conceitos Estratégicos adotados durante a Guerra Fria e na década de 1990 nas duas próximas seções. A seguir, analisarei os principais pontos do novo Conceito Estratégico. Antes de tecer as considerações finais, examinarei nas duas seções seguintes as continuidades e mudanças no novo Conceito Estratégico em relação aos anteriores e seus principais avanços e limitações, respectivamente.

\section{Os Conceitos Estratégicos da OTAN durante a Guerra Fria}

A formulação da decisão na OTAN sempre foi um processo permeado por problemas, porque ele inevitavelmente carrega o potencial para que se evidencie a falta de unidade na organização e se exponham assim as tensões estruturais e as contradições inerentes da Aliança. Como uma organização intergovernamental sem transferência de soberania para suas estruturas institucionais, a OTAN tem um processo de formulação de decisões baseadas em consenso. Se por um lado a unidade nessas decisões sempre foi vista como uma prova da coesão entre seus membros, a falta de unidade foi vista como um desafio à determinação da OTAN na garantia da defesa coletiva. Em alguns momentos durante a Guerra Fria, tinha-se a sensação de que o medo dos aliados europeus quanto à divergência em relação aos EUA era maior do que aquele que tinham 


\section{Conjuntura Austral}

em relação a um ataque pela URSS. As decisões da OTAN pareciam estar relacionadas à coesão e à credibilidade da dissuasão estendida, o que levara à constante reafirmação retórica de valores compartilhados da Aliança e um medo latente de ruptura da unidade. Por conta disso, a busca do consenso para algumas decisões conduziu a negociações e tentativas de persuasão cuidadosas, tendo os EUA um papel de líder firme e paciente. Nos primeiros quarenta anos da organização, nenhuma missão militar foi conduzida, e a ação funcional ficou confinada a exercícios militares, planejamento estratégico e formulação de decisão sobre procedimentos (FLOCKHART, 2011, p.32-33).

As divergências sobre a própria natureza da OTAN evidenciam as divisões entre seus membros. Nos primeiros anos da organização, os EUA desejavam evitar compromissos permanentes como a defesa das democracias europeias, o que fica nítido na ambiguidade dos termos do Tratado de Washington: a cláusula relacionada à defesa coletiva só obriga os aliados a responderem a uma agressão armada da forma considerada necessária com o objetivo de preservar a autonomia dos EUA para decidirem o momento e a intensidade da reação a um ataque contra a OTAN. Os EUA não poderiam, entretanto, deixar de responder a uma invasão de seus aliados europeus sem perder a credibilidade no nível externo. Ao mesmo tempo, aliados europeus como França e Reino Unido questionaram com relativa frequência a validade da garantia de segurança dos EUA, em especial após o desenvolvimento de uma capacidade nuclear significativa pela URSS (GASPAR, 2010, p.12-13).

A tentativa de construção de unidade fica clara nos primeiros Conceitos Estratégicos da OTAN. Os Conceitos Estratégicos da época da Guerra Fria eram mais simples e privilegiavam tarefas como a dissuasão e a defesa em relação ao Pacto de Varsóvia, as quais se traduziram na presença avançada de forças aliadas junto às fronteiras de Estados europeus pertencentes ao bloco comunista e na concepção de "resposta flexível”, viabilizada pela presença de armas nucleares estratégicas e nãoestratégicas, bem como de sistemas convencionais. O fim da Guerra Fria trouxe à OTAN o questionamento acerca de sua relevância em face do desaparecimento da ameaça que constituíra a razão de ser da organização. Entretanto, tanto na América do Norte como na Europa identificava-se a defesa de continuação da OTAN por conta das incertezas em torno de ameaças externas ao espaço norte-atlântico; da capacidade de 


\section{Conjuntura Austral}

adaptação revelada pela organização para prevenir, conter e controlar conflitos militares nas Europas Central e Oriental; e do papel da organização na cooperação entre os membros europeus e os norte-americanos (RIBEIRO, 2011, p.1-2).

O primeiro Conceito de 1950 afirmava que a principal função da OTAN era a dissuasão, e, caso tal função não fosse alcançada, as forças dos membros da Aliança seriam envolvidas em combate no caso de um ataque da URSS. Tais membros buscavam complementaridade e padronização e reconheciam a inferioridade numérica no que dizia respeito a armamento convencional, o que apontava gradativamente para uma maior dependência em relação à capacidade nuclear dos EUA e a necessidade da OTAN de assegurar a capacidade de conduzir um bombardeio estratégico imediato por todos os meios possíveis e com todas as armas, sem exceção. Com o início da Guerra da Coreia em 1950, a eficácia das estruturas militares aliadas foi colocada em dúvida, levando a uma reformulação do primeiro Conceito. Teve-se a criação da estrutura militar integrada a partir da década de 1950, e, com a inauguração de novos órgãos na instituição e a integração da Grécia e da Turquia, o segundo Conceito - datado de 1952 - ajustava a estratégia anterior com a manutenção de princípios fundamentais (LEMOS \& EUGÉNIO, 2011, p.56-57). Entretanto, em 1952, a OTAN definiu objetivos muito ambiciosos que se mostraram financeira e politicamente impraticáveis. Os EUA decidiram mudar a ênfase de sua política de defesa para uma maior dependência em relação ao uso de armas nucleares, o que oferecia maior efetividade militar sem se ter que gastar muito em defesa. Embora se fizessem alusões às armas nucleares em documentos estratégicos, tais armas não tinham sido ainda plenamente integradas a uma estratégia da OTAN. Os EUA e alguns membros europeus gradativamente clamavam pela integração completa da política sobre armas nucleares numa estratégia da organização (OTAN, 2014).

O terceiro Conceito, que data de 1957, centrava a estratégia no uso das armas nucleares, o que permitia reduzir os requisitos de forças convencionais e os encargos com a defesa de membros da aliança. Não houve consenso entre os aliados, de forma que foi introduzida uma cláusula que permitia que, diante de agressões menores, não haveria a obrigação de se recorrer necessariamente a armas nucleares, nem se aceitava a ideia de uma guerra limitada com a URSS. O conceito de retaliação em massa e as 


\section{Conjuntura Austral}

preocupações com as atividades soviéticas fora da região norte-atlântica - como na Crise de Suez em 1956 - foram incorporados ao Conceito, além da maior preocupação com assuntos não-militares, como as consultas entre os Estados membros acerca das relações entre os blocos capitalista e comunista. Em 1956, Canadá, Itália e Noruega recomendaram a solução pacífica de controvérsias entre os membros, uma vez que a Crise de Suez provocou divisões na aliança, bem como a cooperação nas áreas econômica, técnica, científica e cultural. A dependência em relação às armas nucleares dos EUA para a defesa europeia fez com que Estados europeus temessem que os EUA não se empenhassem totalmente caso houvesse um ataque soviético circunscrito ao continente europeu. Após a segunda crise de Berlim (1958-1962) e a crise dos mísseis em Cuba (1962), ficara claro que a possibilidade de retaliação em massa não impedira as ameaças da URSS, de forma que até os EUA iniciaram a defesa de uma estratégia de "resposta flexível" aos avanços soviéticos. O quarto e último Conceito Estratégico da OTAN durante a Guerra Fria foi aprovado em 1968 - após o início da Guerra do Vietnã e a retirada das forças francesas da estrutura integrada da organização - e advogava a flexibilidade e a escalada. A flexibilidade evitaria que agressores potenciais soubessem com certeza a resposta específica da OTAN, concluindo que enfrentariam um grau de risco extremamente elevado e inaceitável, independentemente da natureza do seu ataque. Dentre as respostas militares à agressão, estavam a defesa direta, usando o mesmo nível da agressão; a escalada deliberada, prevendo a ameaça de uso das armas nucleares, à medida que a crise progredisse; e a resposta nuclear geral, entendida como o último degrau de dissuasão (LEMOS \& EUGÉNIO, 2011, p.59-60).

Fica claro que as crises relacionadas às decisões acerca das armas nucleares começaram com a adoção do Conceito Estratégico de 1957, seguidas por difíceis negociações que levaram à adoção do Conceito Estratégico seguinte, com a incorporação do conceito de "resposta flexível". As negociações que conduziram a esses dois Conceitos Estratégicos foram associadas a crises na formulação da decisão, além de que o acordo em torno de uma "resposta flexível" só foi possível por conta da retirada da França da estrutura militar integrada da OTAN em 1966. Ambos os Conceitos Estratégicos eram baseados no princípio de dissuasão estendida e incluíam uma confiança pesada nas armas nucleares, o que periodicamente fazia com que a 


\section{Conjuntura Austral}

OTAN tomasse decisões relacionadas a desdobramentos de armas nucleares a fim de garantir a ligação entre as partes europeias e norte-americanas da Aliança. É interessante observar que a ação funcional trazia o potencial latente para crises e a ameaça à coesão entre os aliados, enquanto a ação retórica era reconhecida como um método mais provável de garantir tal coesão, em particular por meio da afirmação dos valores compartilhados e das garantias dos EUA acerca da credibilidade da dissuasão estendida. A ação retórica quanto à "resposta flexível" é emblemática nesse sentido, especialmente no uso da ambiguidade. Em tal resposta, a ambiguidade era elevada a seu potencial máximo, permitindo a cada lado do Atlântico acreditar que sua interpretação do papel das armas nucleares na estratégia da OTAN tinha prevalecido. Todos os aliados concordavam implicitamente em não desafiar tal ambiguidade, e, como resultado, a OTAN desenvolveu uma prática de negociações cuidadosas sem desafiar a ambiguidade essencial, bem como a relutância a se engajar em decisões que levassem a mudanças muito substantivas por meio da ação funcional (FLOCKHART, 2011, p.33).

Conforme a OTAN definia seus objetivos estratégicos para os vinte anos seguintes, ela decidiu elaborar um relatório que oferecia uma perspectiva para segurança em dois caminhos: o político e o militar. O relatório Harmel de 1967 ofereceu uma análise abrangente do ambiente de segurança desde a assinatura do Tratado do Atlântico Norte em 1949 e defendia a necessidade de se manter uma defesa adequada enquanto se buscasse o relaxamento das tensões nas relações entre Leste e Oeste e se trabalhasse por soluções para os problemas políticos que dividiam a Europa. Em termos políticos, a tarefa seria a formulação de propostas para reduções de forças no Leste e no Oeste; em termos militares, o foco era a defesa de áreas expostas, especialmente o Mediterrâneo. O relatório, elaborado durante a détente entre EUA e URSS, definiu o tom dos primeiros passos da OTAN na direção de uma perspectiva mais cooperativa para as questões de segurança que surgiriam em 1991; entretanto, entre 1967 e 1991, ainda houve momentos de tensão entre os blocos. As tensões aumentaram com a invasão soviética do Afeganistão e o desdobramento de mísseis soviéticos SS-20. Em 1979, a OTAN ofereceu ao Pacto de Varsóvia uma limitação mútua de mísseis balísticos de alcance médio e intermediário, mas, sem uma reação positiva da URSS, ameaçou desdobrar os mísseis Pershing e mísseis de cruzeiro, o que acabou realmente fazendo. A détente 


\section{Conjuntura Austral}

desenvolveu-se com a negociação e a assinatura de acordos entre EUA e URSS para a limitação e a redução de armas nucleares. Na segunda metade da década de 1980, ambos os blocos apontavam para a construção de confiança, mas a desconfiança mútua ainda caracterizava as relações Leste-Oeste. Somente após a queda do Muro de Berlim, a dissolução do Pacto de Varsóvia e o fim da URSS as relações poderiam começar numa nova base (OTAN, 2014; SHEA, 2010, p.13-14).

\section{Os Conceitos Estratégicos da OTAN na década de 1990}

O fim da Guerra Fria abriu espaço para a formação de uma crescente autonomia dos Estados europeus na esfera de defesa. Entretanto, a incerteza no processo de transição da Rússia após o fim da URSS exigia a continuidade da garantia estratégica norte-americana. Ademais, os acordos da unificação alemã estipulavam a continuidade de seu status de potência não-nuclearmente armada e previam que ela continuaria a ser membro da OTAN com o objetivo de não buscar meios para garantir autonomamente a sua segurança. A OTAN também se mostrava relevante para a manutenção do vínculo transatlântico entre os EUA e os Estados europeus, que tinha assegurado a paz desde o fim da II Guerra Mundial, ainda que a organização pudesse se tornar supérflua, com o desaparecimento do inimigo principal. A Rússia após o fim da URSS não tinha deixado de ser uma ameaça, a necessidade de contenção da Alemanha não tinha sido eliminada, e a garantia norte-americana da paz na Europa não tinha se tornado irrelevante. Além da garantia de suas funções cruciais, a OTAN deveria incluir também a intervenção militar dos aliados em crises "fora da área" do Tratado de Washington em missões expedicionárias (GASPAR, 2010, p.14-16).

Em face da maior abertura no contexto de fim gradual da Guerra Fria, tornou-se público pela primeira vez um Conceito Estratégico da organização: o quinto Conceito, datado de 1991, rompeu com os anteriores na medida em que não identificou claramente um inimigo e abriu as portas da OTAN a todo o espaço pós-soviético por meio de parcerias e diálogos. Ainda que preservasse a defesa coletiva como o núcleo da estratégia da organização, o Conceito reduzia o papel das forças nucleares para níveis suficientes à garantia da paz e da estabilidade. As ações de combate nos Bálcãs na década de 1990 - enquadradas pelo novo Conceito Estratégico - sinalizavam uma 


\section{Conjuntura Austral}

vocação da OTAN para a solução eficaz de conflitos, o que atribuiu à organização uma nova vida em face dos questionamentos sobre sua falta de utilidade diante da ausência de um inimigo claro identificado (LEMOS \& EUGÉNIO, 2011, p.60-61). Para que se desempenhassem as tarefas de segurança, consulta, dissuasão, defesa e a manutenção do equilíbrio estratégico na Europa, tal Conceito Estratégico trouxe como linhas de ação prioritárias a manutenção da segurança dos membros; a cooperação com antigos rivais; a abordagem à segurança com base na cooperação e no diálogo; a redução da dependência em relação às armas nucleares; e a ampliação da flexibilidade e da mobilidade das forças aliadas. Fica evidente que as preocupações estratégicas da organização eram a manutenção da segurança na Europa num contexto de incertezas políticas e a permanência do equilíbrio estratégico na relação com a Rússia, que ainda mantinha um poder militar relevante. Novas estruturas de forças e de comandos foram estabelecidas, e foi conferida maior relevância às forças convencionais. $\mathrm{O}$ caráter conjunto das forças foi fortalecido em face das lições extraídas da Guerra do Golfo no início da década de 1990, e, com uma estrutura reformulada de forças e comandos, a OTAN pôde se envolver na dinâmica dos conflitos no território da antiga Iugoslávia (RIBEIRO, 2011, p.2-3).

A adoção de um novo Conceito Estratégico em 1991, o início do processo de alargamento em meados da década de 1990 e a percepção de que o envolvimento da OTAN na Bósnia-Herzegovina efetivamente colocou um fim à guerra fez com que a organização fosse vista como dinâmica e bem sucedida, embora seu papel ainda não estivesse totalmente claro após o fim da Guerra Fria. Gradativamente, desenvolvia-se a perspectiva de uma organização que, de forma bem sucedida, estendia a mão a antigos adversários e contribuía para o estabelecimento e a consolidação da democracia nas Europas Central e Oriental. A OTAN contribuiu para a implementação do Acordo de Paz de Dayton na Bósnia-Herzegovina, ao passo que a União Europeia e a ONU foram vistas como fracassadas nessa ocasião. A perspectiva retórica foi reforçada com a ação funcional na definição de um conjunto de estruturas com propósitos de socialização, como o Conselho de Cooperação do Atlântico Norte, a Parceria para a Paz, o Diálogo 


\section{Conjuntura Austral}

Mediterrânico $^{2}$ e os alargamentos. O foco nas parcerias e no alargamento teve o efeito positivo de desviar a atenção a muitas críticas à atuação da organização nos Bálcãs (FLOCKHART, 2011, p.35-36). Embora o resultado da operação tenha sido considerado um sucesso e a OTAN tenha sido parte de uma campanha fundamental para interromper uma limpeza étnica em Kosovo, a forma como o conflito foi iniciado e gerido mostrou divisões internas e destacou a lacuna nas capacidades de norteamericanos e europeus, resultando em falta de unidade transatlântica e recriminações mútuas (FLOCKHART \& KRISTENSEN, 2008, p.9).

Num contexto de tantas dificuldades, a capacidade de adaptação da OTAN ficou evidente no sexto Conceito Estratégico, aprovado nos cinquenta anos da organização em 1999, num momento em que ficam claros desafios como a alteração da configuração política europeia em face da formação de novos Estados no continente, o alargamento da OTAN para o Leste e a tendência de alocação de mais responsabilidades de segurança e defesa para a União Europeia. As tarefas primordiais da OTAN, de acordo com tal Conceito Estratégico, eram a segurança - por meio da gestão de crises e das parcerias que abriam espaço para intervenções expedicionárias -, a consulta, a dissuasão e defesa. O artigo 5 do Tratado de Washington abandonou a visão de "agressões contra o território" e passou a considerar "qualquer ameaça de agressão", enquanto desapareceu a tarefa de manutenção do equilíbrio estratégico na Europa. Seriam necessários à vitalidade da organização a preservação do elo transatlântico; a manutenção de capacidades militares efetivas; o desenvolvimento de uma Identidade Europeia de Segurança e Defesa; a prevenção de conflitos e a gestão de crises; o estabelecimento de parcerias e do diálogo; e o controle de armas, o desarmamento e a contraproliferação (RIBEIRO, 2011, p.3-4). Assim, a OTAN adotou uma definição de segurança mais abrangente e agregou à tradicional defesa a relevância de fatores políticos, econômicos, sociais e ambientais, além de identificar novos riscos como o terrorismo, o conflito étnico, as violações dos direitos humanos, a fragilidade econômica e a proliferação das armas de destruição em massa e dos seus vetores. $\mathrm{O}$ portfólio de tarefas fundamentais foi ampliado ao incluir segurança, consultas,

\footnotetext{
${ }^{2}$ O Diálogo Mediterrânico foi criado em 1994 para institucionalizar as relações da OTAN com Argélia, Tunísia, Marrocos, Mauritânia, Egito, Jordânia e Israel.
} 


\section{Conjuntura Austral}

dissuasão e defesa, além da gestão de crises e das parcerias a fim de reforçar a segurança e a estabilidade na região norte-atlântica. Para a execução de tais tarefas, os membros da organização poderiam recorrer a forças modernizadas que viabilizariam respostas no espectro total de operações. Eles poderiam combinar apropriadamente forças convencionais e nucleares para defesa coletiva, operações de apoio à paz e operações de resposta a crises (LEMOS \& EUGÉNIO, 2011, p.60-61). As forças eram estruturadas com os objetivos de alcançar capacidades militares e cumprir missões específicas, o que levou ao abandono do conceito de equilíbrio de forças, baseado na quantidade de unidades e meios. A estrutura de comandos também foi reorganizada: na Europa, vários comandos funcionais e centros combinados de operações aéreas ficaram subordinados a comandos conjuntos; nos EUA, a nova estrutura era responsável pela promoção e supervisão da transformação permanente das forças e capacidades da OTAN, particularmente por meio do treinamento e do desenvolvimento de conceitos e doutrina (RIBEIRO, 2011, p.4-5).

\section{O novo Conceito Estratégico da OTAN}

Os efeitos negativos da guerra em Kosovo relacionados à percepção de incompatibilidades operacionais e a falta de capacidades europeias de alta tecnologia criaram questionamentos acerca da capacidade de ação da OTAN. Tais questionamentos ainda foram alimentados pela falta de comprometimento com o multilateralismo pela administração Bush nos EUA. Entretanto, com os atentados terroristas de 11 de setembro de 2001, os membros europeus da OTAN evocaram o Artigo 5 do Tratado de Washington pela primeira vez na história da organização em apoio aos EUA. Embora tais eventos tivessem dado início a uma maior solidariedade europeia e a fortes declarações de unidade, as relações transatlânticas ficaram gradativamente abaladas após o início de 2002, o que culminou numa crise mais séria em 2003, quando a França, a Alemanha e a Bélgica recusaram-se a autorizar um planejamento militar avançado da OTAN para auxiliar a defesa da Turquia numa eventual guerra no Iraque. A forma mais assertiva e unilateral com a qual a administração Bush se colocava diante de uma série de situações simbolizou uma ruptura fundamental com a prática estabelecida de negociação e persuasão e a importância do uso contínuo da ação retórica para a 


\section{Conjuntura Austral}

reafirmação dos valores compartilhados e da coesão da organização, que se via privada de métodos testados de superação de crises regulares. Embora mudanças significativas no sistema internacional e as transformações dos padrões de ação funcional claramente apontassem para uma revisão do Conceito Estratégico aprovado em 1999, a falta de confiança e o fim virtual das práticas constantes de negociação fizeram com que a OTAN ficasse incapaz de implementar as revisões necessárias em seu Conceito Estratégico. Nesse sentido, ao longo da década de 2000, a OTAN ficou limitada na tomada de decisões estratégicas, embora tivesse conduzido algumas missões práticas ampliando sua ação funcional, mas sem ser capaz de garantir unidade por meio da ação retórica. Além disso, ao assumir o comando da missão no Afeganistão, a OTAN foi incapaz de construir uma perspectiva fortalecida sobre sua ação, enquanto a missão propriamente dita teve consequências negativas para algumas práticas da organização estabelecidas por longa data, como a partilha equilibrada de riscos (FLOCKHART, 2011, p.38-40). A cooperação prática associada à missão no Afeganistão revelou divisões e fraquezas na Aliança ao demonstrar quais membros estavam determinados a assumir sua parcela de responsabilidade por um conflito que se mostrou mais difícil do que fora antecipado (SHEA, 2010, p.20-21).

Tornavam-se gradativamente mais evidentes as razões pelas quais a OTAN precisava de uma recalibragem estratégica. Os aliados precisavam encontrar consenso em torno da legitimidade de uso da força militar em operações que não tivessem como propósito a autodefesa e, de forma extrema, mesmo sem um mandato explícito do Conselho de Segurança das Nações Unidas. Essa era uma das questões mais controversas que não tinham sido resolvidas no Conceito Estratégico de 1999 e que ganhou maior relevância com a ação dos EUA no Iraque em 2003 e a implementação da doutrina norte-americana de preempção durante a administração Bush. Se a OTAN aspirasse a lidar com o terrorismo e a proliferação de armas de destruição em massa, o momento de utilização e a legitimidade da força militar seria uma questão com a qual os aliados precisariam lidar. Além disso, a OTAN parecia focar amplamente nas operações correntes, mas não se dedicava tanto às crises potenciais. Uma série de prioridades precisavam ser definidas para que a organização preservasse sua relevância, em particular a natureza da defesa coletiva e a importância de redefinir seus instrumentos 


\section{Conjuntura Austral}

operacionais para fazer frente a novos desafios na área de segurança de maneira mais efetiva. Evidentemente, a defesa coletiva continuaria sendo o objetivo fundamental da Aliança, mas era preciso se definir mais especificamente o que ela significava quando cortes no suprimento de energia e o terrorismo cibernético pareciam ser ameaças cada vez mais presentes. Ademais, a OTAN deveria colocar suas relações com parceiros globais como a União Europeia e as Nações Unidas em outro patamar, esclarecendo seus direitos e obrigações mediante regras novas e transparentes (VAN HAM, 2008).

Em 2006, uma orientação política abrangente estabelecia prioridades para o desenvolvimento de capacidades específicas para um horizonte de dez a quinze anos, bem como para planejamento e troca de informações. Eventos imprevisíveis que demandavam a capacidade de se anteciparem requisitos potenciais eram admitidos, além da prontidão elevada e da flexibilidade para responder a transformações bruscas (RYNNING \& RINGSMOSE, 2009). Além da ameaça representada pelo terrorismo, as campanhas militares no Iraque e no Afeganistão, a crise entre Rússia e Geórgia, os ataques cibernéticos crescentes, a emergência de novas potências e os efeitos da crise financeira mundial levaram a OTAN a adotar um novo Conceito Estratégico em 2010. A proliferação de armas de destruição em massa e o terrorismo eram vistos em tal Conceito Estratégico como as principais ameaças, mas ele também considerava que o ambiente de segurança internacional poderia ser afetado pela instabilidade e conflitos fora das fronteiras da organização, que decorreriam do extremismo e dos tráficos de armas, narcóticos e pessoas. Ademais, os ciberataques poderiam ser dirigidos a organizações governamentais, empresas, redes de transportes e abastecimento ou outras infraestruturas críticas, e perturbações das rotas de comunicações, transportes e trânsito de pessoas e bens poderiam prejudicar o comércio internacional, a segurança energética e a prosperidade dos povos. As restrições de acesso ao espaço exterior, decorrentes do desenvolvimento de armas com laser e de tecnologias de guerra eletrônica, poderiam ter impacto no planejamento e nas operações da OTAN, bem como os riscos à saúde pública, a mudança do clima, a escassez de água e as crescentes necessidades energéticas (RIBEIRO, 2011, p.5-7). O novo Conceito Estratégico foi produzido diante de um momento em que os sinais de crise da organização eram evidentes. Em 2009, a chanceler alemã Angela Merkel e o presidente francês Nicolas Sarkozy tinham adiado a 


\section{Conjuntura Austral}

resposta ao apelo do presidente norte-americano Barack Obama para reforçar os contingentes desses Estados na Força Internacional de Assistência e Segurança (ISAF na sigla em inglês) no Afeganistão, uma missão que revelava divergências sérias entre os aliados (GASPAR, 2010, p.12).

O sétimo Conceito Estratégico da OTAN reafirmou a importância histórica da organização e a coesão dos membros, mas sinalizou a necessidade de novos parceiros e capacidades para enfrentar um cenário mundial em mudança constante, bem como a importância do alargamento da instituição e da continuidade de reformas visando a mais eficácia, eficiência e flexibilidade. A defesa coletiva continuava sendo listada como uma das principais tarefas da OTAN, em particular a defesa de territórios e populações dos Estados membros. A fim de garantir o conjunto de capacidades necessárias ao enfrentamento das novas ameaças, a organização intencionava cooperar com a Rússia no âmbito de defesas antimísseis, manter a liderança no desenvolvimento de tecnologias com impacto para segurança e defesa e desenvolver novas capacidades de prevenção, detecção, defesa e recuperação contra ciberataques, bem como capacidades para detectar e se defender de ataques terroristas e contribuir para a segurança energética, inclusive a proteção de infraestruturas críticas e linhas de abastecimento. A gestão de crises e conflitos para além das fronteiras da OTAN era uma segunda tarefa listada no Conceito, em esforços que envolviam a prevenção de conflitos, a intervenção em conflitos e a sua estabilização, bem como a ajuda para a reconstrução, e combinavam instrumentos políticos, civis e militares. Tal tarefa implicava o incremento da troca de informações, a melhoria das capacidades militares, o desenvolvimento de capacidades de natureza civil para uma melhor interação com parceiros civis - uma novidade na história da organização - e a ampliação e a intensificação das consultas políticas entre os membros da OTAN em todas as fases de desenvolvimento de uma crise. Finalmente, a terceira tarefa era a segurança cooperativa, primeiramente por meio da cooperação com Estados não-membros - como a parceria com a Rússia para o desenvolvimento de defesas antimísseis e a luta contra o terrorismo, a pirataria e o narcotráfico - e outras organizações internacionais - como a ONU e a União Europeia - com base na reciprocidade, no benefício e no respeito mútuos. A segurança cooperativa também poderia ser conquistada por meio da contribuição para a não-proliferação, o controle de 


\section{Conjuntura Austral}

armas e o desarmamento e do alargamento da OTAN, com a adesão de Estados democráticos europeus que estivessem em condições de observar os padrões da organização. Num contexto de crise econômico-financeira global, a utilização de recursos com eficiência e eficácia máximas apontava para a maximização da capacidade de projeção e de sustentação de forças nos teatros de operações; a busca de coerência máxima nos processos de planejamento - focando no desenvolvimento conjunto de capacidades necessárias e requisitos modernos - e a realização de um processo contínuo de reforma para a racionalização de estruturas e a melhoria dos métodos de trabalho (LEMOS \& EUGÉNIO, 2011, p.61-68).

Numa perspectiva geral, o novo Conceito Estratégico confirma que a OTAN manter-se-ia completamente comprometida com a defesa coletiva, mas que ela tinha completado a transição para uma organização com o interesse em olhar para além das suas próprias fronteiras territoriais. Ainda que fosse uma instituição regional de segurança, ela se mostrava mais ciente de que a segurança no século XXI era global. As ameaças endereçadas no Artigo 5 do Tratado de Washington poderiam ser agora vistas como quaisquer ameaças à segurança - em vez de ao território - dos Estados membros e à organização como um todo, independentemente da origem geográfica de um espectro maior de ameaças. A fim de capacitar a OTAN para lidar efetivamente com as novas ameaças, o Conceito Estratégico especificava que a organização precisaria desenvolver capacidades para responder a ciberataques e ameaças à infraestrutura crítica, bem como uma maior capacidade para realizar a defesa contra o terrorismo e agir ao longo do espectro da gestão de crises. O novo Conceito Estratégico comprometia a OTAN a desenvolver suas capacidades militares para operações expedicionárias e formar uma capacidade civil de gestão de crises, o que se configurava como um plano ambicioso num contexto de crise econômico-financeira. Tal Conceito Estratégico poderia alterar práticas estabelecidas por muito tempo e os padrões de ação da organização para orientações mais funcionais. Tais alterações incluíam a decisão de adotar um sistema de defesas antimísseis e simultaneamente desenvolver uma nova relação com a Rússia baseada na cooperação nessa área. Além disso, cabe destacar a decisão implícita de se trabalhar para uma revisão da postura nuclear da OTAN e a redução de armas nucleares norte-americanas baseadas na Europa; o estabelecimento de uma perspectiva abrangente 


\section{Conjuntura Austral}

que incluiria o objetivo de conectividade global; e o compromisso com a segurança por meio da gestão de crises (FLOCKHART, 2011, p.15-17).

\section{Continuidades e mudanças no novo Conceito Estratégico}

No Conceito Estratégico mais recente, existem traços de continuidade em relação aos anteriores aprovados desde o fim da Guerra Fria. Dentre elas, cabe citar a manutenção da missão fundamental de defesa coletiva, mesmo diante da falta de uma ameaça direta específica, a defesa da expansão geográfica da instituição e o lançamento de parcerias com Estados não-membros como instrumentos para a prevenção de conflitos e a maior flexibilidade de atuação para a própria OTAN. Além disso, é importante ressaltar a expansão da organização em termos conceituais, em particular o alargamento do conceito de segurança, com a incorporação do desafio de gestão de crises e a aplicação de uma perspectiva abrangente para operações, que acentuava o teor político das decisões em matéria de segurança. A reforma da estrutura e a reorganização permanentes na busca de maiores eficiência e partilha de responsabilidades entre os membros também eram um tema recorrente na agenda da OTAN, e o atual Conceito Estratégico apontava múltiplas dimensões desse processo, como a redução de estruturas em nível de quarteis generais e agências de segurança e defesa; a constituição de forças mais flexíveis, projetáveis e sustentáveis em teatros de operações; e a harmonização de processos de planejamento de defesa entre os Estados a fim de eliminar sobreposições. Era visível a ação de consultoria prestada pela organização para o desenvolvimento de capacidades endógenas que pudessem ser empregadas em benefício coletivo (LEMOS \& EUGÉNIO, 2011, p.69-71).

Dentre as inovações, é possível citar as novas bases para a cooperação com a Rússia, que apontam para uma cooperação estratégica aprofundada, com uma clara orientação a ser seguida a partir da identificação de aspectos de interesse mútuo. Tal cooperação tornaria possível a resolução de divergências visando à construção de credibilidade, confiança mútua, transparência e previsibilidade em áreas como as defesas antimísseis; a não-proliferação de armas de destruição em massa e seus vetores; o combate ao narcotráfico e a facilitação do trânsito para a sustentação da operação da OTAN no Afeganistão. O status de parceiro conferido a alguns Estados - com os quais 


\section{Conjuntura Austral}

as relações baseiam-se na reciprocidade e no benefício e respeito mútuos - também trouxe uma série de possibilidades para a organização, uma vez que os programas de parceria se estenderam a áreas com impacto direto na segurança norte-atlântica, como o Norte da África e o Oriente Médio. As parcerias com Estados de todo o mundo desenvolver-se-iam, segundo o novo Conceito Estratégico, de acordo com o diálogo político e a cooperação prática; a consulta sobre questões de segurança que suscitassem interesses recíprocos; e a participação dos parceiros na definição da estratégia e na tomada de decisões da OTAN em operações lideradas pela organização. No que diz respeito à parceria com as organizações internacionais, assumem uma importância particular aquelas desenvolvidas com a ONU e a União Europeia. Quanto à primeira, foi realçado o propósito de se aprofundarem o diálogo e a cooperação prática visando a superar dificuldades vistas em momentos como a guerra na antiga Iugoslávia. Quanto à segunda, o novo Conceito Estratégico enfatizava a necessidade de uma defesa europeia mais capaz e forte, apontando o desenvolvimento da cooperação prática entre OTAN e União Europeia em operações reais por meio da coordenação do planejamento e do apoio mútuo; o alargamento das consultas políticas nas esferas de interesse comum; e a cooperação mais profunda no desenvolvimento de capacidades para se evitarem duplicações e se ampliar a eficácia. No novo Conceito Estratégico, tais parcerias aparecem englobadas na noção de "segurança cooperativa" (RIBEIRO, 2011, p.10).

Já as defesas antimísseis passaram a ocupar um espaço ainda maior na defesa coletiva em face da proliferação de armas de destruição em massa e dos esforços de Estados como a Coreia do Norte e o Irã para a aquisição e/ou o desenvolvimento de ogivas nucleares e mísseis balísticos. Ademais, elas poderiam reforçar a presença dos EUA na Europa, bem como a coesão transatlântica. Para solucionar problemas como a eficácia duvidosa dos sistemas de defesas antimísseis no caso de ataques com grande número de ogivas, seria importante a resolução de questões fundamentais, como a transferência de tecnologia e informação de natureza militar à Rússia, o inimigo da organização por décadas. Entretanto, uma dificuldade para a cooperação entre a OTAN e a Rússia nas defesas antimísseis é a desconfiança da Rússia em relação à organização por conta dos conflitos de interesse no âmbito dos alargamentos da instituição. A defesa contra ciberataques também fora introduzida no novo Conceito Estratégico de forma 


\section{Conjuntura Austral}

explícita em termos de um processo de desenvolvimento de capacidades para detecção, análise, prevenção, defesa e recuperação em caso de ataques. A "perspectiva abrangente" que está na base do conceito de operações resulta da evidência, no contexto da guerra no Afeganistão e em outros teatros de operações, de que o instrumento militar é insuficiente para resolver conflitos contemporâneos. A nova modalidade de ação estratégica combina instrumentos político-econômicos, militares e de comunicação pública, associados à tarefa de gestão de crises. A busca de controle das linhas de comunicação marítima entre os membros da organização foi projetada para o nível global, inclusive com referências ao comércio internacional e à segurança energética em especial às redes de distribuição energética como oleodutos e gasodutos - a fim de se garantir a segurança contra atentados, sabotagens ou prejuízos causados por desastres naturais (LEMOS \& EUGÉNIO, 2011, p.72-74).

Embora o novo Conceito Estratégico apontasse para a preparação da OTAN no enfrentamento de um grande espectro de ameaças, devem ser feitas considerações sobre as novas tarefas e missões. A OTAN deveria conduzir tais missões somente após uma consideração cuidadosa e uma negociação ampliada a fim de garantir que todos os membros estivessem preparados para contribuir e após ter estabelecido que outros atores internacionais não estariam melhor preparados. Além disso, embora a OTAN estivesse ciente da necessidade de diplomacia pública e de construção de uma narrativa que fortalecesse as qualidades da organização para um público cético, a instituição deveria aprender com a União Europeia como ator na gestão de crises ao definir mais claramente os objetivos de suas missões e delinear parâmetros claros para delegar responsabilidade para outras organizações. A OTAN também deveria fortalecer as estruturas institucionais existentes para o diálogo e a negociação internos, bem como a arquitetura institucional específica das parcerias e dos programas de diálogo (FLOCKHART, 2011, p.6-7).

\section{Avanços e limitações no Novo Conceito Estratégico}

O novo Conceito Estratégico da OTAN foi ousado ao concordar em instalar um sistema de defesas antimísseis e convidar a Rússia a cooperar no novo sistema. Porém, ao mesmo tempo, o Conceito Estratégico compromete a organização ao objetivo de 


\section{Conjuntura Austral}

criar condições para um mundo livre de armas nucleares, embora também aponte que, enquanto houver armas nucleares no mundo, a OTAN manter-se-ia como uma aliança nuclear. $\mathrm{O}$ conjunto de áreas temáticas ligadas à postura nuclear, à postura de dissuasão, às defesas antimísseis, ao controle de armas e às relações com a Rússia está expresso numa forma branda e breve. Mesmo se levando em conta os outros documentos produzidos na cimeira de Lisboa - a Declaração de Lisboa e a declaração conjunta do Conselho OTAN-Rússia -, as questões relacionadas às posturas nuclear e de dissuasão são enigmáticas e caracterizadas por uma "ambiguidade construtiva", que se mostra útil na falta de amplo consenso na organização sobre as formas como proceder. A ambiguidade reflete o mínimo denominador comum no qual os membros da OTAN podem concordar enquanto dá ao secretário-geral da organização margem de manobra logo após a adoção do Conceito Estratégico. Ainda que as referências às defesas antimísseis e ao papel das armas nucleares sejam breves, uma observação mais precisa do Conceito Estratégico sugere que ele abra espaço para uma gradual e fundamental revisão da política nuclear e da estratégia de dissuasão da OTAN, o que pode pôr fim a práticas relacionadas à divisão de custos e riscos e aos truísmos defasados acerca do papel das armas nucleares na garantia da coesão entre os membros e na credibilidade da defesa coletiva. O Conceito Estratégico declara apoio implícito ao objetivo do presidente dos EUA Barack Obama de um mundo livre de armas nucleares. A organização se compromete a criar condições para um mundo sem armas nucleares, sendo que tais condições podem se referir à interligação entre a adoção das defesas antimísseis pela OTAN, uma relação renovada e cooperativa com a Rússia e as reduções - ou mesmo a eliminação - das armas nucleares não-estratégicas dos EUA estacionadas na Europa. Porém, o compromisso com um mundo livre de armas nucleares é de longo prazo, e a organização continuará sendo uma aliança nuclear enquanto houver armas nucleares no mundo. O novo Conceito Estratégico não especifica quais armas nucleares formarão a base de seu status nuclear, deixando aberta a possibilidade de que o status nuclear da OTAN possa ser baseado no futuro exclusivamente nos arsenais estratégicos dos EUA, do Reino Unido e da França. A organização aponta que buscará criar condições para mais reduções de armas nucleares estratégicas baseadas na Europa, o que está ligado às reservas de armas não-estratégicas da Rússia e ao controle de armas 


\section{Conjuntura Austral}

convencionais (FLOCKHART, 2011, p.17-18, 20-21). Entretanto, a manipulação política dos recursos energéticos, a interferência nas eleições presidenciais na Ucrânia, a ocupação da Crimeia, o ataque cibernético à Estônia e a intervenção na Geórgia confirmaram que a Rússia ainda pode trazer ameaças sérias aos membros da organização, enquanto, nos EUA e na Europa, acirra-se a divisão entre os defensores de uma política de firmeza para conter o poder russo e os partidários de uma parceria estratégica. A relevância das relações econômicas e a dependência energética apontariam para uma entente entre os Estados da União Europeia e a Rússia, mas as divergências políticas e a determinação em se preservar o status quo após o fim da Guerra Fria - em particular as independências da Ucrânia, de Belarus, da Moldávia e das três repúblicas caucasianas - têm o potencial de restringir as tendências conciliadoras (GASPAR, 2010, p.27-28).

A gestão de crises não era uma área temática nova para a OTAN; porém, o que foi surpreendente no novo Conceito Estratégico foi a elevação da gestão de crises ao nível de tarefa primordial, no patamar da defesa coletiva e da segurança cooperativa, mesmo num contexto em que essa tarefa foi difícil para a OTAN. Em vez de abandonar o papel da organização na gestão de crises após a experiência difícil no Afeganistão, o foco do novo Conceito Estratégico estava no aprendizado com a experiência passada e na sua transformação para conduzir melhores operações no futuro ao desenvolver uma "perspectiva abrangente", bem como ao coordenar e integrar os esforços de todos os atores internacionais mais relevantes. É difícil dizer que tal foco advinha de uma revelação impressionante, dada a necessidade evidente de cooperação e coordenação entre atores e perspectivas militares e civis. Entretanto, o fato de que a "perspectiva abrangente" aparecera no Conceito Estratégico indicava o reconhecimento implícito de que havia espaço para a melhoria nas tarefas de gestão de crises conduzidas até então, especialmente no Afeganistão, e podia ser visto como um claro reconhecimento de que apenas os meios militares não responderiam adequadamente a questões complexas e interconectadas envolvidas na gestão de crises. Ademais, a gestão eficiente de crises estava conectada à habilidade de OTAN de trabalhar melhor com outros atores internacionais, especialmente a União Europeia e a ONU. Sugeria-se assim que a expressão "perspectiva abrangente" cobria tanto diferentes perspectivas militares e civis 


\section{Conjuntura Austral}

para a solução de problemas como a cooperação multilateral ampliada entre atores internacionais distintos. Entretanto, integrar um conjunto tão vasto de áreas temáticas política, segurança, desenvolvimento, domínio da lei, direitos humanos e dimensões humanitárias - em missões internacionais trazia um considerável desafio relacionado à implementação. Ademais, o desenvolvimento de uma capacidade civil com a habilidade de planejar, empregar e coordenar capacidades militares e civis para a gestão de crises parece apontar que, para a OTAN, outras organizações podem não ser capazes ou muito determinadas a conduzir tal tarefa. O problema é que tal medida poderia levar à duplicação das capacidades civis da União Europeia e ser vista como uma expressão da falta de confiança no bloco (FLOCKHART, 2011, p.21-23).

As dificuldades nas relações entre a OTAN e a União Europeia transcendiam a questão do desenvolvimento de capacidades civis e antecediam o novo Conceito Estratégico. Formalmente, os EUA apoiavam as maiores autoconfiança e assertividade da União Europeia na política de segurança, mas temiam desafios à sua predominância. Já os Estados europeus tinham a determinação de alcançar mais autonomia nas áreas de segurança e defesa, mas temiam o abandono da Europa pelos EUA em face de mais autonomia da União Europeia. Em 1996, a Identidade Europeia de Segurança e Defesa - que seria criada no âmbito da OTAN - foi adotada com o objetivo de criar forças militares coerentes e efetivas capazes de operar sob o controle político e a direção estratégica da União da Europa Ocidental, sinalizando-se que os EUA aceitariam o desenvolvimento de uma defesa europeia fora da União Europeia. No fim da década de 1990, a União Europeia iniciou a Política Europeia de Segurança e Defesa como parte integrante da sua Política Externa e de Segurança Comum fora da OTAN, o que, na prática, desvalorizava a Identidade Europeia de Segurança e Defesa e diminuía a influência dos EUA sobre o papel europeu. Evidenciando-se a necessidade de maior cooperação intraeuropeia na área de defesa, a OTAN e a União Europeia assinaram os Acordos de Berlim Plus no início da década de 2000, a partir dos quais a União Europeia poderia ter acesso garantido aos recursos e às capacidades militares da OTAN para conduzir operações de gestão de crises, bem como aos sistemas de planejamento operacionais da OTAN. Entretanto, a União Europeia somente poderia atuar quando a OTAN no seu todo não se engajasse, de forma que os EUA tinham a possibilidade de 


\section{Conjuntura Austral}

vetar a disponibilização dos meios militares da OTAN para operações da União Europeia. Os Acordos de Berlim Plus funcionaram mal por conta do contato reduzido entre a OTAN e a União Europeia. O fortalecimento dessa relação está dependente de uma revitalização do relacionamento entre os EUA e a União Europeia, mas os contatos permanecem mais formais do que substanciais (DAEHNHARDT, 2010, p.108-113).

\section{Considerações finais}

Várias foram as mudanças trazidas pelos Conceitos Estratégicos da OTAN às orientações para as ações da organização ao longo da sua história, de forma que não se pode dizer que 2010 foi a primeira vez em que a instituição passou por modificações relevantes nas suas tarefas. Com o novo Conceito Estratégico, a OTAN procurou colocar um fim a duas décadas de indefinição sobre seus propósitos, uma vez que a sua ameaça primordial desapareceu e as atividades reais continuaram a se expandir, ainda que tenha mantido seu foco na ação militar no espaço norte-atlântico. O Conceito Estratégico de 2010 estabeleceu os princípios para a expansão das tarefas políticomilitares da organização, das suas fronteiras de atividade e também dos métodos, meios e funções. Por um lado, ele reafirma as tarefas de gestão de crises e defesa coletiva; por outro, aprimora tais tarefas. No que diz respeito à gestão de crises, a OTAN se mostrou mais disposta a realizar intervenções destinadas a ajudar a gerir crises, uma inovação incorporada após o aprendizado no Afeganistão de que a organização precisava acrescentar à prevenção de crises a estabilização pós-conflito e o apoio à reconstrução. Assim se explica o desenvolvimento de capacidades civis com o objetivo de facilitar sua cooperação com outras organizações melhor equipadas nesse campo, como a União Europeia, e permitir à OTAN atuar onde outros atores não sejam capazes. Já a defesa coletiva apareceu com novos conteúdo e peso. Em relação ao conteúdo, a organização estará atenta à defesa e à dissuasão de desafios emergentes de segurança que ameacem a segurança dos aliados individualmente ou de toda a instituição. Assim, confere-se liberdade de ação para que se considerem novas ameaças, em especial os ataques de mísseis balísticos por Estados periféricos e os ciberataques. Quanto ao peso, a defesa coletiva apareceu associada à segurança cooperativa, que valorizou a promoção da segurança internacional com recurso à cooperação no domínio dos armamentos e é 


\section{Conjuntura Austral}

fundada em parcerias existentes ou potenciais, num contexto de permanente reforma e transformação da OTAN para se fazer frente a um leque maior de ameaças com base em valores fundamentais e comuns. A OTAN sinaliza assim que assumirá também a função de promover arranjos de segurança em nível global que sejam benéficos aos interesses de seus membros. Tal função parece apontar para o maior desenvolvimento de parcerias globais de segurança, mas não tanto para um maior empenho da organização em se tornar a fornecedora global de segurança. Evidencia-se, assim, a importância das negociações em curso para a reorganização da estrutura de forças e comandos em face das reduções nos orçamentos de defesa dos membros da organização e os custos crescentes das operações da OTAN (RIBEIRO, 2011, p.13-15). Porém, cumpre lembrar que a parceria com a União Europeia ainda enfrenta obstáculos, em especial os referentes à relação da Turquia com a União Europeia por conta das suas dificuldades de adesão ao bloco e da questão cipriota. Ademais, cabe destacar a necessidade de se revisar o sentido de mecanismos, princípios, estruturas e conceitos que condicionam qualquer intervenção militar da União Europeia à declaração prévia da OTAN sobre o seu interesse em participar e não lidam com matérias que vão além das áreas tradicionais de segurança. Na parceria com a Rússia, um dos principais obstáculos continua sendo a consideração, pela Rússia, de que uma das principais ameaças à sua segurança é o alargamento da OTAN (RIBEIRO, 2011, p.14-15).

É importante que a OTAN aprenda com a experiência no Afeganistão, em especial a necessidade de definir claramente a missão antes que o engajamento ocorra. Na missão afegã, a OTAN se envolveu sem um objetivo claramente definido, sem uma estratégia claramente estudada ou uma estratégia claramente formulada de retirada ou de divisão de trabalho com outros atores internacionais relevantes. A OTAN poderia aprender com alguns aspectos da perspectiva da União Europeia para a gestão de crises. A maior parte das missões no âmbito da Política Comum de Segurança e Defesa da organização foi pequena, de duração limitada e com objetivos muito limitados, o que permitiu à União Europeia se retirar uma vez que tais objetivos tivessem sido atingidos. Nesse sentido, a OTAN precisa considerar mais seriamente seu objetivo de uma "perspectiva abrangente" para a gestão de crises ao garantir uma clara divisão de trabalho e de responsabilidade entre os atores envolvidos antes que o engajamento 


\section{Conjuntura Austral}

ocorra. Ademais, o objetivo expresso no Conceito Estratégico de 2010 acerca da expansão das relações da OTAN com atores internacionais relevantes deveria ser explorado, enquanto diferentes categorias de parcerias e outras formas de relacionamento poderiam ser trazidas para a discussão. Finalmente, uma maior ênfase na negociação e no diálogo dentro da própria OTAN poderia oferecer a ela um maior equilíbrio entre as ações funcionais e retóricas (FLOCKHART, 2011, p.44-46).

\section{REFERÊNCIAS:}

DAEHNHARDT, Patricia. O Novo Conceito Estratégico da NATO: as Relações com a União Europeia. Nação e Defesa, n.126, 2010, p.93-119.

FLOCKHART, Trine. After the strategic concept: towards a NATO version 3.0. DIIS Report, n.6, 2011, p.1-52.

FLOCKHART, Trine; KRISTENSEN, Kristian. NATO and Global Partnerships - to be Global or to Act Globally? DIIS Report, n.7, 2008, p.10-34.

GASPAR, Carlos. O Conceito Estratégico da Aliança Atlântica. Nação e Defesa, n.126, 2010, p.9-36.

LEMOS, Carlos Miguel Reis Silva de Oliveira e; EUGÉNIO, António Luís Beja. Uma reflexão sobre o Novo Conceito Estratégico da NATO. Boletim Ensino | Investigação, n.11, nov. 2011, p.55-79.

OTAN. Strategic Concepts. NATO website, 11 nov. 2014. Disponível em: $<$ http://www.nato.int/cps/en/natolive/topics_56626.htm>. Acesso em: 30 nov. 2014.

RIBEIRO, António da Silva. O conceito estratégico da NATO. Conferência oferecida na Academia de Marinha, 11 jan. 2011, p.1-19.

RYNNING, Sten; RINGSMOSE, Jens. Come Home, NATO?: the Atlantic Alliance's New Strategic Concept, DIIS Report, n.4, 2009, p.1-30.

SANTOS, José Alberto Loureiro dos. O Conceito Estratégico da NATO: Superar Contradições, Manter a Coesão. Nação e Defesa, n.126, 2010, p.37-46.

SHEA, Jamie. NATO at Sixty - and Beyond. In: AYBET, Gülnur; MOORE, Rebecca (Ed.) NATO in Search of a Vision. Washington, D.C.: Georgetown University Press, 2010, p.11-34. 


\section{Conjuntura Austral}

VAN HAM, Peter. NATO and the Madonna Curve: why a new Strategic Concept is vital. NATO Review, 2008. Disponível em: $<$ http://www.nato.int/docu/review/2008/03/ART5/EN/index.htm>. Acesso em: 3 dez. 2014.

Recebido em 12 de abril de 2015. Aprovado em 22 de Abril de 2015. 


\title{
Conjuntura Austral
}

\section{RESUMO}

O objetivo é explicar por que a OTAN adotou um novo Conceito Estratégico em 2010. $\mathrm{O}$ argumento central indica que a adoção de tal Conceito Estratégico está relacionada à necessidade de aprimoramento da defesa coletiva para se garantir o conjunto de capacidades necessárias ao enfrentamento das novas ameaças e ao fortalecimento das capacidades da organização para a gestão de crises e a segurança cooperativa, o que implicava o incremento da troca de informações, a melhoria das capacidades militares, o desenvolvimento de capacidades de natureza civil, a ampliação e a intensificação das consultas políticas entre os membros da OTAN e a maior cooperação com Estados nãomembros da organização e outras instituições internacionais. Além de propor a ampliação de capacidades para as ações funcionais, o novo Conceito Estratégico também ressalta a importância do uso contínuo da ação retórica para a reafirmação dos valores compartilhados e da coesão da organização.

Palavras Chave: OTAN; Conceito Estratégico; defesa coletiva, gestão de crises; segurança cooperativa;

\begin{abstract}
The aim is to explain why NATO adopted a new Strategic Concept in 2010. The central argument indicates that the adoption of the new Strategic Concept is related to the need to improve collective defense to ensure the set of capabilities needed to cope with new threats and the strengthening of the organization's capacity for crisis management and cooperative security, which implied the increased exchange of information, the improvement of military capabilities, the development of civilian capabilities, the expansion and intensification of political consultations among NATO members and the greater cooperation with non-members and other international institutions. In addition to proposing the expansion of capabilities for functional actions, the new Strategic Concept also highlights the importance of continuous use of rhetorical action to reaffirm the shared values and organizational cohesion.
\end{abstract}

Keywords: NATO; Strategic Concept; collective defense, crisis management; cooperative security 


\title{
Conjuntura Austral
}

\section{CONTINUIDADES DA POLÍTICA EXTERNA NORTE-AMERICANA NO PÓS-GUERRA FRIA: OS IMPERATIVOS DA DEMOCRACIA E DO MERCADO}

\section{Continuities of american foreign Policy in The Post- Cold War: The Imperatives of democracy And Market}

\author{
Leandro Carlos Dias Conde $e^{1}$
}

\section{Introdução}

Partimos, neste trabalho, do esquema de interpretação da Guerra Fria proposto por Noam Chomsky (2003), no qual o autor enfatiza a existência de duas leituras possíveis da ordem mundial na Guerra Fria: a da interpretação convencional e a que examina os fatos históricos. Ambas produzindo respostas bem distintas. A visão ortodoxa ou convencional está resumida pelo documento estadunidense fundamental da Guerra Fria, o National Security Council 68 (NSC-68) de abril de 1950, redigido pouco antes da Guerra da Coreia. A argumentação básica da visão ortodoxa é a que presa uma divisão maniqueísta do mundo entre o bem (Estados Unidos) e o mal (União Soviética), um mundo com dois lados opostos, em que não há arranjo nem acordo possível. A outra é a visão que está preocupada em examinar os fatos históricos, lançando luz sobre a retórica da política externa estadunidense, é a partir desta visão que este trabalho se estrutura.

Como avalia Lima (1996), formou-se uma verdadeira "indústria explicativa" sobre a ordem pós-Guerra Fria, com muitas análises e interpretações indicando várias agendas e criando modelos explicativos. Estas interpretações e hipóteses buscam caracterizar como a ordem mundial pós-Guerra Fria interage com o papel norteamericano, isto é, quais as agendas e estratégias da política externa dos Estados Unidos

\footnotetext{
${ }^{1}$ Mestrando em Ciência Política pelo Instituto de Estudos Sociais e Políticos da Universidade do Estado do Rio de Janeiro (IESP/UERJ) (leandrocdconde@gmail.com).
} 


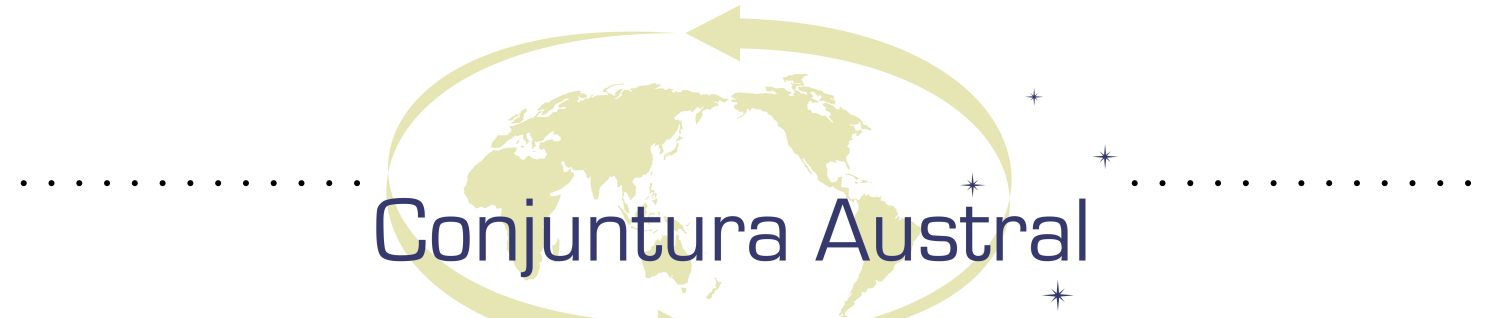

para a manutenção e expansão de seu poder. A avaliação empreendida por esses analistas, estrategistas e estudiosos ligados a universidades ou a governos produz cenários que reproduzem seus interesses e as estratégias para concretizá-los

As mais notórias interpretações e reflexões do novo momento histórico, repetidas e apresentadas pelos policymakers e intelectuais do establishment reproduzem muito do histórico debate entre internacionalistas ou isolacionistas, unilateralistas ou multilateralistas, conservadores ou liberais. Estes debates aparecem frequentemente nos discursos desde o fim da Guerra Fria ora um assumindo mais força que o outro e vice versa na orientação da política externa de Washington, contudo, pode-se dizer que os desacordos encontram-se nas estratégias, enquanto os objetivos seguem, de forma geral, uma continuidade histórica. Isso não é nada de novo para a política estadunidense, esta dinâmica parece ser estrutural na condução da política externa deste país.

Em linhas gerais, o discurso oficial, que dá forma à retórica do establishment norte-americano, no pós-1989, oscilou entre três tradições ${ }^{2}$ : o isolacionismo que preconizava que os EUA deveriam diminuir suas ações externas, reduzir seus gastos e voltarem-se as questões internas; os internacionalistas-multilateralistas que indicavam dificuldades para a manutenção da hegemonia dos EUA num mundo com novos atores e ameaças sem a renovação dos recursos de poder e a cooperação; e os internacionalistasunilaterais, que enxergam na ordem mundial unipolar do pós-1989 como momento de expansão da hegemonia, agindo unilateralmente contra qualquer ameaça à realização dos interesses nacionais, sendo a força militar recurso primordial. $\mathrm{O}$ embate entre essas duas últimas tradições é também conhecido como entre doves $x$ hawks, ou seja, as pombas (multilateralistas) contra os falcões (unilateralistas) (PECEQUILO, 2005).

O discurso oficial assume a predominância entre o campo isolacionista e o internacionalista em períodos históricos e administrações determinadas num duradouro debate entre os campos, que se reflete nas esferas de decisão da política externa norteamericana, a Casa Branca, mas também o Congresso, emerso numa miríade de grupos de interesses de todo o tipo e correntes políticas, o que faz com que a formulação da política externa norte-americana seja mais complexa do que aparenta num primeiro

\footnotetext{
${ }^{2}$ Essas três divisões não esgotam as possibilidades de classificação do período.
} 


\section{Conjuntura Austral}

olhar. Prender-se numa imagem de republicanos e democratas enquanto partidos coesos, no qual o último defende uma postura internacionalista e o segundo isolacionista é cair em simplismos, que não dão conta de romper o senso comum ao analisar a política externa dos Estados Unidos.

\section{Pós-Guerra Fria: Garantindo a Vitória}

A possibilidade real do "poder global", afirma Fiori (2008), surge com o fim da União Soviética, que coloca os Estados Unidos com a possibilidade, única na história, de conquistá-lo, isto é, um poder militar insuperável e não colonial, que é distinto dos impérios do passado. O poder global conquistado pelos EUA tem suas bases “[...] no controle de estruturas transnacionais, militares, financeiras, produtivas e ideológicas de alcance global, mas não suprime os Estados nacionais.” (FIORI, 2001, p. 63 apud FIORI, 2007, p. 94). A queda da União Soviética impulsiona o projeto de dominação neoliberal, no sentido de subordinar as economias nacionais ao capital global, mormente, norte-americano. Assim, aliada à liberdade para o recurso à força, o controle também seria exercido pela via econômica e da abertura das economias nacionais, reforçada pelas políticas do FMI e do Banco Mundial. Em resumo,

O projeto neoliberal é uma peça no grande projeto imperial dos Estados Unidos, que não se inicia com o término da Guerra Fria, muito menos com o desmonte da URSS. Estes eventos, obviamente, impactam na estratégia e produzem outras saídas, principalmente retóricas, mas que não mudam o curso imperial. Ora, se a ameaça soviete jazia no frio siberiano, era preciso lançar mão de novos inimigos que justificassem as intervenções e a "nobre" necessidade dos Estados Unidos no mundo. No período Reagan-Bush os terroristas internacionais ganham as páginas, nas administrações subsequentes no pós-Guerra Fria, os inimigos “[...] narcotraficantes hispânicos, os fundamentalistas islâmicos, árabes enlouquecidos e outras criações úteis", surgem e, paulatinamente, são exploradas ao máximo nos discursos oficiais, até que cumpram seu dever e consigam a anuência da população, buscando repetir a fórmula usual na qual “[...] o medo de algum Grande Demônio, seguido da admiração 


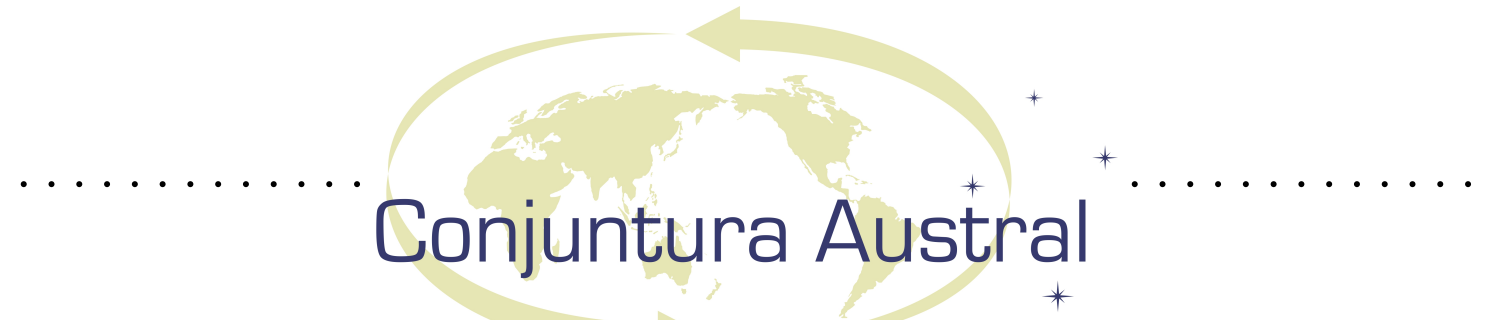

quando os nossos Grandes Líderes heroicamente o superam e marcham para novos triunfos." (CHOMSKY, 1993, p. 128-129).

De acordo com Fiori (2008), a doutrina estratégica para o século XXI toma forma e é anunciada pela primeira pelo presidente Bush I, em 1989, esta nova estratégia estava contida no documento "Defense Planning Guidance" (DPG) que vazara ao NYT, nela ressalta-se a "contenção preventiva universal", uma política de contenção voltada para qualquer potência regional que busque a primazia em sua região ou mesmo tencione conquistar o poder global. O presidente Bill Clinton dá sequência a esta doutrina, recorrendo a ela como justificativa de suas inúmeras intervenções militares, a despeito de sua retórica globalista e pacifista, diz-nos Fiori:

[...] na década de 1990 os Estados Unidos consolidaram uma infraestrutura de poder global, com cerca de 750 bases militares, 350 mil soldados e acordos de ajuda militar com cerca de 130 países, o que permitiu aos Estados Unidos, um controle quase monopólico dos oceanos e do espaço aéreo e sideral. (2008, p. 38-39).

O fim da Guerra Fria não teve uma nova "constituição do mundo" por parte das grandes potências, como aconteceu após os grandes conflitos no sistema internacional, desde Westfália em 1648 até Yalta, Potsdam e São Francisco em 1945. As tentativas existiram, segundo Fiori, foram duas, em Houston e outra em Dublin, em 1991, mas que perderam qualquer possibilidade de protagonismo ou força, diante da "[...] estrondosa demonstração de força militar americana na Guerra do Golfo [...]” (2007, p. 95). Desta forma, seja em Chomsky ou em Fiori, a insegurança e instabilidade do pós-Guerra Fria não decorrem do fim do comunismo e da ascensão de outras ameaças, mas, pelo contrário, do fim da situação bipolar anterior, na qual EUA e URSS se continham.

[...] entre 1945 e 1991, esta bipolarização tinha alcance mundial, e seu desaparecimento não deixou apenas um vácuo no campo do poder e dos valores internacionais; deixou uma incógnita absolutamente nova e radical, porque até então o sistema mundial ainda não tinha vivido a possibilidade real de constituição de um "império mundial" capaz de impor sua vontade política e seu arbítrio econômico sem enfrentar nenhum tipo de resistência política ou militar, como sempre aconteceu nas situações de "equilíbrio de poder", ou mesmo, nas "situações hegemônicas", dentro do núcleo central do sistema. (FIORI, 2007, p. 96). 


\section{Conjuntura Austral}

Claramente, avalia Fiori (2008), não se pode imputar exclusivamente aos Estados Unidos a conjuntura internacional deste início do século XXI, esta sofreu e sofre influência de outros atores, sejam estatais e não estatais, o master plan do império mundial norte-americano não se desenrola num mundo monolítico. Neste sentido, buscamos olhar para além da retórica do período pós-Guerra Fria, em que, segundo Chomsky (1993), os Estados Unidos vendem ao mundo a democracia e os direitos humanos aliada de doutrinas econômicas, quando são reais instrumentos de poder empregados por Washington. Assim, diz-nos Fiori, a expansão contínua do poder imperial norte-americano é essencial para “[...] entender a conjuntura geopolítica internacional, como a evolução da economia americana permanece essencial para qualquer análise do presente e do futuro da economia internacional.” (2008, p. 34).

\section{De Bretton Woods à Globalização.}

John Maynard Keynes e Dexter White buscavam construir um novo sistema monetário internacional para o pós-Segunda Guerra que tivesse como meta o desenvolvimento econômico internacional. Para isso, este sistema/regime deveria ter regras claras, previsíveis e que não privilegiasse nenhum país ou fosse manipulável. $\mathrm{O}$ ouro fora mantido como âncora do sistema, ou seja, como a terceira moeda e o dólar que já assumia grande proeminência como principal moeda usada no comércio internacional teve seu valor de troca fixado a partir do ouro, como as demais moedas. Assim, caberia a uma nova organização internacional, o Fundo Monetário Internacional (FMI) estabelecer cooperativamente entre os países, que faria com que os outros países aceitassem tal mudança no valor nominal de uma moeda, caso esta fosse para corrigir um "desequilíbrio fundamental na conta corrente de um país" (GOWAN, 2003). Porém, segundo Pereira (2012), logo após três anos das Conferências de Bretton Woods, o projeto de estabilidade monetária, livre comércio e liberdade crescente para os fluxos de capital sustentado pelos pilares FMI e BIRD ${ }^{3}$ foi escamoteado frente à busca dos

\footnotetext{
3 Banco Internacional para Reconstrução e Desenvolvimento, mais conhecido como Banco Mundial. (PEREIRA, 2012).
} 


\title{
Conjuntura Austral
}

Estados Unidos de manter a Europa sem influências comunistas, o que se produz numa doutrina de contenção naquele continente e o deslanche do Plano Marshall.

\begin{abstract}
O BIRD foi, em larga medida, uma criação dos EUA, que o forjou como parte de sua rede de poder infraestrutural externo. [...] A subida do banco à condição internacional relevante foi escorada, do ponto de vista político e financeiro, pelos EUA, que sempre foram o maior acionista e o membro mais influente. [...] mais do que qualquer outro grande acionista, os EUA se beneficiaram da ação do banco em termos econômicos e políticos, tanto no curto como no longo prazo. (PEREIRA, 2012, p. 418).
\end{abstract}

Este período de vigência de Bretton Woods, conhecido como a "idade de ouro" do capitalismo durante o pós-guerra, não pode ser compreendido como fruto espontâneo do mercado, pois como afirma Franklin Serrano, tratou-se de "[...] um arranjo internacional baseado em políticas econômicas altamente intervencionistas e inteiramente baseadas numa postura muito 'generosa' da potência capitalista dominante". (2004, p. 188). Os motivos de tais arranjos encontram-se intimamente ligados à Guerra Fria, na batalha entre o mundo de orientação capitalista e o de orientação socialista. No entanto, de acordo autor, ao longo da idade do ouro do capitalismo, os EUA, mesmo em meio a acumulados déficits da balança de pagamentos, velejava com bons ventos, tudo isto devido ao dólar ser a "moeda-chave" das relações comerciais, o que permitia à economia norte-americana pagar grande parte de seus déficits na sua própria moeda e não em ouro, soma-se a isto a saída e entrada de capitais se compensarem e serem feitas em dólar, o que garantia aos Estados Unidos que seu ouro não fosse mexido independentemente do déficit global de sua balança de pagamentos.

No entanto, para Fiori (2007), a hegemonia também começou a ruir por força do próprio sucesso do mecanismo de acumulação de poder e de riqueza que foi criado. Isto é, seus "sócios econômicos", sobretudo, Alemanha e Japão, mostravam cada vez mais interesse em competir por mercados e territórios com o irmão maior, os EUA, no sentido de expandir suas economias pujantes e que se encontravam na vanguarda da revolução técnico-científica do capitalismo: “[...] foi quando ocorreu a ruptura e o fim da "era do ouro" do crescimento capitalista, e terminou a "hegemonia mundial" 


\section{Conjuntura Austral}

exercida pelos Estados Unidos entre 1945 e 1973" (2007, p. 90). O que fez com que muitos vaticinassem que se tratava do declínio dos EUA enquanto superpotência e a emergência de novas potências que, para alguns, viriam a superar o poder norteamericano.

Encontra-se em outra importante característica de Bretton Woods, a "repressão financeira" internacional, que domava os grandes operadores privados internacionais impedindo-os de movimentar seus recursos livremente entre os países, um dos grandes imperativos para a ruptura com o sistema do pós-Segunda Guerra. Esta "repressão" implicava que os recursos de investimentos deveriam ter sua fonte nos próprios países e que os países definiriam as funções nas quais os especuladores financeiros poderiam atuar, assim, os países permaneciam com o direito de "dominar e definir" as atividades financeiras dentro do país, assim como os rumos do desenvolvimento econômico nacional.

A retórica da administração Nixon era que a justificativa para abandonar as estruturas de Bretton Woods estava no fato de que estas estruturas prendiam os EUA e davam liberdade para seus competidores ao favorecer o mercantilismo europeu e japonês, que mantendo suas moedas desvalorizadas tomavam mercados que antes eram dominados por norte-americanos e ameaçavam sua indústria, tratava-se do "Dilema de Nixon" (SERRANO, 2004). Frente aos problemas, os EUA, durante a administração Nixon, tinham outras saídas que não fossem a dissolução do regime de Bretton Woods, eles poderiam, diz-nos Gowan:

[...] empreender os ajustes econômicos necessários para colocar seu déficit sobre controle - cortando os gastos militares externos e reduzindo as importações, talvez através da deflação interna - ou poderiam desvalorizar o dólar frente ao ouro, assegurando dessa forma que os países superavitários pudessem comprar menos ouro com os seus dólares excedentes. (2003, p. $41)$.

Desta forma, a "crise do dólar" estava planejada e em pouco tempo aconteceria, suas bases já vinham sendo montadas desde a década de 1960, o ponto de recrudescimento ocorreu com a desvalorização do dólar e a abolição do sistema de 


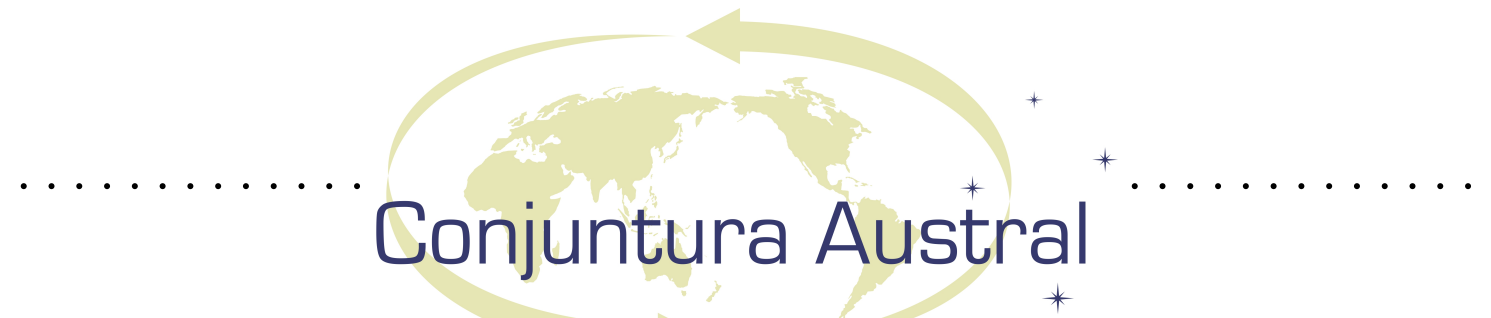

controle de capitais em 1974, diz-nos Fiori (2007, p. 93), “[...] (a) 'crise do dólar' não foi um acidente nem uma surpresa, nem muito menos uma derrota; foi um objetivo buscado de forma consciente e estratégica [...]”. Os Estados Unidos precisavam enfrentar as consequências de sua própria política expansiva, porém, mesmo dentro do establishment não havia consenso em torno das estratégias.

Outro resultado desta estratégia de Nixon, para Gowan, foi o êxito em alçar os bancos privados norte-americanos a outro patamar no sistema financeiro internacional, como veículos da reciclagem da enorme receita em dólar dos países produtores de petróleo, que, não tendo como absorver tais recursos em seus setores produtivos, recicla esse dinheiro em bancos ocidentais para outros países, esses são os chamados petrodólares.

Esta é uma situação única que conferiu aos Estados Unidos grandes liberdades no sistema monetário e financeiro internacional, a posição de moeda corrente internacional que o dólar assume, a partir deste momento, libera-os de restrições em relação à balança de pagamentos, comuns aos outros países. Gowan (2003) chama esta posição privilegiada de "senhoriagem do dólar", pois ela permite que os EUA gastem mais do que ganham no exterior e com isso possam, por exemplo, manter suas várias bases militares e postos avançados em outros países livre de restrição cambial, o que também favorece a atuação de suas transnacionais, assim como seus especuladores, pois a “[...] senhoriagem do dólar inclui dar ao sistema financeiro americano grandes vantagens como a principal fonte mundial de crédito (2003, p. 53)". Por exemplo, as variações no preço do dólar internacionalmente têm grandes efeitos no mundo, mas não produzem nenhuma consequência de grande adversidade aos Estados Unidos.

Portanto, das soluções buscadas para a crise da década de 1970, a escolhida foi a que levou à expansão do processo de "globalização", isto é, ao surgimento de um novo "regime econômico",", que Gowan chama de "Dollar-Wall Street Regime", dado pela

\footnotetext{
${ }^{4}$ Peter Gowan apropria-se da base da definição de regime de Stephen Krasner para caracterizar o padrão Dólar-Wall Street, mas modifica-a produzindo uma definição de regime que é signatária de Krasner, mas própria de Gowan, assim, para ele, "DWRS é um regime no sentido de um mecanismo internacional cujas estruturas e padrões governam as interações [...] ele desempenha o papel da estrutura
} 


\section{Conjuntura Austral}

sigla DWSR (Regime do dólar-Wall Street - RDWS). É preciso ter ciência de que a globalização só adquire a força que têm no pós-Guerra Fria devido à existência de um novo regime monetário e financeiro que produz sua dinâmica, que não surge fruto de espontaneísmos ou das forças invisíveis do mercado, mas tem sua existência em escolhas políticas tomadas conscientemente pelos Estados Unidos, num processo que tem seu pontapé inicial na década de 1960.

Vaticina Gowan:

As relações monetárias e financeiras internacionais são sempre produto tanto da economia quanto, sobretudo das escolhas dos países dirigentes. Estudos sobre a globalização que não explorem as dimensões políticas do regime monetário internacional que existiu desde 1973 deixarão de fora aspectos fundamentais da globalização. Esse sistema monetário internacional funcionou tanto como um "regime econômico" internacional quanto como um instrumento potencial de política econômica e de política de poder. (2003, p. 24-25).

As crises financeiras tornam-se cada vez mais constantes com o novo regime, mesmo que provocadas intencionalmente como os choques do petróleo. Gowan identifica como um aparente paradoxo o fato de as crises financeiras do Sul global não enfraquecerem o regime do DWS, mas fortalecê-lo, o que dá pela maneira como está integrado o sistema financeiro e monetário internacional. No primeiro momento, dada à existência da crise, os países têm uma enorme fuga de recursos, que se deslocam diretamente para Wall Street que se fortalece; precisam de divisas para pagar os serviços da dívida, que se dá através do dólar; e o uso do FMI para cobrir os riscos dos operadores financeiros somado ao poder que as instituições internacionais de crédito assumem sobre as finanças da economia nacional (GOWAN, 2003).

Por traz desses processos, os países periféricos foram se "financeirizando" como nunca antes, isto é, o capital financeiro foi dominando o processo produtivo desses países, e expandindo enormemente a sua influência política. Desta forma, os mercados internacionais passaram a ter grande importância na vida de todos os indivíduos desses países, mesmo que isso não esteja explícito. Qualquer que seja a reforma a ser feita nos

monetária e financeira que os países enfrentam em suas tentativas de lutar com uma ampla gama de situações-problema em política e economia, no nível internacional e interno (2003, p. 67-68)”. 


\section{Conjuntura Austral}

organismos multilaterais, precisamos levar em conta que estas são instituições que, genuinamente, servem ao poder e aos interesses de um grupo pequeno de países “aliados" dos Estados Unidos. Isto resulta em que:

[...] todo o sistema do FMI/Banco Mundial é programado para transferir os custos das jogadas de poder do mundo Atlântico para a maior parte da humanidade, que vive no Sul. [...] Pela intervenção do FMI/Banco Mundial, o país em crise torna-se mais tarde capaz de se reintegrar ao DWRS, mas dessa vez com grandes problemas de serviço da dívida e geralmente com uma estrutura financeira e econômica interna enfraquecida. Enquanto isso, o ambiente externo é tão volátil quanto nunca, e o país em questão tem mais probabilidade do que nunca de se deparar com uma nova crise financeira em um futuro não tão distante. (GOWAN, 2003, p. 66, 194).

De acordo com Atílio Boron (2010), a utilização de novos instrumentos de dominação extremamente sofisticados, os organismos e agências internacionais e multilaterais, constituem grande inovação do que ele chama de "novo imperialismo". São instituições a serviço de Washington, com destaque ao papel do FMI e do BIRD, que na forma de condicionantes de ajudas e empréstimos financeiros, forçam os países a empreenderem ajustes na sua economia, de modo a favorecerem o capital transnacional, mormente norte-americano.

$\mathrm{O}$ descolamento da hegemonia financeira dos Estados Unidos serve às suas outras dimensões de poder, é incorrer em equívoco analisar o projeto global norteamericano somente a luz de sua estratégia de segurança nacional ou dos dados econômicos, neste sentido, a separação liberal de economia e política dificulta a análise dos caminhos trilhados por Washington no pós-Guerra Fria. Afirmam Duménil e Lévy (2007, p. 145), que “[...] se os Estados Unidos não tivessem gozado desta posição dominante jamais teriam sido o agente desta globalização e nenhum país teria sido o vetor da nova ordem financeira".

Neste período, o capital financeiro retoma seu ciclo de expansão, sob a égide de uma política econômica neoliberal, centrada em ajustes econômicos e abertura dos mercados. As crises do capitalismo no regime pós-Bretton Woods permitem aos Estados Unidos reforçar o domínio do neoliberalismo, expandindo-o a territórios cada vez mais distantes e a Estados que antes das crises resistiam à onda neoliberal, essa foi 


\section{Conjuntura Austral}

uma agenda repetida por diversas vezes na década de 1990, com a administração Clinton aproveitando-se da posição única dos EUA. Para Duménil e Lévy (2007), Washington pouco se preocupou com o efeito devastador das crises financeiras nos Estados afetados, mas dedicou-se a expandir o domínio das finanças e a defender e favorecer seus interesses. Com este mecanismo, segundo os autores:

[...] a saída da crise e o reforço da hegemonia das finanças estadunidenses devem coincidir. É um aspecto singular desse duplo ou triplo jogo neoliberal: colocar-se como garantia da saída da crise, conduzir essa saída a sua maneira sem se preocupar em demasia com os danos que os demais sofrem, e fazer surgir uma ordem que garanta a preeminência dos interesses estadunidenses, em particular os financeiros. (2007, p. 153).

Desta forma, afirma Wood (2003, p. 160), “[...] o que se seguiu foi o período que chamamos de globalização, a internacionalização do capital, seus livres e rápidos movimentos e a especulação financeira mais depredadora em todo o mundo". O capital norte-americano precisava que as economias se ajustassem as suas novas necessidades, assim, as implicações destes ajustes foram severas no terceiro mundo, no que foi chamado de "Consenso de Washington", através do qual os Estados Unidos "forçaram" os países do terceiro mundo a passar por "ajustes estruturais" em suas economias a fim que elas se abrissem ao capital norte-americano, cabendo ao FMI e ao Banco Mundial ditar as condições e formas em que se dariam os ajustes. De acordo com Wood, o controle da economia global fortalecido pelos ajustes pós-Bretton Woods deram aos EUA a possibilidade de manejar as outras economias ao sabor das necessidades de capital interno, "manipulando as suas dívidas, as regras do comércio, a ajuda externa e a totalidade do sistema financeiro" (2003, p. 161).

Olhando além da fumaça da globalização, Duménil e Lévy (2007) asseveram que a internacionalização do capital e a globalização dos mercados - as barreiras à circulação de pessoas tende a aumentar exponencialmente com a globalização refletem o desequilíbrio de poder, mesmo no centro do capitalismo, com uma disparidade muito maior na relação desigual centro-periferia. "Ao contrário, a afirmação 


\section{Conjuntura Austral}

do neoliberalismo coincidiu com um renovado vigor da hegemonia dos Estados Unidos; em última instância, das finanças estadunidenses" (2007, p.144).

O projeto norte-americano no pós-Guerra Fria visava consolidar e "globalizar" o poder dos Estados Unidos, sobretudo durante a década de 1990, quando Washington deveria controlar os principais resultados econômicos e políticos mundiais no próximo século (GOWAN, 2003). Esta foi a década da globalização, e nas rédeas deste processo estava a administração Clinton na Casa Branca, era o turno democrata para levar adiante o projeto global dos Estados Unidos.

Durante a administração Clinton, tanto a palavra globalização quanto a palavra neoliberalismo tornaram-se de uso corrente no ocidente, contudo, como já evidenciado, estes não são fenômenos recentes, mas neste período assumiram a vanguarda do discurso econômico e tornaram-se armas da política externa norte-americana para atingir seus interesses econômicos e políticos em todo o globo. Na radicalização desta empreitada, os programas das organizações multilaterais são remodelados a fim de que sejam instrumentos fundamentais para a expansão da globalização e do neoliberalismo. Assim, as mudanças necessárias para que as economias nacionais abram-se ao capital global seriam implementadas pelos próprios países, que, por sua vez, seriam, também, os responsáveis por quaisquer efeitos negativos à sua população.

Uma série de organizações e foros internacionais foram criados na década de 1990, em que os EUA, como de costume, dominam o centro de poder. Dentre elas, a Apec (Cooperação Econômica Ásia-Pacífico) em 1993, o Nafta (Tratado de Livre Comércio da América do Norte) em 1994 e o aprofundamento das negociações do GATT (Acordo Geral de Tarifas e Comércio) que lança as bases para a OMC (Organização Mundial do Comércio).

O processo de globalização é apresentado como um fruto imparável do desenvolvimento técnico-científico, mas a realidade dos fatos é outra, o esforço de reduzir a globalização a imperativos de ordem puramente tecnológica e econômica têm como finalidade obnubilar o real papel dos EUA neste processo e como a globalização presta-se a seu projeto global. Portanto, segundo Ellen Wood (2003), devemos nos atentar para quais são os efeitos da globalização e quais não são, a despeito da retórica 


\section{Conjuntura Austral}

globalista do mainstream, do esforço deste para aceitar este processo como natural no desenvolvimento dos países. Por exemplo, o fluxo cada vez mais rápido do capital na economia global não significa necessariamente que os mercados estejam integrados.

Robert Cox (2007) salienta em sua análise os dois principais aspectos da Globalização, os quais ele chama de: organizações globais de produção e finanças globais. O primeiro, diz-nos Cox, "redes transnacionais complexas de produção que obtêm vários componentes do produto em lugares que oferecem as maiores vantagens em termos de custos, mercados, impostos e acesso ao trabalho apropriado [...]" (2007, p. 368). Quanto ao segundo, "em sua maior parte, um sistema não regulamentado de transações em dinheiro, crédito e ações".

\footnotetext{
Juntos, esses elementos constituem uma economia global, isto é, um espaço econômico que transcende todas as fronteiras dos países, e ainda coexiste com uma economia internacional baseada em transações que respeitam as fronteiras dos países e é regulamentada por acordos e práticas entre Estados. (Cox, 2007, p. 368).
}

Em decorrência da globalização, as sociedades nacionais estão se reestruturando e o mundo vê emergir uma "estrutura social global", diz-nos Cox (2007, p. 369), "A globalização é dirigida por uma classe transnacional de administradores que consiste em diversas frações (norte-americana, europeia, japonesa)". Este mundo da globalização é, também, o da produção "pós-fordista", isto é, as grandes linhas de produção em massa deram espaço a uma estrutura de produção descentralizada, que conta com diversas subsidiárias responsáveis por partes da produção espalhadas pelo globo e situadas nos locais em que a mão de obra é barata, os impostos são baixos e as margens de lucro elevadas, mas com o centro de controle permanecendo ainda situado no Estado de origem da empresa capitalista. Para Cox, "As economias de escala foram substituídas por economias de flexibilidade. [...] No processo de reestruturação da produção, o poder mudou dramaticamente do trabalho para o capital" (2007, p. 370).

Devido à globalização o estado retira-se de uma série de funções sociais, consideradas mal administradas e, por isso, entraves ao êxito econômico, segundo os ditames do neoliberalismo, ele também opta pela via da privatização livrando-se de 


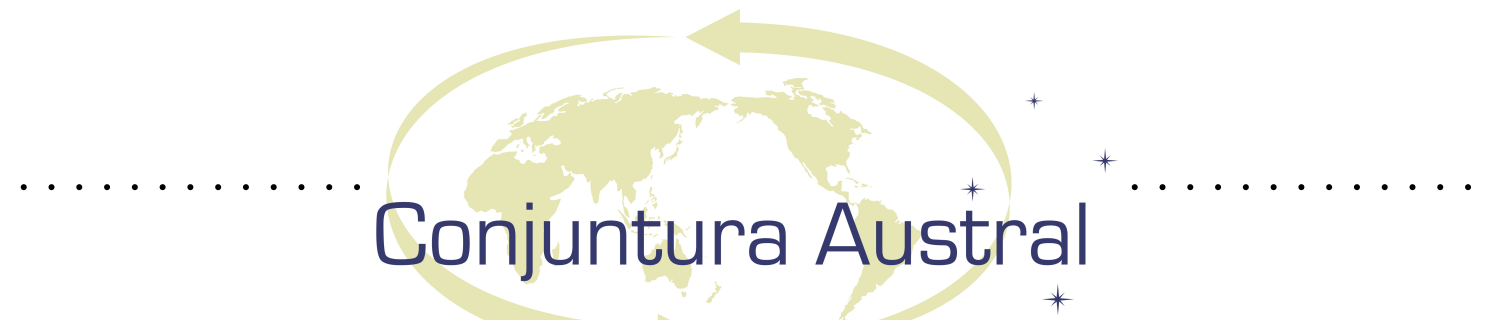

empresas públicas. Estas medidas, fruto do ajuste estrutural, impulsionadas diretamente pelo Banco Mundial, produzem a impressão de que realmente trata-se de uma retirada do estado, contudo o estado ainda é o único que oferece as condições para a acumulação de capital global, no centro do capitalismo e na periferia. Ganhou eco na opinião pública a ideia de que o estado, para sua eficiência, precisa reduzir suas tarefas a assumir uma dimensão mínima. Durante a onda neoliberal, sobretudo as décadas de 80 e 90 do século XX, muito se disse da "saída do estado" em prol do mercado, contudo, na primeira década do século XXI, o movimento seria outro, o do "retorno do estado".

O que suplanta as interpretações de que na globalização os Estados retiram-se frente às corporações transnacionais e as organizações internacionais. O sistema de múltiplos Estados nacionais está na base do capital global, isto é, este precisa dos Estados nacionais para realizarem em seus territórios as funções administrativas, legais e coercitivas que o sustentam, ou seja, o mundo global é, na verdade, o mundo dos Estados nacionais. Cada estado ou soberania local tem seus próprios interesses, o que torna o sistema de múltiplos Estados mais problemático ao novo imperialismo, assim, é necessário um poder militar global que mantenha todas as nações na linha cumprindo suas funções para a manutenção do sistema global (WOOD, 2003). Desta forma, obviamente, o estado não finda com a globalização, ele é o garantidor local, dentro das fronteiras nacionais, do êxito do capital global. O que vemos em "idas" e "retornos" do estado, diz-nos Vilas, é que em tempos de bonança o estado diminui frente à eficiência do mercado, mas a qualquer sinal de crise, o estado retorna como último salvador do sistema. É importante discutirmos a internacionalização do estado, fato que está à sombra da discussão sobre a retirada do estado no que seria um mundo globalizado, usando Poulantzas, diz-nos Panitch e Gindin,

[...] a tendência real que surgiu a partir da crise dos anos setenta foi a de "transformações internalizadas do próprio estado a fim de assumir a responsabilidade da internacionalização das funções públicas em benefício do capital". Portanto, os Estados-nação não estavam desaparecendo, mas somando responsabilidades. (2004, p. 43). 


\section{Conjuntura Austral}

Ao fim do desmonte do que era o sistema original de Bretton Woods, o capital norte-americano alçou o capitalismo como "[...] projeto global através do desenvolvimento de mecanismos formais e informais de coordenação internacional" (PANITCH; GINDIN, 2004, p. 46). “O consenso de Washington”, a agenda política e econômica norte-americana para o terceiro mundo, promovida pelo Banco Mundial, o Fundo Monetário Internacional e a Secretaria de Tesouro do governo dos Estados Unidos. O consenso tinha "[...] dois pressupostos teóricos: a economia neoclássica como ciência reitora da organização política e social, e a globalização como força devastadora a partir da qual se analisa as diversas problemáticas e realidades nacionais" (VILAS, 2010, p. 102). Nota-se o crescente fenômeno de "periferização do centro", os grandes bolsões de pobreza no centro do capitalismo, EUA, Europa Ocidental e Japão. O discurso da "globalização neoliberal", com suas receitas ortodoxas de ajustes monetários, corte de gastos sociais e elevação de impostos, gera o descontentamento generalizado na América Latina e nas demais regiões em desenvolvimento, o que repercute numa maior organização dos movimentos sociais e partidos de esquerda, a fim de reverter o quadro de desigualdade e miséria fruto do neoliberalismo.

Em síntese, nos Estados Unidos, a radicalização do neoliberalismo representou uma resposta política, em grande medida, ao que ainda restava das agências do New Deal e de empreender uma fatal derrota dos keynesianos, ou seja, empreender um desmonte dos avanços democráticos adquiridos pelas classes subalternas durante o período do ouro do capitalismo.

Como vimos, é preciso recuar ao início da década de 1980 para entendermos as crises do período e como elas contribuem para a continuidade e êxito do DWSR. Tratase das crises da dívida na América Latina e do leste e centro europeu, engatilhadas por Paul Volcker, presidente do FED (Banco Centro dos EUA), que tiveram consequências tamanhas a ponto de alguns economistas preverem o colapso do sistema bancário norteamericano. Contudo, como ressalta Gowan (2003), o êxito da crise foi a possibilidade ostensiva dos Estados Unidos, dada a fragilidade destes países, de usar de sua influência para favorecer a entrada de seus capitais na economia doméstica, nos regimes financeiros, e no mercado desses países. Foi durante a administração Reagan, que os 


\section{Conjuntura Austral}

planos de "ajustes estruturais" ganharam protagonismo, tornando função do FMI e do Banco Mundial empreendê-los na América Latina sob a retórica do "novo desenvolvimento global".

Seguindo a forte interferência nos programas das principais organizações multilaterais empreendida pelas administrações anteriores de Reagan e Bush, a administração Clinton radicalizou o uso destas organizações, colocando-as a serviço da estratégia norte-americana, voltadas a abrir as economias nacionais, e, especialmente, as do leste europeu e do sudeste da Ásia, mais resistentes ao agressivo avanço do capital norte-americano. A instrumentalização desses programas era apresentada pela retórica dominante como uma nova fase, o início de um "sistema cosmopolita de governo global", que faria esvanecer as rivalidades entre os países, através do domínio de leis internacionais que todos seriam submetidos (GOWAN, 2003).

Com a Estratégia de Segurança Nacional (NSS - National Strategy Security) apresentada em setembro de 2002, o governo Bush marcou a linha dura da política externa norte-americana contra o terrorismo que, supostamente, era uma ameaça real à hegemonia global dos Estados Unidos. Em conjunto com o NSS de 2002, o governo dos Estados Unidos lançou uma campanha de propaganda interna a fim de fabricar o apoio necessário para a Invasão ao Iraque, a ideia era ligar Saddam Hussein diretamente aos ataques de 11 de setembro e a intenção de cometer outros ataques aos EUA.

Muitos analistas afirmam que a NSS - 2002 do governo Bush representa uma grande ruptura na política externa norte-americana durante a Guerra Fria, baseada na contenção da União Soviética e a promoção da democracia liberal e da economia de mercado; e na década de 1990, com as administrações Bush I e Clinton, de reforço ao multilateralismo e do apelo globalista. Do ponto de vista da retórica, sim, há mudanças, mas que não impactam em descontinuidades significativas. Obviamente que a administração Bush II, ao tender à retórica extremista, ao desdém ao direito internacional a outros Estados, reforça o unilateralismo norte-americano, isto somente difere da retórica das administrações anteriores, pois: 


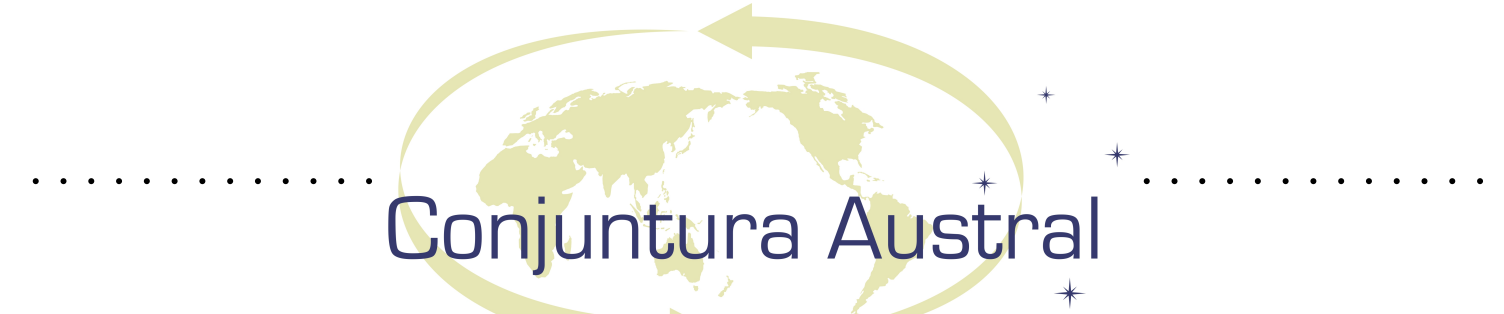

[...] não há nada de novo na convicção da equipe de Bush no que diz respeito ao principal objetivo da política exterior norte-americana que consiste em estabelecer a hegemonia sobre um sistema global de Estados mais ou menos soberanos, e que a superioridade militar massiva esteja na medula desse projeto. [...] a atual Doutrina Bush é uma manifestação peculiarmente extrema da antiga visão estratégica. Mas, por mais conotações destrutivas que assuma, tem suas raízes nas vastas ambições imperiais que guiaram a política exterior norte-americana desde a Segunda Guerra Mundial. (WOOD, 2003, p. 191-192).

Desta forma, a estratégia do governo Bush não deve ser vista como precursora de novas tendências ou mesmo algo de muito novo. Ao longo da história da política externa dos Estados Unidos, e mesmo na história mundial, a opção por discursos e ações beligerantes com riscos de produzirem mais conflitos foi algo corrente, pois o interesse estava sempre no fim último ou na manutenção deste, o poder global. O que há de novo, de acordo com Chomsky (2004), é que no período atual os perigos tornaram-se bem maiores e por isso, "A escolha entre hegemonia e sobrevivência poucas vezes foi exposta de modo tão evidente - se é que algum dia o foi (p.10)". Assim, se os EUA jogam com o futuro do planeta, seus movimentos e discursos tornam-se importantes e, obviamente, devemos estar atentos.

\section{Conclusão}

A Estratégia de Segurança Nacional avisa ao mundo que os Estados Unidos encontram-se mais do que nunca preparados e dispostos ao uso da força a fim de manter sua hegemonia, ou seja, seu domínio sobre o globo. A nova estratégia de segurança nacional apresenta-se como resposta ao terrorismo transnacional e os novos perigos do sistema internacional, ao contrário do que muitos pesquisadores apresentam, não é advento de um novo período no pós-Guerra Fria. O discurso da NSS incita o mundo a se preparar, seu aviso é, na verdade, uma grande ameaça a todos os países que tenham a intenção de fugir da cartilha de Washington. Ele acirra os ânimos externamente, mas também internamente, o terrorismo interno nunca esteve tão em alta nos Estados Unidos.

Sob este pretexto, de que tudo pode vir a se tornar um inimigo interno, e, por isso mesmo, da dificuldade de se combater um adversário com tais capacidades, Bush II 


\section{Conjuntura Austral}

chama os norte-americanos a estar em alerta, vigiarem e denunciarem qualquer indivíduo suspeito, montando um aparato de segurança que cada vez mais aproxima os Estados Unidos a um estado policial. A nova estratégia norte-americana, do combate ao terrorismo internacional, torna o sistema internacional ainda mais inseguro e instável.

A partir do momento que os Estados Unidos podem definir quem são seus inimigos e onde eles se encontram e agir de forma arbitrária, empreendendo ataques preventivos a qualquer estado que apoie ações terroristas ou mantenha bases em seu território, isto cria uma situação de guerra permanente. Portanto, precisamos ter claro que o projeto imperial já vinha sendo gestado desde muito tempo, como assinala Panitch e Gindin, “[...] a política explicitamente imperial que os estrategistas geopolíticos próximos ao partido Republicano já haviam desenhado, estava pronta e aguardando seu momento" (2004, p. 55). Para os autores, o empreendimento da guerra ao terror demonstra a imbricação do papel de mantenedor da ordem social global e do uso de seu poder militar a fim de proteger e promover os interesses nacionais norteamericanos no globo.

Isto quer dizer que enquanto as ameaças aos EUA forem vistas por estes últimos como um ataque ao capitalismo global em geral, o estado estadunidense terá cada vez menos paciência para fazer concessões que se interponham no caminho de sua conduta guiada por sua própria definição do interesse do capitalismo global e do uso ilimitado de seu poder estatal para resolver tais ameaças. (PANITCH; GINDIN, 2004, p. 55).

Primeiramente, capitalizando a comoção dos atentados, foi possível considerar a invasão ao Afeganistão como legítima defesa. Segundo Todorov (2010), a retórica oficial argumentava que, com a instalação dos militares norte-americanos no país e a implantação de um governo democrático, seria possível livrar aquele país das mãos dos terroristas. Realizada a invasão, o sucesso fora alardeado no ocidente, mas a retórica mostrou-se tremenda falácia e o resultado inverso se produziu, o sentimento de antiamericanismo nunca foi tão forte, a ocupação mostrou-se ineficaz, a manutenção dela e o aumento do contingente somente agrega mais instabilidade ao clima explosivo do país e que se estende a região. Diz-nos Todorov. 


\section{Conjuntura Austral}

O público ocidental retém os objetivos declarados da ocupação: apoio à democracia, defesa dos direitos humanos expulsão dos malfeitos terroristas. Já a população afegã retém a realidade vivida: bombardeios cegos, centros de detenção e de tortura (como Bagram, protótipo de Abu Ghraib), apoio a dirigentes corruptos. (2012, p. 65).

Portanto, a invasão ao Iraque não foi levada a cabo sob o pretexto do direito de ingerência, mas a partir da existência de armas de destruição em massa naquele país, contudo o princípio de ingerência estava presente no NSS-2002. O grande êxito da invasão ao Iraque também serviu para consagrar a nova norma do direito internacional, que está em consonância com a estratégia imperial norte-americana. Isto é, a estratégia dos Estados Unidos para o século XXI, apresentada no NSS de 2002, teve o Iraque como seu primeiro teste, que também serviu de alerta aos demais países do sistema interestatal, principalmente aqueles com que manifestam afãs autonomistas. Fica claro que a guerra do Iraque era necessária do ponto de vista dos EUA demonstrarem seu poderio no raiar do novo século, para Chomsky (2004, p. 27), “[...] uma demonstração de força para 'manter a credibilidade' aos olhos do mundo [...]".

\section{REFERÊNCIAS:}

BORON, Atílio A. A questão do imperialismo. In BORON, A.A. et al (org.). A teoria marxista hoje. Problemas e perspectivas. Buenos Aires: CLACSO, 2007.

CHOMSKY, Noam A. Ano 501 - A conquista continua. São Paulo: Scritta Editorial, 1993.

CHOMSKY, Noam A. A nova guerra contra o terror. São Paulo: Estudos Avançados 16 (44), 2002.

CHOMSKY, Noam A. Contendo a Democracia. Rio de Janeiro: Editora Record, 2003.

CHOMSKY, Noam A. O Império Americano: hegemonia ou sobrevivência. Rio de Janeiro: Elsevier, 2004.

CONDE, Leandro Carlos Dias. A Continuidade do Poder: Os Contornos da Política Externa dos Estados Unidos do Pós-Guerra Fria (1989-2008). Monografia 


\section{Conjuntura Austral}

(licenciatura) em Ciências Sociais. Instituto de Ciências Humanas e Sociais. Universidade Federal Rural do Rio de Janeiro, 2014.

COX, Robert W. Gramsci. Hegemonia e Relações Internacionais: Um Ensaio sobre o Método. In GILL, Stephen (Orgs). Gramsci, materialismo histórico e relações internacionais. Rio de Janeiro: Editora UFRJ, 2007.

DEFENSE PLANNING GUIDANCE, 1992. U.S. Strategy Plan Document. In The New York Times. Disponível em: < http://work.colum.edu/ amiller/wolfowitz1992.htm >. Acesso em: 25 Ago. 2013.

DUMÉNIL, Gérard; LÉVY, Dominique. Crisis y salida de la crisis: orden y desorden neoliberales. México, DF: Fondo de Cultura Económica, 2007.

FIORI, José Luís. O Poder Americano. Petrópolis, Rj: Vozes, 2007.

GOWAN, Peter. A roleta global: uma aposta Faustiana de Washington para a dominação do mundo. Rio de Janeiro: Editora Record, 2003.

LIMA, M. R. S. d. (1996). "Teses Equivocadas sobre a Ordem Mundial Pós-Guerra Fria.” Dados: Revista de Ciências Sociais 39(3): 393-421.

NATIONAL SECURITY COUNCIL. NSC-68: United States Objectives and Programs for National Security. A Report to the President Pursuant to the President's Directive of January 31, 1950. Disponível em: $<$ http://www.fas.org/irp/offdocs/nsc-hst/nsc-68.htm>. Acesso em: 15 Ago. 2013.

NATIONAL SECURITY STRATEGY OF THE UNITED STATES OF AMERICA 2002. Washington D.C., 17 de setembro, 2002. Disponível em: $<$ http://www.whitehouse.gov/nsc/nss.html > Acesso em: 25 Ago. 2013.

PANITCH, Leo; GINDIN, Sam. Capitalismo global e império norte-americano. In: Socialist Register. Buenos Aires: CLACSO, 2004.

PECEQUILO, Cristina Soreanu. A Política Externa dos EUA. Porto Alegre: Ed. UFRGS, 2aed, 2005.

PEREIRA, João Márcio Mendes, Banco Mundial: concepção, criação e primeiros anos (1942-1960). Belo Horizonte: Varia História, v. 28, nº 47, 2012.

SERRANO, Franklin. Relações de poder e a política macroeconômica americana, de Bretton Woods ao padrão dólar flexível. In: FIORI, J.L. (Org.) O poder americano. Petrópolis: Vozes, p. 179-222, 2004. 


\section{Conjuntura Austral}

TODOROV, Tzvetan. O medo dos bárbaros: para além do choque das civilizações. Petrópolis, RJ: Vozes, 2010.

TODOROV, Tzvetan. Os inimigos íntimos da democracia. São Paulo: Companhia das Letras, 2012.

VILAS, Carlos M. Las “idas" y "regressos" del Estado. Utopía y Práxis Latinoamericana. Año 15, no 43, 2010.

WOOD, Ellen Meiksins. El imperio del capital. Madrid: El Viejo Topo, 2003.

Recebido em10 de Janeiro de 2015. Aprovado em 23 de Abril de 2015. 


\title{
Conjuntura Austral
}

\section{RESUMO}

O presente trabalho busca discutir, ainda que de forma concisa, a política externa norteamericana no pós-Guerra Fria, fazendo um recorte histórico de 1989 a 2008. Assim como também lançar luz ao papel dos Estados Unidos na economia política internacional, em sua estratégia de manter e estender seu poder global.

Palavras Chave: Política externa; Estados Unidos; Pós-Guerra Fria;

\begin{abstract}
This paperdiscusses, albeit in a conciseway, the US foreignpolicy in thepost-Cold War, making a historical periodfrom 1989 to2008. Asalsoshed lighton the roleof the United States ininternational political economy, inits strategyto maintain and extendits globalpower.
\end{abstract}

Keywords: Foreign Policy; United States; Post-ColdWar; 
RESENHA

\section{Bookreview}

\section{CYBER CONFLICT: COMPETING NATIONAL PERSPECTIVES ${ }^{1}$}

\section{Thiago Correa Malafaia ${ }^{2}$}

How cybernetic constraints and considerations may potentially re-shape modern conflict is a pressing issue nowadays in many countries political agendas. If on the one hand more technology is being inserted in military forces, on the other this increased reliance on electronic interfaces only makes so that these forces be even more exposed to outside tempering in the form of actions specially targeting neuralgic systems to a country's civil/security apparatus.

There is extensive record of occurrences, some highly publicized, others not so much. Anyhow, this electronic "realm" of activity is bound to have lasting and stark effects on how war and conflict is going to be conducted in the near future. That is exactly the theme of Ventre's edited book. He and the various authors therein draw a reasonable picture about the state of readiness some countries have as to cyber matters. They assess nine case studies (Canada, Cuba, France, Greece, Italy, Japan, Singapore, Slovenia and South Africa) to show that each country responds to cyber menaces differently and that regional environments exert powerful influence, orienting, thusly, individual security postures when it comes to cyber issues.

The purpose of the book is to show how mostly non-centric countries, in terms of global security matters, behave as to the topic. It is evident, however, that one cannot comprehend the full picture without referring back to American, Chinese and Russian

\footnotetext{
${ }^{1}$ VENTRE, Daniel (eds.). Cyber Conflict: Competing National Perspectives; ISTE Ltd. and John Wiley \& Sons, Inc.; UK \& USA; 2012. ISBN: 978-1-84821-350-0.

${ }^{2}$ Mestre em Relações Internacionais (PUC-Minas); Doutorando em Relações Internacionais (PUCMinas); Bolsista CAPES. (thiagomalafaia@hotmail.com).
} 


\section{Conjuntura Austral}

actions and policies basically for these are the most active countries when it comes to this issue.

Countries' actions aside, the book also advances definitions for cyberspace and cyber-attacks, which are useful for their non-ambiguity. A cyberspace is a dimension encompassing the total of human activity, including combat. It is transversal to all other four dimensions: air, land, sea and space. However, it also has three layers to it: 1) that of physical infrastructure/hardware; 2) that of software/applications; and 3) that of cognition, affecting more directly the interface man-machine, or rather and bluntly put, the way man reacts to "inputs" delivered by machine (mal)functioning. Each of these layers is associated to a different type of action: the first, to netwar; the second, to cyberwar; and the third, to electronic warfare. Thus, cyberspace becomes a (virtual) medium through which attacks coming from one end of the "real" world can reach another of its "ends". This is exactly the definition of cyber-attack put forth by the authors - to use a virtual means to produce deleterious effects elsewhere in the "real" world.

Even though the authors disregard the main actors as to this particular global security issue, China, Russia, and the United States, which they agree, would complicate the analysis, the book brings powerful insights as to where global security matters are likely to be heading in the years to come. The book might be of interest to students and practioners of IR and Political Science alike.

Recebida dia 06 de janeiro de 2015. Aprovada em 23 de abril de 2015. 


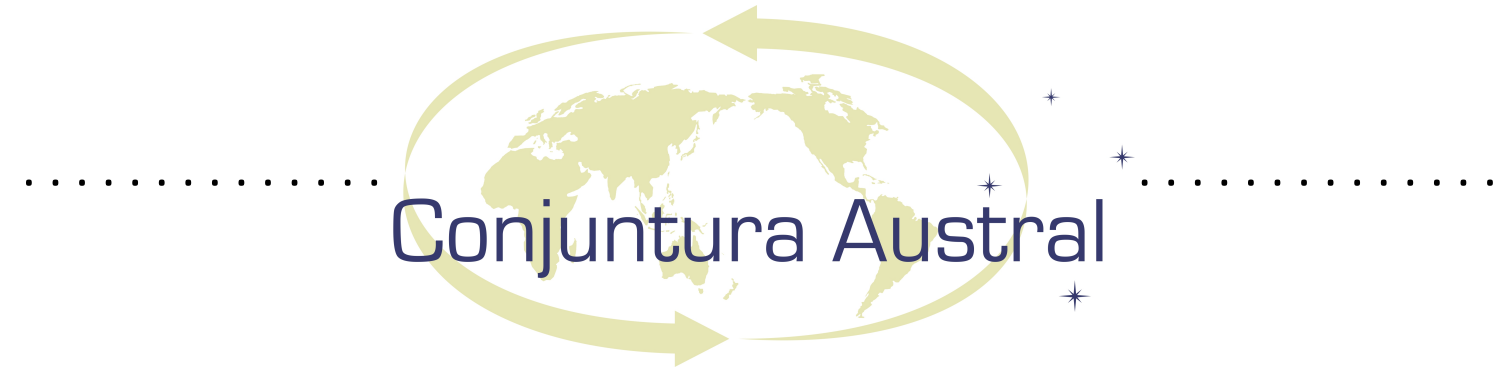

\section{NORMAS DE SUBMISSÃO}

\section{Diretrizes para Autores}

1. A revista CONJUNTURA AUSTRAL publica artigos científicos e resenhas bibliográficas;

2. A revista está dividida em três seções: Conjuntura; Pesquisa e Leitura (resenhas)

3. Os artigos de análise de conjuntura devem conter entre 8 mil e 20 mil caracteres (incluindo espaços); os artigos de pesquisa devem conter cerca de 35 mil caracteres (incluindo espaços); e as resenhas bibliográficas devem conter cerca de 5 mil caracteres (espaços inclusive);

4. As contribuições devem ser inéditas, e podem ser submetidas em português, inglês ou espanhol;

5. As contribuições não devem conter dados sobre o autor. Estes (nome completo, titulação, filiação institucional - com o nome completo da instituição - e e-mail para contato) devem ser inseridos nos respectivos campos da plataforma de submissão da revista;

6. O completo preenchimento, pelo(s) autor(es), do formulário de submissão do artigo é imprescindível;

7. Admite-se a publicação de estudantes de graduação, desde que em parceria com um professor orientador titulado, que constará como autor principal do trabalho.

8. No caso de resenhas bibliográficas, devem ser informados os dados completos e o ISBN da obra analisada;

9. As contribuições devem vir acompanhadas de: 3 palavras-chave em português e 3 key words em inglês; Título em português e em inglês; Resumo em português e Abstract em inglês, ambos com até 50 palavras. Caso o idioma de submissão seja diferente do português, as contribuições também devem apresentar 3 palavras-chave, Título e Resumo na língua original de elaboração do trabalho. Além de constarem no arquivo submetido para avaliação, estas informações devem ser inseridas, nos campos destinados a elas, no momento da submissão;

10. As contribuições deverão ser apresentadas em documento Word 97-2003 ou superior, em fonte Times New Roman, tamanho 12, espaço 1,5, sem espaçamento entre parágrafos;

11. As notas de rodapé restringem-se a esclarecimentos adicionais ao texto, não devendo conter referências bibliográficas;

12. As citações diretas devem seguir a norma ABNT 10520/2002: até três linhas no corpo do texto destacada por aspas; maior de três linhas com recuo de $4 \mathrm{~cm}$ do lado esquerdo, espaçamento simples e fonte tamanho 10 ;

13. As referências bibliográficas devem estar em ordem alfabética de sobrenome, e devem constar no final do trabalho, de acordo com o seguinte formato:

SOBRENOME, Nome. Título do livro: subtítulo. Cidade: Editora, Ano.

SOBRENOME, Nome; SOBRENOME, Nome. Título do Capítulo/Artigo. In: SOBRENOME, Nome; SOBRENOME, Nome. Título do livro: subtítulo do livro. Cap.X, p. xx-xx. Cidade: Editora, Ano.

SOBRENOME, Nome. Título do Artigo. Nome do Periódico. v.X, n.X, p. xx-xx, Ano. Disponível em: $<$ Link para o artigo $>$. Acesso em dia mês ano.

SOBRENOME, Nome. Título da tese acadêmica: subtítulo. Tese de Doutorado em (curso), Universidade de Brasília, Ano, ( $\mathrm{n}^{\circ}$ de páginas) p.

SOBRENOME, Nome. Título da notícia de jornal/revista. Nome do Jornal/revista. Cidade, dia mês. ano (da publicação da notícia). Disponível em: <link para a notícia $>$. Acesso em dia mês. ano.

14. Em caso de dúvidas a respeito da formatação das referências bibliográficas, utilizar a NBR 6023/2002 da ABNT;

15. Só serão encaminhadas para avaliação aquelas contribuições que estiverem de acordo com as normas estabelecidas pela revista.

16. Todas as submissões devem ser feitas através do site da revista : www.seer.ufrgs.br/ConjunturaAustral.

\section{Condições para submissão}

Como parte do processo de submissão, os autores são obrigados a verificar a conformidade da submissão em relação a todos os itens listados a seguir. As submissões que não estiverem de acordo com as normas serão devolvidas aos autores.

1. A contribuição é original e inédita, e não está sendo avaliada para publicação por outra revista; caso contrário, deve-se justificar em "Comentários ao Editor".

2. Os arquivos para submissão estão em formato Microsoft Word, OpenOffice ou RTF (desde que não ultrapassem 2MB)

3. URLs para as referências foram informadas quando necessário.

4. O texto está em espaço simples; usa uma fonte Times New Roman de 12-pontos; emprega itálico em vez de sublinhado (exceto em endereços URL); as figuras e tabelas estão inseridas no texto, não no final do documento, como anexos.

5. O texto segue os padrões de estilo e requisitos bibliográficos descritos em Diretrizes para Autores, na seção Sobre a Revista, no site www.seer.ufrgs.br/ConjunturaAustral.

6. A identificação de autoria do trabalho foi removida do arquivo e da opção Propriedades no Word, garantindo desta forma o critério de sigilo da revista, caso submetido para avaliação por pares (ex.: artigos), conforme instruções disponíveis em Assegurando a Avaliação Cega por Pares. 


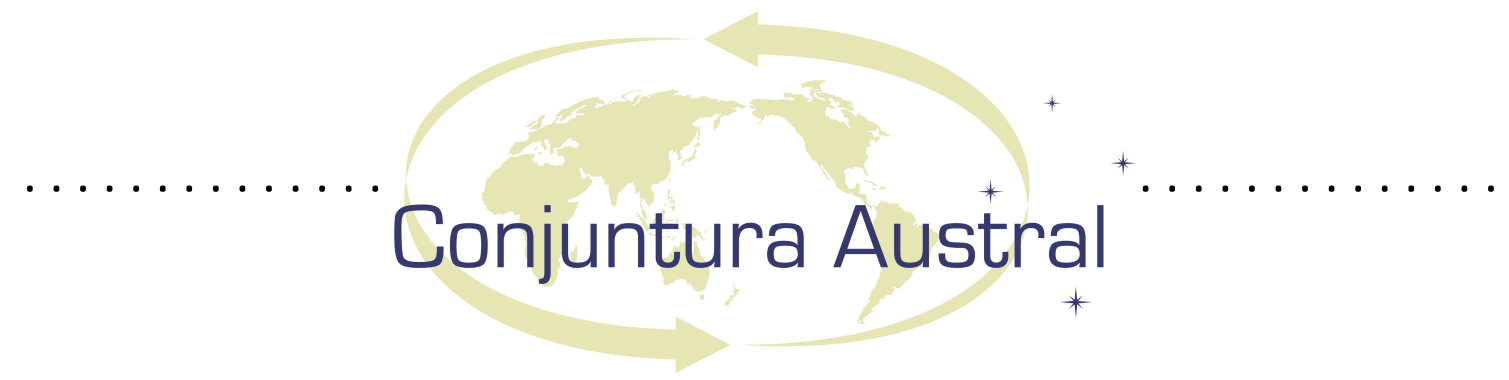

\section{SUBMISSION STANDARDS}

\section{Author Guidelines}

1. CONJUNTURA AUSTRAL journal publishes scientific articles and book reviews;

2. The journal is divided in three sections: Scenario Analysis; Research and Review (book review);

3. The scenario analysis should be between 8,000 and 20,000 characters (including spaces); research articles should contain about 35,000 characters (including spaces); and book reviews should contain about 5,000 characters (including spaces);

4. Contributions must be original, and can be submitted in Portuguese, English or Spanish;

5. The submitted files must not contain information about the author. Full name, title, institutional affiliation (with the full name of the institution) and e-mail must be inserted in the respective fields of the journal's submission platform;

6. It is mandatory to fill out all the information required on the submission form;

7. Publications of undergraduate students are accepted, as long as in partnership with an advisor professor, which will appear as the main author of the work;

8. Book reviews must contain the complete data and the ISBN of the analyzed work;

9. Contributions must be accompanied of: 3 keywords in Portuguese and 3 keywords in English; Title in English and in Portuguese; Abstract in English and in Portuguese, both with up to 50 words. If the original submission language is Spanish, contributions must also contain 3 keywords, Title and Abstract in that language. Moreover, the information referred to above must be inserted in the respective fields of the submission form.

10. Contributions must be submitted in a Word 97-2003 (or higher version) document, Times New Roman, font size 12, 1.5 spacing, without spaces between paragraphs;

11. The footnotes should be strictly of a substantive and complementary nature and should not contain references;

12. Direct quotations should follow the ABNT NBR 10520/2002 norm: if they contain up to three lines they must be distinguished by quotation marks; if they contain more than three lines they must be inserted in a different paragraph indented $4 \mathrm{~cm}$ on the left, with simple spacing and font size 10 ;

13. References should be in alphabetical order of surnames, and must appear at the end of work, according to the following format:

SURNAME, Name. Book title: subtitle. City: Publisher, Year.

SURNAME, Name; SURNAME, Name. Title Chapter/Article. In: SURNAME, Name; SURNAME, Name. Book title: book's subtitle. Chapter X, p. xx-xx. City: Publisher, Year.

SURNAME, Name. Article Title. Periodic Name. v.X, n.X, p. xx-xx, year. Available at: $<$ Link to article>. Access on day month year.

SURNAME, Name. Title of academic thesis: Subtitle. Doctoral Thesis in (course), University of Brasilia, year, (number of pages) p.

SURNAME, Name. Title of newspaper news / magazine. Newspaper/magazine name. City, day month year (of publication). Available at: <link to the news>. Access on day month year.

14. In case you have any questions regarding references formatting, refer to the ABNT NBR 6023/2002 norm;

15. Only contributions that fully comply with the Author Guidelines will be forwarded for the peer review process.

16. All the submissions should be made through the website: www.seer.ufrgs.br/ConjunturaAustral.

\section{Submission Preparation Checklist}

As part of the submission process, authors are required to check off their submission's compliance with all of the following items, and submissions may be returned to authors that do not adhere to these guidelines.

1. Contributions must be original, and shall not have been submitted for publication in another journal; otherwise, it must be justified in "Comments to the Editor".

2. Submitted files must be in Microsoft Word, OpenOffice or RTF (as long as their size is up to 2MB) format.

3. URLs must be informed in the references when necessary.

4. The text must be single-spaced; Times New Roman typeface 12 pt must be used for the body of the text; italic is to be used instead of underline (except in URL addresses); Figures and Tables must be embedded in the text.

5. The text must follow patterns of style and bibliographical requirements described in Authors Guidelines Author Guidelines, in the section "About the Journal", on the website: www.seer.ufrgs.br/ConjunturaAustral.

6. The identification of authorship of the work must be removed from the file and the Properties option in Word, thus ensuring the confidentiality criteria of the journal, if it is to be subjected to peer review (i.e. articles), accordingly with available instructions in "Ensuring Blind Peer Review". 


\section{Conjuntura Austral}

\section{INDEXADORES}

Os artigos publicados na Revista Conjuntura Austral estão sumarizados e indexados nos seguintes serviços internacionais (Articles appearing in this journal are abstracted and indexed in the following international services):

- Latindex

- Google Scholar

- $\quad$ Portal de Periódicos UFRGS

- Citas Latinoamericanas en Ciencias Sociales y Humanidades (CLASE)

- Ulrich Web

- Boletim Mundorama 